\title{
Safe to be open
}

Study on the protection of research data and recommendations for access and usage

Edited by Lucie Guibault and Andreas Wiebe

Universitätsverlag Göttingen 

Lucie Guibault and Andreas Wiebe (Eds.)

Safe to be open

This work is licensed under the Creative Commons License 4.0 "by".

(c)

SORERIGHIS RESERVED 
erschienen im Universitätsverlag Göttingen 2013 


\section{Safe to be open}

Study on the protection of

research data and recommendations

for access and usage

Edited by Lucie Guibault and AndreasWiebe

with contributions by

Nils Dietrich, Lucie Guibault, Thomas

Margoni, Krzysztof Siewicz, Gerald

Spindler and Andreas Wiebe

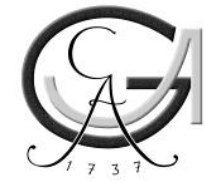

Universitätsverlag Göttingen 2013 


\section{Bibliographische Information der Deutschen Nationalbibliothek}

Die Deutsche Nationalbibliothek verzeichnet diese Publikation in der Deutschen Nationalbibliographie; detaillierte bibliographische Daten sind im Internet über $<$ http://dnb.ddb.de $>$ abrufbar.
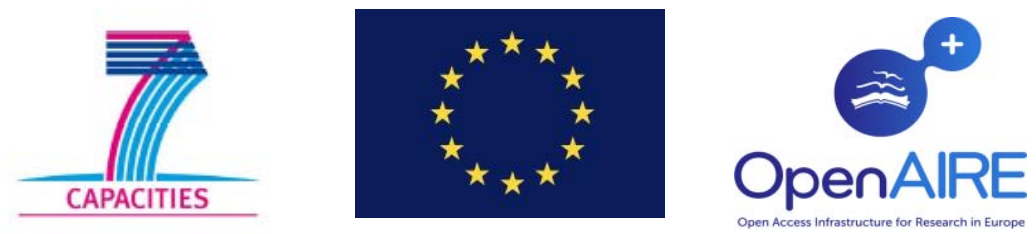

The OpenAIREplus project has received funding by the European Commission under grant agreement no. 283595.

\section{Contact}

Andreas Wiebe, Faculty of Law, University of Goettingen

e-mail: andreas.wiebe@jura.uni-goettingen.de

This work is protected by German Intellectual Property Right Law.

It is also available as an Open Access version through the publisher's homepage and the Online Catalogue of the State and University Library of Goettingen (http://www.sub.uni-goettingen.de). The conditions of the licence terms of the onlineversion apply.

Set and Layout: Nils Dietrich Language Editing: Carolyn Fox Cover design: Margo Bargheer Cover image: Lines Aapophysis Fractal Flame, Jon Zander, (Wikimedia Commons, cc-by-sa 2.5)

Reviewers: Walter Blocher, Axel Metzger and Birgit Schmidt

(C) 2013 Universitätsverlag Göttingen http://univerlag.uni-goettingen.de ISBN: 978-3-86395-147-4 


\section{Table of Contents}

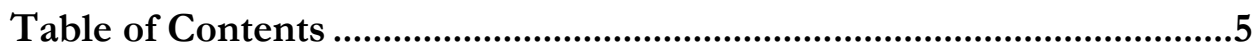

List of Abbreviations .................................................................

Summary ...............................................................................11

Nils Dietrich and Andreas Wiebe

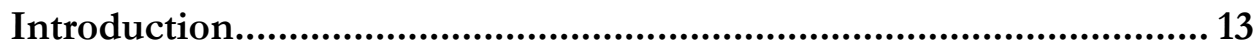

Lucie Guibault and Thomas Margoni

1. Definition of Research Data ........................................................... 17

Nils Dietrich and Andreas Wiebe

2. Possible forms of legal protection: An EU legal perspective........... 19

Nils Dietrich, Lucie Guibault, Thomas Margoni, Kraysztof Siewricz and Andreas Wiebe

2.1 Copyright ............................................................................................... 19

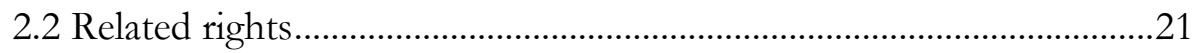

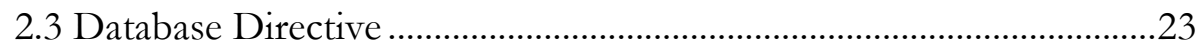

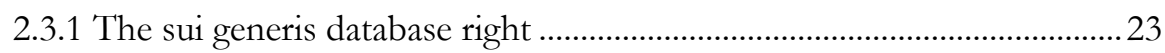

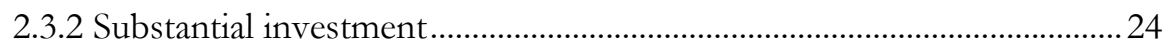

2.3.3 Substantiality: investment and infringement............................................... 26

2.3.4 Scope of protection....................................................................................... 31

2.3.5 The beneficiary of the protection ................................................................ 32

2.3.6 Exceptions and limitations to restricted acts ................................................33

2.3.7 SGDR and OpenAIREplus ...................................................................... 36

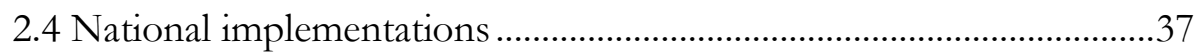

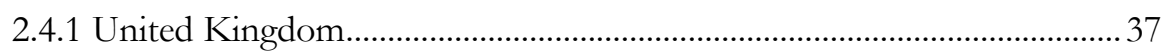

2.4.1.1 Protection as a copyright work .................................................. 37

2.4.1.2 Protection as databases ............................................................. 44

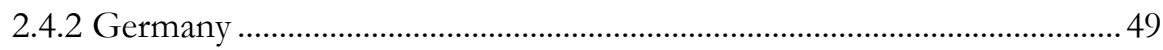

2.4.2.1 Protection as a copyright work ................................................. 49

2.4.2.2 Protection as databases ............................................................. 55 


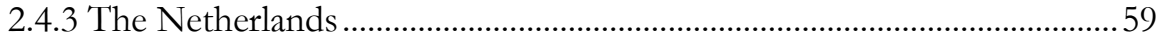

2.4.3.1 Protection under the Copyright Act ......................................59

2.4.3.2 Protection under the Database Act........................................64

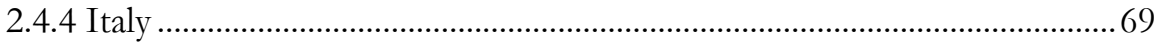

2.4.4.1 Protection under the Copyright Act ......................................69

2.4.4.2 Protection as databases ............................................................. 72

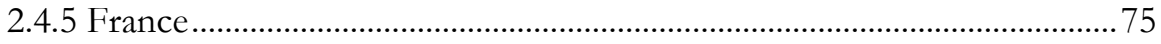

2.4.5.1 Protection under copyright law ............................................... 75

2.4.5.2 Protection as databases ........................................................... 76

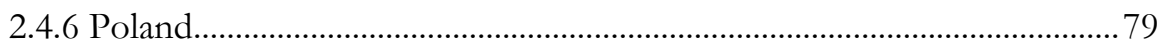

2.4.6.1 Protection as a copyright work ........................................... 79

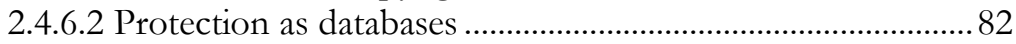

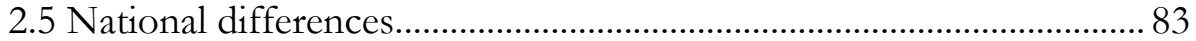

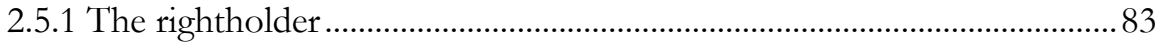

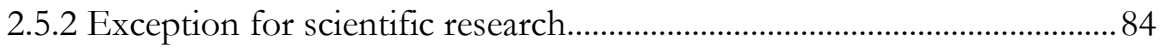

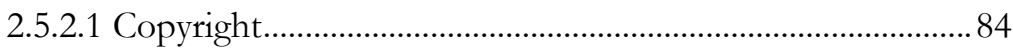

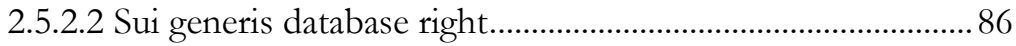

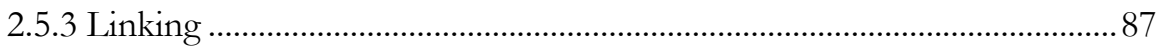

2.6 Know how/unfair competition/Patent ............................................ 88

\section{Scope of protection ...................................................................................93}

\section{Nils Dietrich and Andreas Wiebe}

3.1 Specific types of usage............................................................................ 93

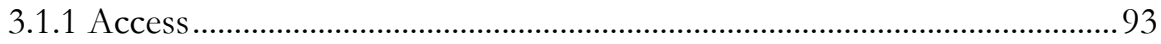

3.1.1.1 Copyright law.................................................................... 93

3.1.1.2 Sui generis protection as database...................................... 101

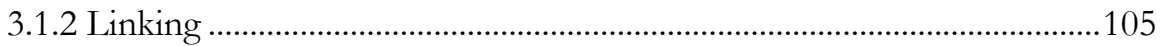

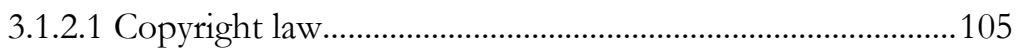

3.1.2.2 Sui generis protection as database .......................................106

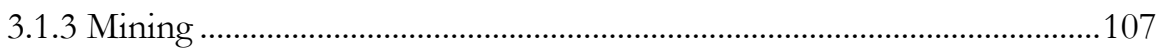

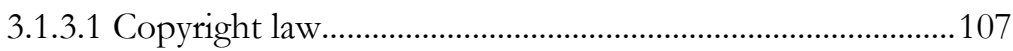

3.1.3.2 Sui generis protection as database.......................................109

3.1.4 Reuse in different contexts/modifications/enhancements ...................110

3.1.4.1 Copyright law....................................................................... 110

3.1.4.2 Sui generis protection as database ...................................... 112

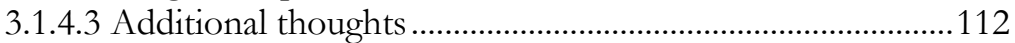


3.1.5 Results 113

3.1.5.1 Copyright ..............................................................................114

3.1.5.2 Sui generis Database right .......................................................114

3.2 Graphical overview and rights matrix ……………………………..... 116

3.3 "Legal Prototype" of e-infrastructure.................................................... 118

3.3.1 End user scenario A..................................................................................118

3.3.1.1 Which types of usage are relevant within the scenario? ....118

3.3.1.2 Do these types of usage infringe IP rights? .........................119

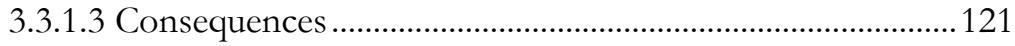

3.3.2 End user scenario B ...........................................................................122

3.3.2.1 Which types of usage are relevant within the scenario? ....122

3.3.2.2 Do these types of usage infringe IP rights? ......................... 122

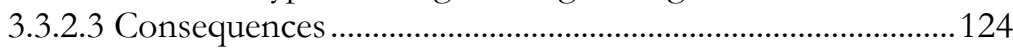

3.3.3 End user scenario C...............................................................................125

3.3.3.1 Which types of usage are relevant within the scenario? ....125

3.3.3.2 Do these types of usage infringe IP rights? ......................... 125

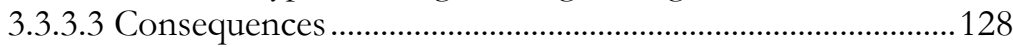

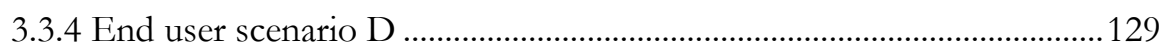

3.3.4.1 Which types of usage are relevant within the scenario? ....129

3.3.4.2 Do these types of usage infringe IP rights? ........................129

3.3.4.3 Consequences ............................................................................ 129

3.3.4.4 Additional thoughts ...............................................................129

3.3.5 Third-party provider scenario A ………………………………………....130

3.3.5.1 Which types of usage are relevant within the scenario? ....130

3.3.5.2 Do these types of usage infringe IP rights? ..........................131

3.3.5.3 Consequences .......................................................................... 132

3.3.6 Third-party provider scenario B .............................................................132

3.3.6.1 Which types of usage are relevant within the scenario? ....132

3.3.6.2 Do these types of usage infringe IP rights? ..........................132

3.3.6.3 Consequences ............................................................................. 134

3.3.7 Third-party provider scenario C ………………………………………....135

3.3.7.1 Which types of usage are relevant within the scenario? ....135

3.3.7.2 Do these types of usage infringe IP rights? ..........................135

3.3.7.3 Consequences .........................................................................136

3.3.8 Third-party provider scenario D...........................................................137

3.3.8.1 Which types of usage are relevant within the scenario? ....137

3.3.8.2 Do these types of usage infringe IP rights? .........................137

3.3.8.3 Consequences .........................................................................138 
3.3.9 Content provider registration and data processing scenario 139

3.3.9.1 Which types of usage are relevant within the scenario?.....139

3.3.9.2 Do these types of usage infringe IP rights? .........................139

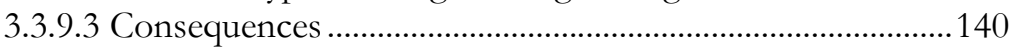

3.3.9.4 Additional thoughts ........................................................... 140

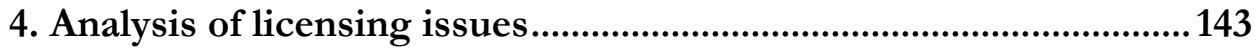

Lucie Guibault and Thomas Margoni

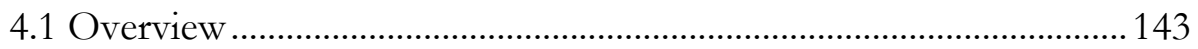

4.2 Contracts .......................................................................................... 148

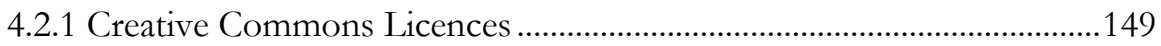

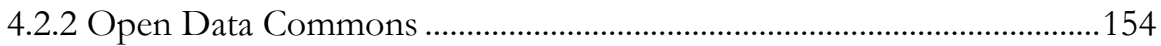

4.2.3 Digital Peer Publishing Licence (DPPL) …............................................159

5. Conclusions and Recommendations .................................................. 161

Lucie Guibault, Thomas Margoni and Gerald Spindler

5.1 Conclusions on the legal framework...................................................161

5.2 Recommendations to the European legislator ................................. 162

5.3 Recommendations to data- and e-infrastructure providers .............. 163 


\section{List of Abbreviations}

API

ASP

BGH

CC

CDPA 1988

Database Directive

DCA

DOI

EC

ECJ

EEA

$\mathrm{EU}$

Info Directive

IP

IPC

$\mathrm{NIH}$

$\mathrm{OA}$

OC

OD

PrAut

SGDR

Software Directive

TFEU application programming interface

Application Service Providing

German Federal Court of Justice (Bundesgerichtshof)

Creative Commons

UK Copyright, Design and Patent Act 1988

Directive 96/9/EC on the legal protection of databases

Dutch Copyright Act

Digital Object Identifier

European Community

European Court of Justice (the highest court of the Court of Justice of the European Union)

European Economic Area

European Union

Directive 2001/29/EC on the harmonisation of copyright and related rights in the information society

Intellectual Property

French Intellectual Property Code (Code de la Propriété Intellectuelle)

National Institute of Health

Open Access

Open Content

Open Data

Polish Copyright Act (ustawa z dnia 4 lutego 1994 r. o prawie autorskim i prawach pokrewnych)

sui generis database right

Directive 2009/24/EC on the legal protection of computer programs

Treaty on the Functioning of the European Union 
TRIPs

Ubd

UK

UrhG

VRE

WCT

WIPO

WPPT

WTO
W'TO Agreement on Trade Related Aspects of Intellectual Property Rights

Polish Database Act (ustawa z dnia 27 lipca 2001 r. o ochronie baz danych)

United Kingdom

German Copyright Law (Urheberrechtsgesetz)

virtual research environment

WIPO World Copyright Treaty

World Intellectual Property Organization

WIPO Performances and Phonograms Treaty

World Trade Organization 


\section{Summary}

This study is basically divided into four parts. Its objective is to examine the legal requirements for different kinds of usage of research data in an open access infrastructure, such as OpenAIREplus, which links them to publications.

Within the first part, the requirements for legal protection of research data are analysed. In the process, the existing legal framework regarding potentially relevant intellectual property (IP) rights is analysed from different perspectives: first from the general European perspective and subsequently from that of selected EU Member States (France, Germany, Italy, the Netherlands, Poland and the $\mathrm{UK})$.

It should be noted that the European legal framework is partly harmonised in the field of copyright and largely harmonised in the field of the sui generis database protection right by EU directives. Thus, the national regulations are quite similar in many respects. National differences are described following the section on national implementation in Chapter 2.5.

Despite European harmonisation, the perhaps surprising outcome of the analysis is that there are some areas of dis-harmonisation between the different Member States. One very significant example of dis-harmonisation is the "exception for scientific research" to the sui generis database right. It is not mandatory for this exception to be introduced into national legislation and it seems that every Member State has its own interpretation of the underlying directive. As it is drafted at the moment, the exception is to all intents and purposes useless.

Another area that causes difficulties is the question of who becomes the rightholder of the sui generis right in a database that is created by a public body or in the course of publicly funded research. Indeed it is far from clear. Some might say the research institution or the funding agency or both become the rightholder. But of the legal regimes under consideration in this study, the only jurisdiction with clear regulation on this matter is the Netherlands and it generally denies a public authority the right to exercise the exclusive database right.

Additionally, it is still unclear whether linking, or at least deep linking, should be seen as a relevant act of communication to the public. There are contradictory judgments at the level of the Member States. However, at least this question will soon be clarified in the scope of an actual reference to the European Court of Justice $^{1}$ (ECJ).

The second part of the study is dedicated to the scope of protection of the potentially relevant IP rights. First there is an analysis of whether different types of usage, such as linking, access or mining, infringe the different kinds of IP rights.

\footnotetext{
${ }^{1}$ The ECJ is the highest court of the Court of Justice of the European Union.
} 
Secondly, a "legal prototype of an e-infrastructure", based on selected usage scenarios that may occur during the use of e-infrastructures such as OpenAIREplus, is evaluated in more detail.

The main outcome of this second part is that by far the most important IP right in the context of e-infrastructures such as OpenAIREplus is the sui generis database right, and that it is very likely not possible to use all the described einfrastructure features without the consent of the respective rightholder(s).

The third part is an examination of some relevant licensing issues. Within this part of the study, different licence models are analysed in order to identify the licence that is best suited to the aim of Open Access, especially in the context of the infrastructure of OpenAIREplus. The result is that the upcoming CC License version 4.0 will probably be the one best suited to this kind of infrastructure.

Within the last part, some recommendations are given on improving the rights situation in relation to research data. To respond to the fact that the scientific research exception as presently formulated is rather useless, it is suggested that a new and broader mandatory research exception be introduced on a European level. To achieve legal interoperability of different databases and e-infrastructures, it is recommended that all of them should license their data under the upcoming CC License version 4.0. 


\section{Introduction}

Openness has become a common concept in a growing number of scientific and academic fields. Expressions such as Open Access (OA) or Open Content (OC) are often employed for publications of papers and research results, or are contained as conditions in tenders issued by a number of funding agencies. More recently the concept of Open Data (OD) is of growing interest in some fields, particularly those that produce large amounts of data - which are not usually protected by standard legal tools such as copyright. However, a thorough understanding of the meaning of Openness - especially its legal implications - is usually lacking.

Open Access, Public Access, Open Content, Open Data, Public Domain. All these terms are often employed to indicate that a given paper, repository or database does not fall under the traditional "closed" scheme of default copyright rules. However, the differences between all these terms are often largely ignored or misrepresented, especially when the scientist in question is not familiar with the law generally and copyright in particular - a very common situation in all scientific fields.

Public Access, for instance, is the term used by the National Institute of Health (NIH), the main US governmental funding agency for biomedical research, which is responsible for the funding of a large amount of academic research ${ }^{2}$. Since 2008 all publications that arise from NIH funds have to comply with the NIH Public Access Policy. The policy requires the final peer-reviewed paper to be deposited in PubMed Central, NIH's digital full-text archive, upon acceptance for publication, with an indication of when, within a period of 12 months (the socalled embargo period), the paper will become accessible to the general public ${ }^{3}$. More recently, thanks to a US government directive issued by the Office of Science and Technology Policy [Public Access Directive], all federal agencies with more than $\$ 100 \mathrm{~m}$ in research and development expenditure are required to develop plans to make the published results of federally funded research freely available to the public within one year of publication ${ }^{4}$. Additionally, the Fair Access to Science and Technology Research Act (FASTR) was introduced in the US Parliament

2 See http:// nih.gov (last accessed 06/2013).

3 "The Director of the National Institutes of Health shall require that all investigators funded by the NIH submit or have submitted for them to the National Library of Medicine's PubMed Central an electronic version of their final, peer-reviewed manuscripts upon acceptance for publication, to be made publicly available no later than 12 months after the official date of publication: Provided, That the NIH shall implement the public access policy in a manner consistent with copyright law", see Division G, Title II, Section 218 of PL 110-161 (Consolidated Appropriations Act, 2008), as confirmed by Division F, Section 217 of PL 111-8 (Omnibus Appropriations Act, 2009); for references see http://publicaccess.nih.gov/policy.htm (last accessed 06/2013).

${ }^{4}$ See http://www.whitehouse.gov/blog/2013/02/22/expanding-public-access-results-federallyfunded-research (last accessed 06/2013) with direct links to the Directive. 
at the beginning of 2013. If passed, such a bill would back up the goals of the Directive with the more robust structure of a legislative tool. The bill is similar to the Directive with small but significant differences in terms of the number and types of agencies covered, the embargo period, and the reference to publications (both) or also other research data (Directive) ${ }^{5}$.

This is indeed a great achievement that brings a huge contribution to the dissemination of knowledge produced with public funds (i.e. basically taxpayers' money). Nonetheless, this is Public Access, not Open Access as it covers only some of the requirements of the latter ${ }^{6}$.

Indeed, the NIH Public Access Policy does not provide any explicit right or implied licence to users. This means that PubMed Central users can merely download any paper they are interested in and read it ${ }^{7}$. And that is it. In fact, following such guidelines it is not possible to reproduce the paper (make copies), nor to redistribute the paper (post it on one's own website) nor to modify the paper, outside what is allowed by fair use or other exceptions or limitations to copyright law. All these rights remain within the author's domain (more often within the publisher's). The Directive specifically calls for agencies to implement measures to prevent the unauthorised mass redistribution of scholarly publications ${ }^{8}$. In consequence, users only enjoy Public Access, but not Open Access?.

Sometimes, an exclusive right to undertake activities not covered by applicable legislation, such as data mining or bulk downloading, is also created and enforced contractually. The same NIH PubMed Central Public Access Policy prohibits the use of crawlers or systematically downloading articles that are individually available for public access on their repositories, due to alleged copyright restrictions ${ }^{10}$.

${ }^{5}$ The text of the bill is available at http://doyle.house.gov/sites/dxoyle.house.gov/files/documents /2013\%2002\%2014\%20DOYLE\%20FASTR\%20FINAL.pdf (last accessed 06/2013).

${ }^{6}$ The term Open Access is discussed in more detail in Chapter 4.1.

${ }^{7}$ Interestingly the PubMed Central copyright notice prohibits bulk downloading of papers for copyright reasons: "Bulk downloading of articles from the main PMC web site, in any way, is prohibited because of copyright restrictions", available at http://www.ncbi.nlm.nih.gov/pmc/about/c opyright (last accessed 06/2013).

8 See Public Access Directive, sec. 3.

9 Indeed, PubMed Central offers a specific OpenAccess subset: http://www.ncbi.nlm.nih.gov/pmc /tools/openftlist (last accessed: 06/2013).

10 "Crawlers and other automated processes may NOT be used to systematically retrieve batches of articles from the PMC web site. Bulk downloading of articles from the main PMC web site, in any way, is prohibited because of copyright restrictions. PMC has two auxiliary services that may be used for automated retrieval and downloading of a special subset of articles from the PMC archive. These two services, the PMC OAI service and the PMC FTP service, are the only services that may be used for automated downloading of articles in PMC. See the PMC Open Access Subset for information about which articles are included in this special subset, and for links to the PMC OAI and FTP services. Do not use any other automated processes for bulk downloading, even if you are only retrieving articles from the PMC Open Access Subset. Articles that are available through the PMC OAI and FTP services are still protected by copyright but are distributed under a Creative Commons or similar licence that generally allows more liberal use 
The reason why a body committed to offering broader access to its funded research (although not Open Access) restricts activities nowadays so central to research (such as the mining of the data of a set of articles) beyond any legally sanctioned limits remains unclear, especially for those jurisdictions that do not know the existence of a right that protects non-original databases. Possible answers can take different angles, from lack of leadership and guidance at the policy level, to ignorance of practices in a given field, from the idea that "better to restrict access to it, one day it might be worth money", to T'TOs ${ }^{11}$ that uncritically opt for a standard reservation formula employed in the past for reasons yet to be demonstrated.

On 17 July 2012 the European Commission - showing leadership and policy guidance - published its Communication to the European Parliament and the Council entitled "Towards better access to scientific information: Boosting the benefits of public investments in research"12. As the Commission observes, "discussions of the scientific dissemination system have traditionally focused on access to scientific publications - journals and monographs. However, it is becoming increasingly important to improve access to research data (experimental results, observations and computer-generated information), which forms the basis for the quantitative analysis underpinning many scientific publications"13. The Commission believes that through more complete and wider access to scientific publications and data, the pace of innovation will accelerate and researchers will collaborate so that duplication of efforts will be avoided. Moreover, open research data will allow other researchers to build on previous research results, as it will allow involvement of citizens and society in the scientific process.

In the Communication the Commission makes explicit reference to open access models of publications and dissemination of research results (either Golden or Green Road, see below Chapter 4.1), and the reference is not only to access and use but most significantly to reuse of publications as well as research data.

The Communication marks an official new step on the road to open access to publicly funded research results in science and the humanities in Europe. Scientific publications are no longer the only elements of its open access policy: research data upon which publications are based must now also be made available to the public.

than a traditional copyrighted work. Please refer to the licence statement in each article for specific terms of use. The licence terms are not identical for all the articles", http://www.ncbi.nlm.nih.gov/pmc/about/copyright (last accessed 06/2013).

${ }^{11}$ TTO stands for Technology Transfer Office, a central asset nowadays for any public and private research enterprise, with the goal of managing and enhancing the value of investments and results in R\&D.

12 Brussels, 17.7.2012 COM (2012) 401 final.

13 Ibid., p. 3.s. 
As noble as the open access goal is, however, the expansion of the open access policy to publicly funded research data raises a number of legal and policy issues that are often distinct from those concerning the publication of scientific articles and monographs. Since open access to research data - rather than publications is a relatively new policy objective, less attention has been paid to the specific features of research data. An analysis of the legal status of such data, and on how to make it available under the correct licence terms, is therefore the subject of the following sections. 


\section{Definition of Research Data}

Research data is playing an ever increasing role in scholarly communication activities, and it is widely recognised that accessing a publication alongside related data is an effective way of making research outputs more visible and reused ${ }^{14}$.

The OpenAIREplus project has been focusing on ways to enhance the context of open access publication. OpenAIREplus aims to support the enhanced form of open scholarly communication and provide access to the research output of European funded projects and open access content from a network of institutional and disciplinary repositories, data centres, publishers and aggregated collections.

From a legal point of view, one of the very basic questions of this study is which kind of potentially protected data we are dealing with in the context of einfrastructures for publications and research data such as OpenAIREplus. The term "research data" in this context does not seem to be very helpful, since there is no common definition of what research data basically is. It seems rather that every author or research study in this context uses its own definition of the term.

Therefore, the term "research data" will not be strictly defined, but will include any kind of data produced in the course of scientific research, such as databases of raw data, tables, graphics, pictures or whatever else.

However, the aim of OpenAIREplus is to provide a service whereby users, via the OpenAIRE portal, can navigate a rich information space and get access to contextual information, for example associated datasets, citations, metrics or programme funding. As we will see, within the framework of the OpenAIREplus infrastructure, scientific databases comprise the most important kind of research data.

${ }^{14}$ http://www.driver-repository.eu/Enhanced-Publications.html (last accessed 08/2013). 



\section{Possible forms of legal protection: An EU legal perspective}

\subsection{Copyright}

In the EU, as well as in a total of 166 countries, the Berne Convention, first signed in 1886 and last amended in 1979, is the international instrument of reference for copyright protection ${ }^{15}$. With the original remit of offering a remedy for the lack of international recognition of national copyright protection, the Berne Convention evolved and set the stage for a minimum amount of protection that all members of the Berne Union should implement, together with basic principles such as those of national treatment and absence of formalities. More recently, the WIPO Copyright Treaty (WCT ${ }^{16}$ ) of 1996 and the Agreement on Trade Related Aspects of Intellectual Property Rights (TRIPs ${ }^{17}$ ) of 1994 have contributed to expand the Berne framework to "new" subject matters such as software and databases among others, and new forms of protection such as technological protection measures. Accordingly, the EU copyright law has developed around the framework established by those international treaties (of which all EU Member States are signatories, in the case of the WCT, and in the case of TRIPs the EU is a signatory member in its own right) and their principles are enshrined mainly in Directives $91 / 250 / \mathrm{EEC}$ on the legal protection of computer programs ${ }^{18}$, 92/100/EEC on rental and lending rights ${ }^{19}$, 93/83/EEC on satellite broadcasting and cable retransmission, 93/98/EEC on the term of protection, $96 / 9 / \mathrm{EC}$ on the legal protection of databases ${ }^{20}, 2001 / 29 / \mathrm{EC}$ on the harmonisation of copyright and related rights in the information society ${ }^{21}, 2001 / 84 / \mathrm{EC}$ on the resale right, and $2012 / 28 / \mathrm{EU}$ on certain permitted uses of orphan works.

\footnotetext{
${ }^{15}$ See the Berne Convention for the protection of literary and artistic works of 9 September 1886, last amended on 28 September 1979. The World Intellectual Property Organization (WIPO), the UN agency custodian of the administration of the Berne Convention, reports that as of 2013 the total number of signatory countries of the Berne Convention is 166, which is lower than the total number of WIPO participants (185), but considerably higher than the signatories of the WIPO Copyright Treaty (WCT) and of the WTO's TRIPs Agreement (reported to be 90 and 158 respectively, as of 2013); For figures consult http://www.wipo.int/treaties/en/statistics (last accessed 06/2013) and http://www.wto.org/english/thewto_e/whatis_e/tif_e/org6_e.ht m (last accessed 06/2013).

16 WCT signed 6 September 1952.

17 TRIPs signed 15 April 1994.

${ }^{18}$ New codified version: Directive 2009/24/EC (hereinafter also referred to as the Software Directive).

${ }^{19}$ New codified version: Directive 2006/115/EC (hereinafter also referred to as the Rental and Lending Directive).

${ }^{20}$ Hereinafter also referred to as the Database Directive.

${ }^{21}$ Hereinafter also referred to as the Info Directive.
} 
In addition to these eight directives, there is a proposal for a directive on collective management of copyright and related rights and multi-territorial licensing ${ }^{22}$.

The term "work of authorship", which is very important in the sphere of copyright protection, is not precisely defined by any of those directives, and the minimum levels of originality/creativity required to qualify for protection are present for only a few of the subject matters contained in the directives referred to above. However, the ECJ has recently applied such a parameter in a more horizontal way. In fact, the concept of originality in copyright law has been harmonised at the European level with respect to software ${ }^{23}$, databases ${ }^{24}$ and photographs ${ }^{25}$, and the same criterion was recently extended to all kinds of works through the interpretation of the ECJ ${ }^{26}$. The Infopaq decision ${ }^{27}$, as later followed in Bezpečnostni softwarová asociace $^{28}$ and other subsequent cases ${ }^{29}$, established that a work is original if it is the "author's own intellectual creation". In the Infopaq decision, the Court further clarified that the originality of a work must be assessed through its components:

Regarding the elements of such works covered by the protection, it should be observed that they consist of words which, considered in isolation, are not as such an intellectual creation of the author who employs them. It is only through the choice, sequence and combination of those words that the author may express his creativity in an original manner and achieve a result which is an intellectual creation ${ }^{30}$.

In the Football Dataco case, the Court added that:

the fact that the setting up of the database required, irrespective of the creation of the data which it contains, significant labour and skill of its author, as mentioned in section (c) of that same question, cannot as such justify the protection of it by copyright under Directive 96/9, if that labour and that skill do not express any originality in the selection or arrangement of that data ${ }^{31}$.

The Berne Convention, while silent on the level of creativity, offers in its Article 2 a non-exhaustive but quite detailed list of protected works, which includes:

\footnotetext{
22 See http://ec.europa.eu/internal_market/copyright/management/index_en.htm (last accessed 06/2013).

23 Article 1(3) Software Directive.

${ }^{24}$ Article 3(1) Database Directive.

25 Directive 2006/116/EC of the European Parliament and of the Council of 12 December 2006 on the term of protection of copyright and certain related rights (codified version), OJ L 372, 27.12.2006, pp. 12-18, Article 6.

${ }^{26}$ M.M.M. van Eechoud, 'Along the Road to Uniformity - Diverse Readings of the Court of Justice Judgments on Copyright Work', JIPITEC, 2012-1, pp. 60-80.

${ }_{27}$ ECJ Case C-5/08, Infopaq International A/S v Danske Dagblades Forening, [2009] ECDR 16.

${ }^{28}$ ECJ Case C-393/09, Bęppečnostní softwarová asociace v Kultusministerium, [2010] GRUR 2011, 220.

${ }^{29}$ ECJ Case C-604/10, Football Dataco Ltd et al v Yahoo! UK Ltd, [2012] GRUR 2012, 386.

${ }^{30}$ ECJ Case C-5/08, Infopaq International A/S v Danske Dagblades Forening, [2009] ECDR 16, para. 45.

${ }^{31}$ ECJ Case C-604/10, Football Dataco Ltd et al v Yahoo! UK Ltd, [2012] GRUR 2012, 386, para. 42.
} 
... every production in the literary, scientific and artistic domain, whatever may be the mode or form of its expression, such as books, pamphlets and other writings; lectures, addresses, sermons and other works of the same nature; ... photographic works to which are assimilated works expressed by a process analogous to photography; ... illustrations, maps, plans ${ }^{32}$.

Hence, copyright protects literary and scientific works such as articles, papers, and other types of publications in the scientific field. Whereas scientific publications virtually always attract copyright protection under the copyright laws of the Member States of the EU, the individual research data and the datasets containing them may not so easily fall under the copyright regime. Since copyright does not protect mere facts and ideas, but rather applies to the original expression of ideas, research data is not likely to qualify as protectable subject matter for lack of originality.

To be eligible for copyright protection, collections of data, tables and compilations must therefore show a sufficient degree of originality in their selection and/or ${ }^{33}$ arrangement ${ }^{34}$. Whether collections of scientific research data meet the criterion of originality is a question to be determined on a case-by-case basis. However, if the selection and arrangement of the contents of a scientific database are dictated by technical factors or imperatives of accuracy and exhaustiveness, then the author can exercise little to no creativity or originality in the choice, sequence and combination of the data in the collection. Scientific databases are therefore in most cases not likely to meet the threshold for copyright protection.

\subsection{Related rights}

Connected to copyright, but of a different legal nature, are the so-called neighbouring rights or related rights. They present a heterogeneous category inspired by the willingness to offer some sort of protection to activities that are not original/creative, but are somehow connected to original/creative activities. Their justification and scope vary significantly, not only between the rights themselves, but also with respect to the jurisdiction where they have found recognition, if any.

\footnotetext{
32 See Article 2(1) Berne Convention.

${ }^{33}$ Database copyright protection depends on originality with regard to the selection OR arrangement on the international level. Article 2, para. 5 Berne Convention (AND!) has been "revised" by Article 10, para. 2 TRIPs (OR!); a change reflected also in Article 5 WCT and Article 3(1) Database Directive.

${ }^{34}$ T.-E. Synodinou, 'The Foundations of the Concept of Work in European Copyright Law', in T.E. Synodinou (ed.), Codification of European Copyright Law - Challenges and Perspectives, The Hague, Kluwer Law International, 2012, pp. 93-113, p. 101.
} 
Traditionally, at the international level these rights are rooted in the Rome Convention ${ }^{35}$, which offers protection to performers, producers of phonograms, and broadcasting organisations. To these three "traditional" related rights, many others have been added over time, with wide variations regarding subject matter and geographical location.

Many of these related rights, whether pertaining to the traditional three or to a newer kind, are not usually triggered in the academic environment, as exemplified by the cases of performers' rights, phonograms producers' rights, fixation of the first master of a movie, or broadcasting signals rights, among others. However, one of these rights, present in the European legislation and left to each Member State to implement, is worth mentioning as it might be of some - though very limited - relevance. Some EU countries offer protection to scientific and critical editions of public domain works, that is, to the non-original rearrangement of outof-protection manuscripts. This protection is limited to the critical edition and does not extend to the critical apparatus. This rather peculiar form of protection is, however, limited to the case of sources, such as manuscripts, books, music compositions and similar, which, as a result of study by scholars, are re-proposed in a different form from the one previously thought of as the original ${ }^{36}$. However, mere research data (see above Chapter 1) could hardly fall into this category. The related right of critical editions can be of some relevance in very specific situations and therefore deserves to be mentioned. However, for the scope of this research, and in the light of its marginality, it will not be analysed any further.

Another related right that might be relevant in the academic environment could be connected to photographs in all those jurisdictions that distinguish the photographic work of art - protected by usual copyright rules - from mere photographs, which are protected by a related right whose scope is limited in comparison to copyright. In the present case, however, once again we are observing a specific protection afforded to material that could only potentially form part of research data, since diagrams and tables would not fit into such a category. An example could be shots taken of a seed over a specific time interval to observe its germination under specific temperature conditions. Such pictures, considering that angle, focus, shutter, speed, light, are fixed for all the samples taken, do not vary over time, and certainly do not aim at any artistic representation. Therefore, such pictures are not protected by copyright, but could represent the proper subject matter for mere photographs in those countries recognising such protection ${ }^{37}$.

\footnotetext{
35 See Rome Convention for the protection of Performers, Producers of Phonograms and Broadcasting Organisations, signed 26 October 1961.

36 See T. Margoni and M. Perry, 'Another example of EU copyright (dis)harmonization', Canadian Intellectual Property Review (2011) 27(1) p. 157.

${ }^{37}$ See for example the Italian Supreme Court, Corte di Cassazione 12-03-2004, n. 5089, requesting a personal and individual expression of the author, although the request of creativity remains at a minimum.
} 
There is, however, a right considered as related to copyright in some jurisdictions and as autonomous by others, that is specifically regulated at the EU level by a directive on database protection and that is of utmost relevance in our case: a right protecting non-original databases, the sui generis database right (SGDR).

\subsection{Database Directive}

The SGDR is a right created by the European legislator to offer protection to non-creative databases. The Database Directive provides for a double layer of protection to databases: (a) copyright when the selection or arrangement of the database represents its author's own intellectual creation - protection that covers only the database structure, not its content; and (b) the SGDR, which protects the content of the database when there has been a substantial investment in the obtaining, presentation or verification of the data, from acts of extraction (i.e. copying) and re-utilisation (i.e. redistribution, communication to the public, etc.) of the whole or a substantial part of the contents of such database. These two forms of protection are cumulative when the prerequisites for both are met $^{38}$.

Databases play a central role in the field of scientific research under analysis in this study and their legal protection will strongly influence the actions that scientists and researchers are allowed to take with the data currently available and with those subsequently created. Crucial for the achievements set forth in the Commission Communication and in general in any open access enterprise is the choice of the proper licences for research data.

\subsubsection{The sui generis database right}

As already mentioned, collections of scientific data may be protectable under the European SGDR. Through Article 7 of the Database Directive, as implemented in the legislation of the Member States, the maker of a database demonstrating a substantial investment (assessed qualitatively and/or quantitatively) in either the obtaining, verification or presentation of its contents has the exclusive right to prevent the extraction and/or re-utilisation of the whole or of a substantial part, evaluated qualitatively and/or quantitatively, of the contents of that database. Like copyright protection, the SGDR arises automatically, without any formal requirement, at the moment the database is completed or disclosed to the public.

In the context of scientific research, the wording of Article 7 of the Database Directive raises two main questions: first, does the scientific database show a substantial investment relating to the "obtaining, verification or presentation" of the content of that database? And secondly, should the answer to the first question be positive, does a research institution or the individual researcher qualify as the

${ }^{38}$ See Article 7(4) Database Directive. 
maker of the database, and therefore as a rights owner, if such database has been put together through public funding?

\subsubsection{Substantial investment}

With respect to the first question, the terminology of the Database Directive has given rise to numerous legal disputes before the national courts, which have led in turn to a number of references to the ECJ for preliminary rulings on the interpretation of the Directive's provisions. Note that so far disputes have almost exclusively involved commercial entities, with a public entity here and there, but as yet only one research or educational institution ${ }^{39}$.

The idea behind the Directive, as witnessed by a number of recitals ${ }^{40}$, is to reward considerable investments of substantial human, technical, professional and financial resources in the making of databases or, in the words of the ECJ, the promotion of the establishment of storage and processing systems for existing information ${ }^{41}$. In particular, the ECJ, deciding on the correct reading of the criteria for protection by Article 7, has given a narrow interpretation of the Directive's requirement that the database shows a substantial investment, assessed qualitatively or quantitatively, in either the obtaining, verification or presentation of its contents. In the landmark British Horseracing Board ${ }^{42}$ and Football Fixtures cases ${ }^{43}$, the Court ruled that the term "obtaining" excludes the costs incurred in the creation of new data (such as generating fixtures lists) from being considered relevant to satisfy the requirement of the substantial investment ${ }^{44}$. Paragraph 31 of the British Horseracing Board decision reads as follows:

[t] he expression investment in ... the obtaining ... of the contents of a database must ... be understood to refer to the resources used to seek out existing independent materials and collect them in the database, and not to the resources used for the creation as such of independent materials. The purpose of the protection by the sui generis right provided for by the directive is to promote the establishment of storage and processing systems for existing information and not the creation of materials capable of being collected subsequently in a database.

\footnotetext{
${ }^{39}$ See ECJ Case C-304/07, Directmedia Publishing GmbH v Albert-Ludwigs-Universität Freiburg (Directmedia), [2008] MMR 2008, 807.

${ }^{40}$ See for examples Recitals 7, 39 and 40 of the Database Directive.

41 See ECJ Case C-203/02, British Horseracing Board Ltd v William Hill Organization Ltd (BHB), [2004] ECR I-10415.

42 Ibid.

${ }^{43}$ ECJ Case C-338/02, Fixtures Marketing Ltd v Svenksa AB (Svenska), [2004] ECR I-10497; ECJ Case C-444/02, Fixtures Marketing Ltd v Organismos Prognostikon Agonon Podosfairou EG (OPAP), [2004] ECR I-105449; ECJ Case C-46/02, Fixtures Marketing Ltd v Oy Veikkaus Ab (Oy Veikkaus), [2004] ECR I-10365.

${ }^{44}$ Regarding the narrow interpretation of the SGDR cf. 'First evaluation of Directive 96/9/EC on the legal protection of databases', 12.12.2005, available at: http://ec.europa.eu/internal_market/ copyright/docs/databases/evaluation_report_en.pdf (last accessed 08/2013), pp. 13 et seq.
} 
In so holding the Court demonstrates adherence to a "utilitarian" reading of the function of the SGDR, as suggested by Recitals 7, 9-12, 39 and 40, clearly indicating the aim to attract more investment in the given sector through the creation of such a new right ${ }^{45}$.

It is important to underline how the Court also states that "checks ... made at the stage of creating the list ... in question ... constitute investment in the creation of data and not in the verification of the contents of the database", thereby rejecting the argument that the verification of data in the database content during the creation process could represent the required substantial investment ${ }^{46}$.

Another aspect that derives from the distinction between the creation and the obtaining of data is the problem of the so-called sole-sourced databases and the strong anti-competitive effect that such situations would cause ${ }^{47}$. In particular, as has been noted, the first draft of the Directive included a scheme of compulsory licences with the aim of avoiding such anti-competitive situations. However, it was not retained in the final version of the Directive ${ }^{48}$. The ECJ, by distinguishing between creation and obtaining, offers a solution that helps to mitigate the problem described by denying protection to databases where data is entirely created from within the enterprise that claims SGDR (a typical case of sole-source). Such a dichotomy between creation and obtaining recalls the copyright dichotomy between idea and expression, where only the latter is protected, while the former is in the public domain ${ }^{49}$. Actually, it is precisely because the former (being ideas or created data) are in the public domain that the latter (expressions and collected data) can exist and be the object of protection.

But of course, as in any case of general declamations, one thing is to find a good formula at the theoretical level, as the ECJ did with the distinction between creation and obtaining of data, whereas a completely different issue is to apply that formula to specific cases, such as that of research data, under analysis here.

45 " (9) Whereas databases are a vital tool in the development of an information market within the Community; whereas this tool will also be of use in many other fields;

(10) Whereas the exponential growth, in the Community and worldwide, in the amount of information generated and processed annually in all sectors of commerce and industry calls for investment in all the Member States in advanced information processing systems;

(11) Whereas there is at present a very great imbalance in the level of investment in the database sector both as between the Member States and between the Community and the world's largest database-producing third countries;

(12) Whereas such an investment in modern information storage and processing systems will not take place within the Community unless a stable and uniform legal protection regime is introduced for the protection of the rights of makers of databases.".

${ }^{46}$ ECJ Case C-203/02, British Horseracing Board Ltd v William Hill Organization Ltd (BHB), [2004] ECR I-10415, para. 40.

47 See M.J. Davison and P.B. Hugenholtz, 'Football fixtures, horseraces and spinoffs: the ECJ domesticates the database right', EIPR, 2005-3, pp. 113-118, p. 114.

48 Proposal for a Council Directive on the Legal Protection of Databases, COM (92)24 final, Brussels, 13 May 1992, OJ 1992 C156/4, Article 8.

${ }^{49}$ See Davison and Hugenholtz, note 47 above, p. 115. 
In fact, although we have seen that costs incurred for creating data are not considered as part of the substantial investment in making a database, the costs necessary for the verification of the accuracy of the data (with the exception of the observations above) and for the presentation of such data to third parties do count in the assessment of whether the investment was substantial ${ }^{50}$. The results of a practical application of the ECJ principles are particularly complex regarding the distinction between obtaining and creating data and regarding the concrete determination of the investment necessary to trigger the protection. This remains an evaluation that must be made on a case-by-case basis. This is particularly evident when dealing with scientific data, such as meteorological data or genetic sequences, which are not easily ascribable to one of these two categories ${ }^{51}$. Applying the criteria developed by the ECJ to scientific databases, it is unclear whether the majority of research databases meet the formal requirements for the sui generis right. Many collections of data may arguably remain outside the scope of protection because the materials constituting the database are merely created - and not obtained from already existing sources - and the threshold of substantial investment is not reached by further investing either in the verification or the presentation of such contents. However, the implicit unpredictability of this condition, which leads to a considerable amount of uncertainty regarding the overall protectability of research data and databases by the SGDR, suggests deepening further our analysis of the requirements for protection and the connected thresholds regarding infringement, as this would prove extremely helpful when facing practical cases.

\subsubsection{Substantiality: investment and infringement}

As we have seen, following the Directive's wording and the interpretation that the ECJ has consistently offered, an investment needs to be made in the obtaining, verification and presentation of the data, but not in the creation. Such interpretation is to be construed strictly since also those investments made in the verification of the data during the creation phase of the data do not qualify for protection.

Additionally, another requirement is necessary for protection as not every investment that has the aforementioned characteristics is acceptable: it needs to be substantial. Substantiality is a central concept for the SGDR as it is not only the parameter for protection, but it is also the threshold for infringement. However, unsurprisingly, no indication is given in the Directive as to the specific characteristics or amount required of an investment or an infringement in order to be considered substantial. The Directive states that substantiality can be evaluated quantitatively or qualitatively in order to qualify the investment as deserving protection.

\footnotetext{
${ }^{50}$ See A. Beunen, Protection for databases - The European Database Directive and its effects in the

Netherlands, France and the United Kingdom, Nijmegen, Wolf Legal Publishers, 2007, p. 137.

51 See Davison and Hugenholtz, note 47 above, p. 115.
} 
This is a particularly important aspect (or flaw) of the Directive since such substantiality not only determines the existence of an SGDR but also the renewal of it. In fact, any substantial change that implies a substantial investment "shall qualify the database resulting from that investment for its own term of protection" 52 . Thanks to the ECJ, we know, however, that a substantial investment does not correspond to the economic value of the database. The reward scheme and incentive-function work if they are parameterised to what has been invested, not to the final result ${ }^{53}$. However, at least at the EU level, little more guidance than that described is offered to evaluate the substantiality of the investment. There definitively needs to be more than a negligible amount of time, resources or financial assets to qualify as substantial. But they do not need to be particularly relevant or essential, at least at the EU level. We will see below what specifications Member States add in this regard.

Article 7 offers protection against acts of extraction or re-utilisation of the whole or a substantial part of the database, evaluated qualitatively or quantitatively. The same article, in its 5th section, clarifies that the repeated and systematic extraction and/or re-utilisation of insubstantial parts of the contents of the database, implying acts which conflict with a normal exploitation of that database or which unreasonably prejudice the legitimate interests of the maker of the database, shall not be permitted. Extraction of insubstantial parts of the database does not infringe the SGDR. The sense of this norm is to avoid repeated extraction of insubstantial parts, which leads to the reconstitution of the database as a whole or as a substantial part thereof. The partial re-proposition of the three-step test has to be interpreted in the sense that only if such insubstantial extractions once leading to a substantial reproduction also conflict with the normal exploitation of the database is there an infringement ${ }^{54}$. In the BHB decision the ECJ had the opportunity to clarify that there is no infringement of Article 7(5) in a case of daily takings from the $\mathrm{BHB}$ database of data relative to that single day, as there is no possibility that, through the cumulative effect of these acts, it will be possible to reconstitute and make available to the public the whole or a substantial part of the contents of the $\mathrm{BHB}$ database and thereby seriously prejudice the investment made by the $\mathrm{BHB}$ in the creation of the database $\mathrm{e}^{55}$.

\footnotetext{
${ }^{52}$ See Article 10(3): “Any substantial change, evaluated qualitatively or quantitatively, to the contents of a database, including any substantial change resulting from the accumulation of successive additions, deletions or alterations, which would result in the database being considered to be a substantial new investment, evaluated qualitatively or quantitatively, shall qualify the database resulting from that investment for its own term of protection.".

${ }^{53}$ See Davidson and Hugenholtz, note 47 above, p. 115; ECJ Case C-203/02, British Horseracing Board Ltd v William Hill Organization Ltd (BHB), [2004] ECR I-10415; Beunen, note 50 above, p. 139.

54 See ECJ Case C-203/02, British Horseracing Board Ltdv William Hill Organization Ltd (BHB), [2004] ECR I-10415; P.B. Hugenholtz, Concise European Copyright, Alphen aan den Rijn, Kluwer Law International, 2006, p. 331.

55 Ibid. (BHB), paras 83-95.
} 
Substantiality is a parameter that has to be measured against the original database on which the act of extraction has been performed, and not towards a newly created database or any other act based on the extracted part. In the case of a small database a quantitatively substantial part can be quite small in absolute terms, and definitively very small - insubstantial one could say - if compared to a much bigger, new database ${ }^{56}$. However, such considerations play no role in assessing infringement, because it results from the act of extraction and/or reutilisation (of a substantial part) of the original database. As long as there is a protected database, any extraction of a substantial part measured against it will constitute an infringement of the original database, regardless of how much bigger the new database will $\mathrm{be}^{57}$. Also, the commerciality of the extraction plays no role in the determination of the infringement ${ }^{58}$. There must be a correlation, however, between the substantiality of the investment and that of the extraction: only as long as the part extracted represents a substantial part of the investment, can there be an infringement: “... the assessment ... of whether the part at issue is substantial must ... refer to the investment in the creation of the database and the prejudice caused to that investment by the act of extracting or re-utilising that part" 59 . This holds true both for quantitative and for qualitative parts - with the former focusing on the volume of the data extracted and the latter on the scale of the investment in the extracted data ${ }^{60}$.

Accordingly, in the case of databases composed of research data, in order to determine whether a given act of extraction is substantial and therefore infringing, the comparison of the extracted (copied) amount of data has to be made against the original database. A completely different consideration is proof of the infringement, and how hard it could be to obtain it in cases where the extracted data is reassembled in a way that makes it hard to identify it, especially coming from a given protected database (since protected databases need to focus on the obtaining of the data, in many instances such data will already exist in other unprotected repositories, except of course in the case where protection is triggered by the investment in the verification and presentation). However, such latter consideration on the obtaining of proof is a matter of factual analysis, which has to be decided at trial.

More recently the ECJ had the opportunity to revisit the concept of infringement and clarified that it is occasioned by any type of extraction of a substantial part of a protected database, while the realisation of a physical copy of the data is

\footnotetext{
56 See ibid, para. 70.

57 See Beunen, note 50 above, p. 186; ECJ Case C-203/02, British Horseracing Board Ltd v William Hill Organization Ltd (BHB), [2004] ECR I-10415, para. 47.

58 See ibid. (BHB), para. 48.

59 Ibid., para. 69.

${ }^{60}$ Ibid., paras 70 and 71.
} 
not necessary ${ }^{61}$. The Directmedia case is particularly relevant in this instance as it relates to the reuse by a private company of a database (or rather a substantial part thereof) created within the academic environment. Even more interesting, the decision of the ECJ is based on the uncontested assumption that a private company (Directmedia) had access to the database, and consulted it (an act indisputably permitted by the Directive) ${ }^{62}$. Further, and here lies the problematic aspect, Directmedia created a new database that incorporated substantial parts of the original, albeit not a physical or mechanical copy of it. With such a referral the German Federal Court of Justice $\left(\mathrm{BGH}^{63}\right)$ aims to ascertain whether the concept of extraction "covers the operation of transferring the elements of one database to another database following visual consultation of the first database and a selection on the basis of a personal assessment of the person carrying out the operation or whether it requires that a series of elements be subject to a process of physical copying"64.

The ECJ sustains the interpretation that no physical copy is necessary to originate infringement, and that the transfer of elements from one database by visual consultation and selection on the basis of personal assessment plays no role in the determination of the infringement. This aspect is particularly relevant for the subject of our analysis. In many scientific and academic environments it might seem natural that the mere consultation of a series of data should not cause any harm to any legally protected situation. This is actually a correct assumption and for the case of the SGDR the ECJ stated that "the protection of the sui generis right concerns only acts of extraction and re-utilisation [which do not] cover consultation of a database" 65 . The issue under consideration in the present case, however, lies exactly in between mere consultation and extraction ${ }^{66}$ : once a party has (legally) consulted a database, what is he allowed to do with the information he carries away with him as the result of the act of consultation? In the opinion of the ECJ no act will lead to the reconstitution of the database or a substantial part thereof, including in an adapted or modified form:

It is also immaterial ... that the transfer of the contents of a protected database may lead to an arrangement of the elements concerned which is different from that in the original database. ... an unauthorised act of copying, accompanied by an adaptation of the con-

\footnotetext{
${ }^{61}$ See ECJ Case C-304/07, Directmedia Publishing GmbH v Albert-Ludwigs-Universität Freiburg (Directmedia), [2008] MMR 2008, 807; See also the AG opinion delivered on 10 July 2008.

62 See ECJ Case C-203/02, British Horseracing Board Ltd v William Hill Organization Ltd (BHB), [2004] ECR I-10415, para. 54.

${ }^{63}$ German: Bundesgerichtshof (BGH).

${ }^{64}$ See ECJ Case C-304/07, Directmedia Publisbing GmbH v Albert-Ludwigs-Universität Freiburg (Directmedia), [2008] MMR 2008, 807, para. 22.

${ }^{65}$ See ECJ Case C-203/02, British Horseracing Board Ltd v William Hill Organization Ltd (BHB), [2004] ECR I-10415, para. 54.

${ }^{66}$ Ibid., AG Opinion, para. 29.
} 
tents of the database copied, is among the acts against which that directive seeks, through the establishment of the sui generis right, to protect the maker of such a database ${ }^{67}$.

In light of the present analysis we can safely affirm that the Directive together with constant case law construes the concept of "extraction" in a broad manner, so as to include any medium and form, regardless of the nature and purpose of such extraction ${ }^{68}$. The key concept in order to determine whether an infringing extraction has occurred is the "transfer" of data, which needs to be of the whole or a substantial part of the original database, but need not be a physical or mechanical act of copying. Such transfer, the Court adds, does not need to be permanent either, for a temporary transfer also infringes the SGDR ${ }^{69}$. Of course, the mere fact that the same elements are present in the original database as well as in the allegedly copied one is not sufficient in itself to prove infringement. The protection offered by the SGDR, similar to that offered by copyright, is against acts of copying (rectius: extraction), therefore an independent database consisting of similar or even the same elements (a whole or a substantial part) can be not infringing if it represents an independent product. The fact that the SGDR does not protect created data implies that an SGDR-protected database has to have obtained the data from somewhere else, therefore the same obtaining can have been independently carried out by a second non-infringing database maker from a different, or even from the same, original, unprotected, source. As the ECJ had the opportunity to enunciate: The fact ... that the physical and technical characteristics present in the contents of a database also appear in the contents of another database may also be interpreted as an indication of the existence of a transfer between the two databases and therefore, of an extraction. However ... it is [for the national court] to assess whether that coincidence can be explained by other factors, such as the use of identical sources when the two databases were being set up and the presence of those characteristics in the common sources ${ }^{70}$.

\footnotetext{
${ }^{67}$ See ECJ Case C-304/07, Directmedia Publisbing GmbH v Albert-Ludwigs-Universität Freiburg (Directmedia), [2008] MMR 2008, 807, para. 39.

${ }^{68}$ See ECJ Case C-545/07, Apis-Hristovich v Lakorda (Apis), [2009] GRUR Int. 2009, 501.

${ }^{69}$ See ibid., para. 42; The Court clarifies though that the permanent of temporary nature of the transfer may reflect on the levels of awarded damages if in accordance with Member State legislation.

70 See ibid., para. 51; also relevant, para. 52: "It should also be stated, as the Bulgarian Government does, that the fact that materials obtained by the maker of a database from sources not available to the public also appear in a database made by another person is not, as such, sufficient to prove that there has been a transfer from the first database to the second, having regard to the possibility that those materials might also have been collected directly by the maker of the second base from the sources used by the first maker. That fact may, none the less, constitute circumstantial evidence of extraction.".
} 


\subsubsection{Scope of protection}

Where the "obtaining, verification or presentation" of research datasets does manifest the substantial investment necessary to qualify for protection, the sui generis protection confers two transferable rights on the maker of a database: the right of extraction and the right of re-utilisation of substantial parts of the database. The Directive defines them as follows:

"Extraction shall mean the permanent or temporary transfer of all or a substantial part of the contents of a database to another medium by any means or in any form; while reutilisation shall mean any form of making available to the public all or a substantial part of the contents of a database by the distribution of copies, by renting, by online or other forms of transmission."

These two concepts have received a broad interpretation from the ECJ ${ }^{71}$. In the Directmedia case, as seen above, the Court found that an act of "extraction" occurs when all or part of the contents of the database concerned are transferred to another medium, whether of the same or of a different nature. Such a transfer implies that all or a substantial part of the contents of a database can be found in a medium other than the original database ${ }^{72}$. In the view of the ECJ, it is irrelevant whether the transfer is based on a technical process of copying the contents of a protected database or on a simple manual process; similarly, it is irrelevant that the transfer of the contents of the database may lead to an arrangement of the elements that is different from the one in the original. The Court adds that the transfer of material from a protected database to another database following an onscreen consultation of the first database and an individual assessment of the material contained in that first database is also capable of constituting an extraction.

In the BHB decision, the Court ruled that the concept of "re-utilisation" must be understood broadly, as extending to any act, not authorised by the maker of the database protected by the sui generis right, of distribution to the public of the whole or a part of the contents of the database. The Court observed that the nature and form of the process are of no relevance in this respect ${ }^{73}$.

The protection under the sui generis right lasts for 15 years from 1 January of the year following the date on which the database was completed. The term of protection for a database may start anew under two conditions, both dealing with the term "substantial". The first one is represented by a substantial modification of the contents of the database, evaluated either qualitatively or quantitatively, which can consist in additions, deletions or alterations (including rearrangement of

\footnotetext{
${ }^{71}$ ECJ ECJ Case C-304/07, Directmedia Publishing GmbH v Albert-Ludwigs-Universität Freiburg (Directmedia), [2008] MMR 2008, 807; ECJ Case C-545/07, Apis-Hristovich v Lakorda (Apis), [2009] GRUR Int. 2009, 501.

72 Ibid. (Directmedia), para. 36.

${ }^{73}$ ECJ Case C-203/02, British Horseracing Board Ltd v William Hill Organization Ltd (BHB), [2004] ECR I-10415, para. 61.
} 
the contents). Secondly, this substantial modification must represent a substantial investment, evaluated qualitatively or quantitatively. This is one of the most controversial and criticised provisions of the Directive since it apparently offers grounds for a perpetual protection of the databases ${ }^{74}$.

Finally, it is worth pointing out that, according to Article 11 of the Database Directive, only natural persons who are nationals of a Member State or who have their habitual residence in the territory of the EU can benefit from the database right. Furthermore, companies and firms are also entitled to such protection if they are formed according to the law of a Member State and have their registered office, central administration or principal place of business within the EU. Article 11(2) clarifies that where a company or a firm has a registered office only in the territory of the EU, its operations must be substantially and durably linked with the economy of a Member State. In other words, the protection of the SGDR is not only unique to Europe in that it is conferred only on EU nationals, whether natural or legal persons, but also because no other major competing partner of the EU has set up a comparable regime of protection for non-original databases.

The complexity of the rights status of research data arguably has the potential to adversely affect the reuse opportunities of collections of scientific data, given the difficulty - both for research institutions making the database available and for prospective reusers - in determining each time whether a certain database is covered by the sui generis right and to what extent re-utilisation and extraction can take place freely.

\subsubsection{The beneficiary of the protection}

Should research datasets indeed show a level of substantial investment in the "obtaining, verification or presentation" of the data to qualify for protection, the second question to be addressed is who qualifies as the maker of the database. More specifically, does a research institution, or the individual researcher, benefit from the protection even if the investment is made possible only through the injection of public funding?

Recalling the wording of Recital 41 of the Directive, the maker of the database is the person who takes the initiative and the risk of investing. Whether the research institution or the individual researcher is to be considered as the "maker of the database" may be a question of fact. It may depend on such factors as the financing structure of the university, the department or the research project, the conditions of the grant or subsidy and the legal relationship between the researcher and his institution. It may also depend on how Recital 41 of the Directive has been implemented in national legislation, if at all, and whether it puts the accent on the initiative taker, the risk of investing or on another element.

\footnotetext{
${ }^{74}$ J.H. Reichman, 'When Copyright Law and Science Collide: Empowering Digitally Integrated
} Research Methods on a Global Scale' (2012) 96 Minn. L. Rev. 1362, 1451. 
We will see below that some national implementations present a specific and interesting position in this regard, although probably unique within the EU. At the EU level, the ECJ recently rendered a decision in the Compass-Datenbank case ${ }^{75}$ in which it indirectly confirmed that public entities are entitled to own and exercise sui generis database rights. The referring Austrian court asked, in essence, whether the activity of a public authority in permitting interested persons to search for data and in providing them with printouts thereof in return for payment, while prohibiting any other use of that data by relying on its sui generis database right, constitutes an economic activity of an undertaking within the meaning of Article 102 TFEU $^{76}$. The Court answered in the negative. Incidentally, the Court declared that:

a public entity which creates a database and which then relies on intellectual property rights, and in particular the abovementioned sui generis right, with the aim of protecting the data stored therein, does not act, by reason of that fact alone, as an undertaking. Such an entity is not obliged to authorise free use of the data which it collects and make available to the public ${ }^{77}$.

From this ruling it seems that the Court does not see any grounds for preventing public bodies from qualifying as makers of a database due to the mere fact that the substantial investment is made through public funding. The ECJ exercised judicial restraint in the Compass-Datenbank case and refrained from examining the level of investment that might have given rise to protection. So the case does not tell whether the investment made by the Austrian government demonstrated the required "substantial investment" to qualify for protection. However, provided "substantial investment" is directed to obtaining, verifying and presenting the data, the fact that scientific databases are produced with public funding should not deprive research institutions or researchers, depending on who bears the risk of investment, from benefiting from the sui generis protection under the European Directive (with the exception of the Netherlands, see below Chapter 2.4.3.2.2).

\subsubsection{Exceptions and limitations to restricted acts}

Regarding exceptions and limitations to the restricted acts set forth by the Database Directive - as for many other elements here analysed - two different approaches, one for copyright and the other for the SGDR, need to be developed.

Regarding copyright, it is Article 6(1) Database Directive that determines that "the performance by the lawful user of a database of any of the acts listed in Article 5 which is necessary for the purposes of access to the contents of the databases and normal use of the contents shall not require the authorisation of the author of the database". Article 6(1) outlines the only mandatory exception re-

\footnotetext{
75 ECJ Case C-138/11, Compass-Datenbank GmbH v Republik Österreich, [2012] EuZW 2012, 835.

${ }^{76}$ Treaty on the Functioning of the European Union.

77 ECJ Case C-138/11, Compass-Datenbank GmbH v Republik. Österreich, [2012] EuZW 2012, 835, para. 47.
} 
garding the copyright in databases listed by the Directive. The following section (2) of the same article lists three cases where Member States have the option of providing for limitations to restricted acts: (a) reproduction for private purposes of a non-electronic database; (b) use for the sole purpose of illustration for teaching or scientific research, as long as the source is indicated and to the extent justified by the non-commercial purpose to be achieved; (c) use for the purposes of public security or for the purposes of an administrative or judicial procedure.

Section 2 closes with a general provision (letter d) allowing other exceptions to copyright which are traditionally authorised under national law, without prejudice to points (a), (b) and (c). The article's last section (3) introduces two steps of the three-step test (unreasonable prejudice to rightholder's legitimate interests and conflict with normal exploitation of the database). Article 6(3)'s explicit reference to Article 9(2) Berne Convention is somewhat misleading, since the three-step test as contained in the latter only applies to exceptions to the reproduction right, whereas the exceptions to which Article 6 refers apply to all economic rights granted by Article $5^{78}$.

It must be recalled here that the compulsory exception of Article 6(1) applies to all acts covered by Article 5 (i.e. temporary or permanent reproductions, translations, adaptation, arrangement and any other alteration, distribution, communication, display or performance to the public of the original or of any modified, adapted or translated parts). Therefore, those national implementations that only list some of the acts regarded are in contrast to EU law. Further, Article 6(1) only applies in the case of a lawful user, unlike the cases contained in Article 6(2). The concept of "lawful user" will be clarified below.

Regarding the limitations to the SGDR, we have to turn our attention to Article 9, which offers three cases where Member States can stipulate that a lawful user of a database does not need any authorisation in cases of: (a) extraction for private purposes of the contents of a non-electronic database; (b) extraction for the purposes of illustration for teaching or scientific research, as long as the source is indicated and to the extent justified by the non-commercial purpose to be achieved; and (c) extraction and/or re-utilisation for the purposes of public security or an administrative or judicial procedure. Article 9 lists a rather limited number of exceptions to the SGDR, especially if we consider that only the third case - a special case by itself - allows re-utilisation, while the first two only exempt acts of extraction (although once more the drafting technique and the use of the English language is quite lax $)^{79}$. Such limited scope clashes with the rather

\footnotetext{
${ }^{78}$ See Hugenholtz, note 54 above, p. 326.

${ }^{79}$ In the first sentence the reference is to both extraction and re-utilisation ".... users of a database ... may ... extract or re-utilise a substantial part of its contents", but in the following first two cases it is only made reference to acts of extraction "in the case of extraction for private purposes". Under a purely literal analysis it should be inferred that in cases of extraction for private purposes or for illustration for teaching or research, acts of extraction or re-utilisation are allowed: a
} 
large scope of Article 6 exemptions to copyright in databases (especially in terms of activities exempted, all those of Article 5), as well as to the traditional exceptions to copyright contained, for example, in Article 5 Info Directive (a formal reading lists 21 different cases).

A key concept of EU database legal provisions that encompasses both Articles 6 and 9 is that of a lawful user. In fact, only a lawful user is exempted from Article 5 exclusivity for the cases of access and normal use of a database as provided in Article 6(1). Notably, the exemptions listed in Article 6(2) are not limited to lawful users but extend to anybody (therefore also to unlawful users, whatever this means). Contrarily, only a lawful user will benefit from the exceptions to the SGDR listed in Article 9. In spite of the importance and centrality attributed to it by the Directive, the concept of a lawful user finds no definition in the Directive, nor is it known in the aquis of international agreements in the field of copyright or other intellectual property rights. Similar, though not identical, concepts can be found in other EU directives, such as the Computer Programs Directive ("lawful acquirer"), and the Info Directive ("lawful use"). Recital 34 Database Directive offers some guidance:

"Whereas, nevertheless, once the rightholder has chosen to make available a copy of the database to a user, whether by an online service or by other means of distribution, that lawful user must be able to access and use the database for the purposes and in the way set out in the agreement with the rightholder, even if such access and use necessitate performance of otherwise restricted acts."

A literal interpretation suggests that once the rightholder makes the database available to a user, this becomes a lawful user. In consequence, an unlawful user would be a user that has access to a database against the intentions of the rightholder. Such access, however, needs to follow the purposes and ways set out in the agreement with the rightholder. In such a case agreement needs to be interpreted in a broader manner, not reduced to the narrow interpretation of contractual agreement, which would lead to absurd results. In particular, a person or entity invoking a copyright or SGDR exception is a lawful user and can therefore benefit from Articles 6(1) and $9^{80}$. Lawful users are also persons or entities that use the database as it is freely available online (websites in many instances), also in the absence of any specific terms of use, on the basis of an implied authorisation, as long as it has been published by (or with the consent of) the rightholder. Even more, purchasers of copies (digital or analogue) of the database are lawful users. However, a person obtaining an illegal copy of a database will probably not be considered a lawful user and therefore will not be able to enjoy the exceptions

complete nonsense. It could also be questioned what is the real value of an obligation to indicate the source, if no act of re-utilisation can be performed.

80 See Hugenholtz, note 54 above, p. 324. 
listed in Articles 6(1) and 9. Such person, however, will be allowed to invoke the exceptions of Article 6(2).

Recital 52 Database Directive entitles those countries that already have a form of protection similar to the SGDR (such as the Nordic countries or the Netherlands) to retain the exceptions (usually the same as those listed by such countries for copyright purposes) also for the case of the SGDR. In these countries it would be possible to find more SGDR exceptions than those listed by the Directive.

An important provision with regard to the exceptions and limitations to both copyright and the SGDR with regard to database protection is that set forth by Article 15 entitled "Binding nature of certain provisions", which states that any contractual provision contrary to Articles 6(1) and 8 shall be null and void.

\subsubsection{SGDR and OpenAIREplus}

Within the project of OpenAIREplus, a complex database of records of publications and research data is created. Unlike most of the European research projects, the aim of the project is not to gain new knowledge through basic research in the area of hard or social sciences. The OpenAIREplus project directly aims at the creation of a complex database as a research infrastructure for all information related to scientific publications resulting from EU-funded research, complemented by research data and research information. Thus OpenAIREplus is not just a tool to query other databases, but a complete database which collects data, especially metadata, about every kind of scientific publication.

The main objective of the whole project is the creation of this database. The elements of the database will be systematically and methodically arranged and individually accessible electronically over the internet. For its creation, a great amount of technical, human and financial effort is required. Therefore, the technical requirements and the requirement of a qualitatively and/or quantitatively substantial investment in the obtaining, verification or presentation of the contents, for obtaining sui generis protection, are clearly met.

But if the criteria for sui generis protection are met, the next important question arises: Who is the owner of such IP right? The rightholder is generally the maker of the database. According to Recital 41 of the Database Directive, the maker of the database is the person who takes the initiative and the risk of investing. In an employment relationship, the owner of the sui generis right usually will not be the natural person who creates the database, but his employer, who pays for the creation of the database and thereby carries the financial risk of the database creation. In the case of OpenAIREplus, the employers of the different researchers who create the OpenAIREplus database are different legal entities, mainly universities and research institutes. At first sight this would mean that these entities become the owners of the OpenAIREplus database right. However, it is questionable whether these entities are really the ones who take the initiative and the risk of investing. To be precise, it is not the research entities that carry the main financial 
risk, but the funder of the project, in this case the European Commission. Without the European Commission's massive funding, the database would not be created.

Nevertheless, the research entities take the initiative for the creation of the database too, due to the fact that they hand in the proposal for a project to be funded by the European Commission. Furthermore, they also bear a financial risk in investing in the database, since an EU project is generally not funded on a fullcost basis, which means that the research entities do have to raise some money by themselves.

As a result, there are plenty of indications that the European Commission as well as the project partners who contribute in a sufficient amount to the creation of the OpenAIREplus database are generally becoming co-owners of the sui generis right in this database. But neither this question nor the question as to which coownership rules should govern the relationship between the different entities have yet received sufficient answers ${ }^{81}$.

\subsection{National implementations}

In the following section, we will evaluate how different Member States have implemented the EU directives and what differences still exist.

\subsubsection{United Kingdom}

\subsubsection{Protection as a copyright work}

One very effective method for protecting research data seems to be copyright law. The UK copyright law is regulated by the Copyright, Design and Patents Act 1988 (CDPA 1988). According to section 1(1) CDPA 1988, copyright is a kind of property right.

\subsection{The copyright work}

The central element of copyright protection is the copyright work. Therefore, it is remarkable that no legal definition of this term is given in the CDPA 1988. Section 1(2) CDPA 1988 just states that: "In this Part 'copyright work' means a work of any of those descriptions in which copyright subsists." This section thereby refers to section 1(1) CDPA 1988 in which different kinds of work are named. Thus it makes sense to have a closer look at the different work categories referred to, before examining the other requirements for copyright protection.

\footnotetext{
${ }^{81}$ See below Chapter 2.5.1.
} 


\subsection{Kinds of work}

Copyright law is designed to protect aesthetic and artistic creations known as original works, together with derivative works ${ }^{82}$. Today, there is no formal distinction between the different categories of work; nonetheless an informal distinction can be drawn between the two general categories of subject matter.

Original works are created by authors (therefore sometimes also called authorial works). These works are named in section 1(1)(a) CDPA 1988: literary works, dramatic works, musical works and artistic works. Derivative works, on the other hand, are neighbouring rights, which refer to works created by entrepreneurs (therefore sometimes also called entrepreneurial works). These works are named in section 1(1)(b) and (c) CDPA 1988: sound recordings, films, broadcasts and typographical arrangements of published editions.

\subsection{Criteria for copyright protection}

The two different kinds of work have different requirements for protection. Authorial works have to be original. This requirement is explicitly mentioned in section 1(1)(a) CDPA 1988.

Originality does not mean that the work has to be inventive, novel or unique. Peterson J expressed the idea of originality in the case of University of London Press $v$ University Tutorial Press ${ }^{83}$ :

"The word original does not in this connection mean that the work must be the expression of original or inventive thought. The originality which is required relates to the expression of the thought. But the Act does not require that the expression must be in an original or novel form, but that the work. must not be copied from another author workthat it should originate from the author."

This broad vision of originality is necessary, because it is not possible to determine objectively whether a work is inventive or unique; this depends on people's taste.

The second requirement for originality is that the work in question requires a minimum of labour, skill and effort. Behind this lies the idea that simple copying does not involve the requisite degree of activity to justify the award of copyright ${ }^{84}$.

The leading case on originality is Walter $v$ Lane $^{85}$. In this case, the House of Lords decided that copyright subsists in a reporter's transcription of a speech by Lord Rosebery, a leading politician of the day, because his creation was not a mere transcription of the speech, but had involved the expenditure of individual skill and effort.

\footnotetext{
${ }^{82}$ H. MacQueen, C. Waelde, G. Laurie and A. Brown, Contemporary Intellectual Property: Law and Policy, 2nd edition, Oxford, Oxford University Press, 2010, para. 1.7.

83 University of London Press v University Tutorial Press, [1916] 2 Ch 601, para. 608.

${ }^{84}$ MacQueen, Waelde, Laurie and Brown, note 82 above, para. 2.39.

85 Walter $v$ Lane, [1900] AC 539.
} 
This common law concept of copyright deviates considerably from continental copyright, which bases protection on originality in the sense that the work is the expression of the individual personality of the author. Hence, mere original creation would not be enough but some level of individual contribution has to be demonstrated. In effect, this is a higher standard.

The requirement of originality does not apply to derivative works; but copyright does not subsist in a derivative work which is, or to the extent that it is, a copy taken from a previous work in the same category ${ }^{86}$. The reason for this lower standard for entrepreneurial works is that these are derivatives of existing authorial works in the sense that they use or develop these works. Therefore it is simply not possible to fulfil the requirement of originality.

Copyright protection requires the work to have some tangible form. This seems obvious for derivative works such as sound recordings, artistic works and films because their existence implies tangibility. Authorial works such as literary, dramatic or musical works, on the other hand, can exist without any tangible form. Section 3(2) CDPA 1988 states that copyright does not subsist in such a work unless and until it is recorded, in writing or otherwise. This requirement means that there is no copyright, for instance, in the unrecorded spoken word; however, as soon as a recording is made (even by another person), the words have copyright and the subsequent reproduction and publication of these words may be controlled by the speaker ${ }^{87}$.

Regarding the copyright protection of research data, one must note that there is no common definition of what research data is in the context of intellectual property law ${ }^{88}$. Taking a broad approach, research data can be every kind of data produced in the course of scientific research, and thus no general statement can be given about the copyright protection of this data. Copyright protection depends on whether the data in question fulfils the criterion of originality or not. Copyright protection is especially relevant for the creation of scientific papers, but raw research data will normally not be protected by copyright ${ }^{89}$.

\subsection{Authorship and ownership}

Authorship and ownership are, in relation to copyright, two distinct concepts, each of which attracts its own peculiar rights: the author having moral rights and the owner of the copyright possessing economic rights ${ }^{90}$. One can say that there is

\footnotetext{
86 Cf. sections 5A(2), 5B(4), 8(2) CDPA 1988.

87 Cf. MacQueen, Waelde, Laurie and Brown, note 82 above, para. 2.32.

88 Likewise: The study of Knowledge Exchange, Annex 4 - The legal status of research data in the United Kingdom, available at: http://www.knowledge-exchange.info/Default.aspx?ID=461 (last accessed 06/2013), p. 10.

89 Ibid.

${ }^{90}$ Cf. D.I. Bainbridge, Intellectual Property, 8th edition, Harlow, Longman, 2010, p. 85.
} 
not only one right, but the authorship and the copyright constitute two different rights of the same origin.

According to section 9 CDPA 1988 the author of a work is the person who creates it. The author shall be taken to be the producer in the case of sound recordings, the producer and the principal director in the case of films, the person making the broadcast in the case of broadcasts, or, in the case of a broadcast which relays another broadcast by reception and immediate re-transmission, the person making that other broadcast, and, in the case of typographical arrangements of published editions, the publisher. For example, the author of a work of literature is the person who writes it; the author of a piece of music is its composer and so on ${ }^{91}$.

Copyright protection arises automatically with the creation of the work. According to section 11(1) CDPA 1988, the first owner of the copyright in the work is typically the author. However, where a work of authorship is made by an employee in the course of his employment, his employer is the first owner of any copyright in the work subject to any agreement to the contrary (section 11(2) CDPA 1988).

Copyright is a property right, and as such the owner of that right can deal with it $^{92}$. Therefore, copyright is generally alienable and may be transferred or assigned, in whole or in part, and the owner of copyright may license one or more specific uses of his work ${ }^{93}$. However, it should be noted that even if the author is not the owner of the copyright, he still has his moral rights, which have to be respected ${ }^{94}$.

Section 10(1) CDPA 1988 defines a "work of joint authorship" as a work produced by the collaboration of two or more authors in which the contribution of each author is not distinct from that of the other author or authors. These coauthors share the rights related to the work (cf. section 10(4) CDPA 1988).

\subsection{Exclusive rights}

The copyright owner (not the author) has some exclusive rights. These are mentioned in section 16(1) CDPA 1988: the right to copy the work, to issue copies of the work to the public, to rent or lend the work to the public, to perform, show or play the work in public, to communicate the work to the public or to make an adaptation of the work or do any of the other acts in relation to an adaptation.

A licence must be sought if these restricted acts are to be lawfully carried out by a person other than the copyright owner ${ }^{95}$. In other words: a copyright in-

\footnotetext{
91 Ibid., pp. 86 et seq.

92 Ibid., p. 103.

${ }^{93}$ K. Garnett, G. Davies and G. Harbottle (eds), Copinger and Skone James on Copyright, 16th edition, London, Sweet \& Maxwell, 2010, vol. I, 2-03.

${ }^{94}$ This is usually not a problem in the context of economic exploitation. The two principal moral rights are the paternity right (section 77 CDPA 1988) and the integrity right (section 80 CDPA 1988).

95 Cf. MacQueen, Waelde, Laurie and Brown, note 82 above, para. 4.10.
} 
fringement is committed if one of the above-mentioned restricted acts is carried out without the permission of the rightholder.

\subsection{The right to copy the work (section 17 CDPA 1988)}

According to section 17 CDPA 1988, the copying of the work is an act restricted by the copyright in every description of copyright work. The meaning of copying varies depending on the nature of the work (cf. section 17(2)-(5) CDPA 1988). Copying includes the making of transient or temporary copies (section 17(6) CDPA 1988). In relation to the important work category of authorial works, copying means reproducing the work in any material form including storing the work in any medium by electronic means.

Thus copying is the permanent or temporary reproduction of a work in any material, analogue or electronic form.

\subsection{The issuing of copies of the work (section 18 CDPA 1988)}

Issuing copies of the work to the public means putting into circulation copies not previously put into circulation in the European Economic Area (EEA) by or with the consent of the copyright owner, or putting into circulation outside the EEA copies not previously put into circulation in the EEA or elsewhere.

The owner of the copyright has the right to be first to produce copies of the work to be available to the public. The right is therefore sometimes described as the right of first sale or of distribution. Only the copyright owner or his licensee can put a new reproduction of the work on the market ${ }^{96}$.

A limitation to this right is its "exhaustion". The right is not applicable to any subsequent distribution, sale, hiring or loan (cf. section 18(3) CDPA 1988). Once the copyright owner has put copies of the work on the market, he should not be able to restrict further dealing with those copies. This is because he was able to get remuneration for the first act of distribution and should not be able to further restrict the free movement of goods.

\subsection{The rental and lending right (section 18A CDPA 1988)}

Section 18A CDPA 1988 contains a specific provision for rental and lending. In general, rental and lending is a restricted act, even if the work was put into circulation. The right applies to original works, films and sound recordings. However, there is an exception with regard to artistic works; the right does not apply to artistic works of architecture in the form of a building and works of applied art.

${ }^{96}$ Ibid., para. 4.43 . 


\subsection{The public performance right (section 19 CDPA 1988)}

According to section 19(1) CDPA 1988 the performance of the work in public is an act restricted by copyright in a literary, dramatic or musical work. In the context of research data, this right is of minor importance.

\subsection{The public communication right (section 20 CDPA 1988)}

The communication to the public of the work is an act restricted by the copyright in literary, dramatic, musical and artistic works, sound recordings, films and broadcasts (section 20(1) CDPA 1988).

This exclusive right covers broadcasting and internet transmissions of works ${ }^{97}$. With regard to the internet, for example, placing a work on a website or facilitating its downloading from a website will infringe copyright in the work ${ }^{98}$.

\subsection{The adaptation right (section 21 CDPA 1988)}

The making of an adaptation of a literary, dramatic or musical work is a restricted act according to section 21 CDPA 1988. An adaptation is made when it is recorded in writing, or otherwise. The performance of any of the other restricted acts in relation to an adaptation is also a restricted act.

Making an adaptation does not simply mean the same as modifying a work ${ }^{99}$. Section 21(3) CDPA 1988 defines an adaptation in relation to literary or dramatic works as a translation of a work; the conversion of a dramatic work into a nondramatic work and vice versa; or a version of the work in which the story is conveyed by means of pictures in a form suitable for reproduction in a book, magazine or similar periodical. In relation to computer programs and databases, adaptation means an arrangement or altered version, or a translation.

\subsection{Limitations}

The definition of an infringement in relation to the six named restricted acts seems to be very simple. However, there are some principles and limitations to these potential acts of infringement.

\subsection{Ideas}

At first it is important to note that ideas are excluded from copyright protection under UK law. This principle means that copyright cannot subsist in the ideas that are expressed, but exclusively in the expression of the ideas. Lord Hoffmann said the following in Designers Guild v Russell Williams (Textiles) Ltd ${ }^{100}$ :

\footnotetext{
97 Cf. ibid., para. 4.61.

${ }^{98}$ Cf. Bainbridge, note 90 above, p. 170.

99 Ibid., p. 171.

100 Designers Guild v Russell Williams (Textiles) Ltd, [2001] FSR 11, paras 24 and 25.
} 
"Plainly there can be no copyright in ideas ... either because they have no connection with the literary, dramatic, musical or artistic nature of the work or because they are not original, or so commonplace as not to form a substantial part of the work.".

\subsection{Taking a whole or substantial part}

Section 16(3)(a) CDPA 1988 states that an infringement may be constituted by the doing of an act of infringement in relation to the work as a whole or any substantial part of it. It follows that if what is done is in relation to an insubstantial part of a work there is no infringement ${ }^{101}$. This principle is applicable to all of the restricted acts mentioned in the CDPA 1988. However, statute does not define what a substantial part of a work actually is. So it is up to the courts to decide whether a part is substantial or not.

In Ladbroke (Football) Ltd $v$ William Hill (Football) Ltd it is said that ${ }^{102: ~ " W h e t h e r ~}$ a part is substantial must be decided by its quality rather than its quantity. The reproduction of a part which by itself has no originality will not normally be a substantial part of the copyright and therefore will not be protected."

However, to be a substantial part the section taken does not have to be a copyright work in its own right ${ }^{103}$. Taking part of a compilation of unoriginal material may still be deemed to be a substantial part of the entire work, meaning that copying a small portion of a work can infringe copyright if that part is important in relation to the whole work ${ }^{104}$. Hence, the correct approach is first to determine whether the work as a whole is "original" and protected by copyright, and then to inquire whether the part taken by the defendant is substantial 105 . The following examples should help to clarify what a substantial part can be:

a) In Infopaq International $A / S v$ Danske Dagblades Forening 106 it was held that printing out an extract of 11 words of a copyright work could be "reproduction in part" if the elements reproduced were the expression of the intellectual creation of their author.

b) In Hawkes \& Sons (London) Ltd v Paramount Film Service Ltd ${ }^{107}$ it was held that the use of a portion of only 20 seconds of a march which lasted some four minutes can infringe copyright in the march.

\footnotetext{
101 MacQueen, Waelde, Laurie and Brown, note 82 above, para. 4.15.

102 Ladbroke (Football) Ltd v William Hill (Football) Ltd, [1964] 1 WLR 273; likewise Warwick Film Productions Ltd v Eisinger, [1969] 1 Ch 508.

103 MacQueen, Waelde, Laurie and Brown, note 82 above, para. 4.15; see also Ladbroke (Football) Ltd $v$ William Hill (Football) Ltd, [1964] 1 WLR 273.

104 Bainbridge, note 90 above, p. 146.

${ }^{105}$ Ladbroke (Football) Ltd v William Hill (Football) Ltd, [1964] 1 WLR 273.

106 Cf. ECJ Case C-5/08, Infopaq International A/S v Danske Dagblades Forening, [2009] ECDR 16.

107 Hawkes \& Sons (London) Ltd v Paramount Film Service Ltd, [1934] Ch 593.
} 
These cases demonstrate that even using a very small part of a work can be sufficient to commit an infringement.

\subsection{Authorisation of infringement/permitted acts}

According to section 16(2) CDPA 1988, the copyright in a work is only infringed by a person who does or authorises another to do any of the restricted acts without the licence of the copyright owner. That means that there cannot be an infringement if the copyright owner has authorised or consented to the act of infringement, e.g. by granting a licence to the responsible person.

Furthermore, the CDPA 1988 contains a number of acts permitted in relation to copyright works. These acts can be carried out without the owner's permission. The rationale for the permitted acts, allowing what would otherwise be an infringement of copyright, can be seen as a way of limiting the strength of the rights associated with copyright. The justification for this restriction is that it provides a fair balance between the rights of the copyright owner and the rights of society at large $\mathrm{1}^{108}$.

The acts permitted in relation to copyright are complex and wide ranging in their scope and application ${ }^{109}$, but at least some of the most important regulations will be described ${ }^{110}$.

A temporary reproduction of a work that is transient or incidental is allowed when it is necessary to enable the lawful use and has no independent economic significance (section 28A CDPA 1988).

The Act also contains some fair dealing provisions. No fair dealing with an original work will constitute an infringement if it is carried out for one of the following purposes: research for a non-commercial purpose (section 29(1) CDPA 1988); private study (section 29(1) CDPA 1988); criticism or review (section 30(1) CDPA 1988); reporting current events (section 30(2) and (3) CDPA 1988). However, which kind of dealing with a work is fair or not is not defined, and it is again up to the courts to establish in each case whether a dealing is fair or not.

With respect to original works, copyright expires at the end of the period of 70 years from the end of the year in which the author dies (section 12(2) CDPA 1988). For other types of work, the period is 50 years or 25 years.

\subsubsection{Protection as databases}

Databases are a very important tool in the area of scientific research. It is useful to store, process and utilise data, such as raw research data in a database. In the UK, there are two different ways to protect databases. First, it is possible to gain copy-

\footnotetext{
108 Bainbridge, note 90 above, p. 211.

109 Ibid.

${ }^{110}$ For a detailed overview of the permitted acts see ibid., pp. 234 et seq., Table 7.2.
} 
right protection over the database, and secondly, protection under the sui generis database right is possible as well.

\subsection{Copyright protection}

A database which meets the requirements for copyright protection may be protected by copyright. The regulations for ownership and the restrictive acts are generally the same as for other work categories; a special definition is just used for the adaptation right. In relation to databases, adaptation means an arrangement or altered version of the database, or a translation of $i^{111}$.

\subsection{Compilations and databases}

According to section 3(1)(a) CDPA 1988, compilations are protectable as a literary work. Databases can always be seen as compilations ${ }^{112}$ and were thought to be protected under UK law as such ${ }^{113}$. However, since the implementation of the Database Directive ${ }^{114}$, databases are explicitly excluded from the term "compilation"; section 3(1)(a) CDPA 1988 states that a literary work is a table or compilation other than a database.

Databases are now protected as a separate type of literary work. Section 3A CDPA 1988 contains a specific definition of databases: Databases are "collections of independent works, data or other materials arranged in a systematic or methodical way and individually accessible by electronic or other means".

\subsection{Originality}

Databases have their own definition of originality in section 3A(2) CDPA 1988. A database "is original if, and only if, by reason of the selection or arrangement of the contents of the database the database constitutes the author's own intellectual creation". This is generally taken to be a higher level of originality than the traditional "skill, effort and labour" UK originality test"115, but it is rather unclear what this additional requirement of "intellectual creation" means"116.

The fact is that not everything that originates with the author will satisfy this originality test. The selection must involve a sufficient level of the author's individual creativity. How much creativity is required is not made clear and will with-

\footnotetext{
111 See also above Chapter 2.4.1.1.3.6.

112 Cf. G. Westkamp, Der Schutz von Datenbanken und Informationssammlungen im britischen und deutschen Recht, Munich, Beck, 2003, p. 204.

113 MacQueen, Waelde, Laurie and Brown, note 82 above, para. 2.56.

114 Directive 96/09/EC.

115 MacQueen, Waelde, Laurie and Brown, note 82 above, para. 2.57; cf. also Bainbridge, note 90 above, p. 280.

116 Unclear, e.g. MacQueen, Waelde, Laurie and Brown, ibid., para. 2.63; Bainbridge, ibid., pp. 280 et seq.
} 
out doubt vary from case to case, but the requirement imposes a significant qualitative factor on the test, requiring some subjective contribution by the author ${ }^{117}$.

In the case of a database of research data, the elements contained are usually pre-existing (results of an experiment etc.) and the individual who creates the database cannot choose which data he wants to fill the database, but has to use all data that is relevant in a specific context. The structure of the database has to be clear and based on the scientific needs. This does not leave much room for creativity and subjective contribution of the author. It follows that databases of research data are usually not protectable by copyright.

\subsection{Limitations}

The limitations on the restricted acts of the author or rightholder are almost the same as for other works and the fair dealing provisions apply to databases as they do to other literary works ${ }^{118}$.

In addition, section 50D CDPA 1988 states that it is not an infringement of copyright for a person who has the right to use the database to do, in the exercise of that right, anything that is necessary for the purpose of access to and use of the contents of the database. This right cannot be excluded. Section 296B CDPA 1988 states that any term in an agreement shall be void in so far as it purports to prohibit or restrict the performance of any act permitted under section 50D CDPA 1988.

\subsection{Sui generis right}

The second way to protect a database under UK law is the sui generis database right. This right was introduced by the Database Directive too, but differs from copyright protection. The UK implemented the database right in the Database Regulations 1997119. The purpose of copyright harmonised by the Directive is to provide encouragement for creative endeavour, and the sui generis right is designed to encourage investment in particular types of data gathering ${ }^{120}$. The database right thereby protects databases, which although they may fail to meet the requirements for copyright protection as a database, are commercially valuable, being the result of a substantial investment ${ }^{121}$. A copyright database is not precluded from also enjoying database rights ${ }^{122}$.

\footnotetext{
117 Cf. clearer, Copinger and Skone James on Copyright, note 93 above, vol. I, 3-148.

118 Bainbridge, note 90 above, p. 282.

119 Copyright and Rights in Databases Regulations 1997 (Sl 1997/3032).

120 Copinger and Skone James on Copyright, note 93 above, vol. I, 3-148.

121 Bainbridge, note 90 above, p. 282.

122 MacQueen, Waelde, Laurie and Brown, note 82 above, para. 6.5.
} 


\subsection{Requirements for protection}

According to regulation 12(1) Database Regulations 1997, the term database has the same meaning as in section 3A(1) CDPA 1988. Thus a database means a collection of independent works, data or other materials, which are arranged in a systematic or methodical way, and are individually accessible by electronic or other means. Since regulation 12(1) Database Regulations 1997 does not contain a reference to section 3A(2) CDPA 1988, it is clear that an intellectual creation is not required for the database right to arise.

Regulation 13 Database Regulations 1997 states that the "database right" (as a property right) subsists in a database if there has been a substantial investment in obtaining, verifying or presenting the contents of the database.

The ECJ held that resources used during the stage of creation of data or other materials that are subsequently collected in a database cannot be taken into account in order to assess whether there was substantial investment ${ }^{123}$. Therefore, a substantial investment in the creation of the database itself is required and not merely in the creation of the data.

The investment necessary for the existence of the database right may consist in the deployment of human, financial or technical resources but it must be substantial in quantitative or qualitative terms. The quantitative assessment refers to quantifiable resources and the qualitative assessment to efforts that cannot be quantified, such as intellectual effort or energy ${ }^{124}$. Even if this definition is not completely clear, it can be assumed that the investment does not have to be above average.

Thus, the protection requirements are much lower than for copyright protection. Most databases that match the technical criteria (systematically or methodically arranged/individually accessible elements) do require a minimum of investment and are protectable by the sui generis right.

These criteria are also usually met in the field of research databases. In the majority of cases, quantitative resources such as working time and financial expenses will be used (for example in the course of a scientific research project) to create the database as well as intellectual effort and energy of the person creating the database. Consequently, research databases are in general protected by the database right ${ }^{125}$.

\footnotetext{
${ }^{123}$ ECJ Case C-203/02, British Horseracing Board Ltd v William Hill Organization Ltd (BHB), [2004] ECR I-10415, para. 34.

${ }^{124}$ ECJ Case C-338/02, Fixtures Marketing Ltd v Svenska Spel AB, [2005] ECDR 4, 43, para. 28.

125 And this even if the main investment in the course of scientific research concerns the creation of data, as long as there is also a substantial investment in the creation of the database. Different, but not convincing: The study of Knowledge Exchange, Annex 4 - The legal status of research data in the United Kingdom, available at: http://www.knowledge-exchange.info/Default .aspx?ID=461 (last accessed 06/2013), p. 21.
} 


\subsection{Right owner}

According to regulation 15 Database Regulations 1997 the maker of a database is the first owner of a database right in it.

Regulation 14 Database Regulations 1997 defines the maker of a database as the person who takes the initiative in obtaining, verifying or presenting the contents and assuming the risk of investing in those activities. Thus, the maker of a database is not the natural person who creates it, but the person or entity which carries the financial risk to invest into the creation of the database.

Where a database is made by an employee in the course of his employment, his employer shall be regarded as the maker of the database (regulation 14(2) Database Regulations 1997).

\subsection{Scope of protection}

The sui generis database right has its own infringement regime distinct from that of copyright ${ }^{126}$. According to regulation 16 Database Regulations 1977, a person infringes the database right in a database if, without the consent of the owner of the right, he extracts or re-utilises all or a substantial part of the contents of the database. Extraction means the permanent or temporary transfer of those contents to another medium by any means or in any form, and re-utilisation means making those contents available to the public by any means ${ }^{127}$.

Basically, only the use of a substantial part infringes the database right. According to regulation 12(1) Database Regulations 1977 substantial means substantial in terms of quantity or quality or a combination of both.

The protection of the sui generis right through the exclusive rights of extraction and re-utilisation does not cover consultation of a database ${ }^{128}$; if the maker himself makes the contents of his database or a part of it accessible to the public, his sui generis right does not allow him to prevent third parties from consulting that base ${ }^{129}$. This means that as far as an extraction or re-utilisation is necessary to consult a database, this action is not covered by the database right, since according to the ECJ, the part of a database that has to be used to access a database does not form a substantial part of the database content.

Accepting that repeatedly taking insubstantial parts can compromise the owner's economic rights in a database, regulation 16(2) Database Regulations 1977 provides that the repeated systematic extraction or re-utilisation of insubstantial

\footnotetext{
${ }^{126}$ MacQueen, Waelde, Laurie and Brown, note 82 above, para. 6.12.

${ }_{127}$ Copinger and Skone James on Copyright, note 93 above, vol. V, pp. 18-28.

${ }^{128}$ ECJ Case C-203/02, British Horseracing Board Ltd v William Hill Organisation Ltd, [2005] ECDR 1, 1, para. 54.

${ }^{129}$ Ibid., para. 55.
} 
parts of the contents of a database may amount to the extraction or re-utilisation of a substantial part of those contents ${ }^{130}$.

\subsection{Limitations}

The limitations on copyright are not applicable to the database right. However, there are some separate exceptions to the database right mentioned in the Database Regulations 1997. The principal exceptions are for non-commercial research and teaching.

According to regulation 20 Database Regulations 1997 the database right in a database that has been made available to the public is not infringed by fair dealing with a substantial part of its contents for non-commercial research purposes; or if it is extracted for the purpose of illustration for teaching or research and not for any commercial purpose. It is important to note that these exceptions only allow extraction and not re-utilisation of substantial parts of a database.

Regulation 19 Database Regulations 1997 contains the provision that a lawful user ${ }^{131}$ of a database that has been made available to the public shall be entitled to extract or re-utilise insubstantial parts of the contents of the database for any purpose and that any contractual term that purports to prevent a person from extracting or re-utilising insubstantial parts will be void. The idea behind this regulation is that a person who has a contractual agreement with the rightholder shall not have fewer rights than any other lawful user.

Regulation 17 Database Regulations 1997 states that the right in a database expires at the end of the period of 15 years from the end of the year in which the making of the database was completed or in which the database was first made public.

However, any substantial change to the contents of the database which would result in the database being considered to be a substantial new investment shall qualify the database resulting from that investment for its own term of protection (regulation 17(3) Database Regulations 1997). A dynamic database could therefore end up with a rolling series of 15-year protections, which will keep the right alive so long as the owner thinks it worthwhile to continue investment in it ${ }^{132}$.

\subsubsection{Germany}

\subsubsection{Protection as a copyright work}

One possible form of protection of research data is copyright protection. However, it is questionable whether all forms of research data can be protected

\footnotetext{
${ }^{130}$ Bainbridge, note 90 above, p. 285.

131 A lawful user is defined in regulation 12(1) Database Regulations 1997 as a person who (whether under a licence or otherwise) has a right to use the database.

132 MacQueen, Waelde, Laurie and Brown, note 82 above, para. 6.11.
} 
by copyright. To be capable of copyright protection, the respective research data has to constitute a copyright work.

\subsection{The copyright work}

The German Copyright law (Urheberrechtsgesetz/UrhG) provides detailed conditions for the copyright protection of works.

\subsection{Kinds of work}

Article 2 I UrhG names the different kinds of copyright protectable works. These are: literary works, musical works, works in mime, works of graphic art, works of photography, film works and scientific and technical maps.

Even though this list is non-exhaustive ${ }^{133}$, it nevertheless provides an idea of what kinds of human creations copyright can protect; for example a written book or the sound of a song, a painted picture. All these works are artistic-creative creations.

\subsection{Work of authorship}

Since the list in Article $2 \mathrm{I}$ UrhG is non-exhaustive the real prerequisite for a copyright-protectable work is mentioned in Article 2 II UrhG. According to this, a work is protectable by copyright if it is an original personal creation. The requirements are: a personal creation, intellectual content, a certain form and individuality.

A personal creation means that the work has to be made by a person. Therefore, a picture painted by a monkey or a text written by a translating computer are not works in the sense of copyright.

In addition to that, the work must have a certain form. This does not mean that the work has to have a tangible form, but that it has to be noticeable to persons other than the author himself. A poem that exists only in the head of the poet is not protectable. It has at least to be vocalised so that other people can hear $\mathrm{it}^{134}$. Mere ideas are also not protectable ${ }^{135}$, but only the concrete form, in which an idea is expressed. A TV-show format for example is not copyright protectable, since the show format is merely an idea and not a visual form of a work ${ }^{136}$.

Intellectual content means that the work must be made to communicate in the widest sense. An intellectual creation occurs when the work has a thought- or emotional content which makes some kind of impression on the observer ${ }^{137}$.

\footnotetext{
133 Cf. A. Nordemann, in Fromm/Nordemann (eds), Urheberrecht, 10th edition, Stuttgart, Kohlhammer, 2008, \2, para. 11.

134 Example taken from ibid., para. 23.

${ }_{135}$ Cf. G. Schulze, in Dreier/Schulze (eds), UrbG, 3rd edition, Munich, Beck, 2008, \2, para. 37.

${ }_{136}$ Cf. BGH, GRUR 2003, 876 - Sendeformat.

${ }^{137}$ Cf. Schulze, note 135 above, $\$ 2$, para. 12.
} 
The last requirement for a protectable work, individuality, is the core principle of German copyright law. To examine individuality, two stages of examination are important: Does the work, when compared to work already known, show individual characteristics?; and: Does the work satisfy a certain level of originality and is it not the result of a routine work?

It is notable that the requirements for individuality are not too high. Even the "small coin" (kleine Münze) is protectable by copyright. However, at least a minimum of originality is required. This is particularly relevant for works of applied arts. It is, for example, not sufficient just to copy something that can be found in the environment as a work of pure artistic craftsmanship, without giving the work an individual character ${ }^{138}$.

Since research data can be every kind of data produced in the sphere of scientific research ${ }^{139}$, no general statement can be given about the copyright protection of this data. In all cases it depends on whether the work in question is an original personal creation or not. Copyright protection is especially relevant for the creation of scientific papers.

\subsection{Authorship and ownership}

According to Article 7 UrhG the author is the creator of the work. Since a personal creation is required ${ }^{140}$, the author of a work can only be a natural person ${ }^{141}$. All of the exclusive economic and moral rights refer to the author as the rightholder.

In German copyright law, it is impossible to transfer the copyright to another person; article $29 \mathrm{I}$ UrhG states that the copyright is unassignable. This means that the owner of the copyright is in every case the author.

However, as Article $31 \mathrm{I} \mathrm{UrhG} \mathrm{states,} \mathrm{it} \mathrm{is} \mathrm{possible} \mathrm{to} \mathrm{assign} \mathrm{"rights} \mathrm{of} \mathrm{use"} \mathrm{to}$ others. This granting of usage rights to others is often described as licensing, but it should be noted that there is no legal definition of the term "licence" in Germany. Therefore it is more precise to use the term "right of use".

The UrhG also contains some provisions regarding employee-authors. In general, the employee as a natural person is the author of a work which was created as part of his job ${ }^{142}$. Therefore, according to Article $43 \mathrm{UrhG}$, the employee remains the rightholder of all usage rights, unless the employment contract provides otherwise.

However, the regulation of Article $43 \mathrm{UrhG}$ is not as clear as it seems to be. In the first instance it seems that the author retains all of his rights. But the reality is that the employment relationship is almost always based on the granting of rights

\footnotetext{
138 BGH, GRUR 1995, 581, 582 - Silberdistel.

139 See above, Chapter 1.

140 Cf. above Chapter 2.4.2.1.1.2.

141 Cf. Schulze, note 135 above, $\int 7$, para. 2.

142 Cf. ibid., \ 7 , para. 8 and $\int 43$, para. 1.
} 
of use to the employer ${ }^{143}$. Thus, Article $43 \mathrm{UrhG}$ means the opposite of what it seems to say ${ }^{144}$ : generally, the employee grants rights of use to the employer automatically as far as needed for the exploitation of the work.

Article 69b I UrhG contains a specific rule for computer programs. This regulation is much clearer than Article $43 \mathrm{UrhG}$. If a computer program is created in the context of an employment relationship, the employer is entitled to exercise all of the economic rights, unless otherwise contractually agreed, which means that the employer usually has the relevant rights of use.

The regulations in Articles 43 and 69b UrhG are also applicable in public sector employment relationships. Article 43 and Article 69b II UrhG mention the term "Dienstverhältniss(e)", i.e. public sector employment relationships and not private law employment contracts $^{145}$, such as freelance agreements. Therefore it is crucial to make contractual arrangements regarding the granting of rights of use in such freelance agreements, since the employer does not get any rights automatically.

It should be noted that the author as the creator of the work is and remains in any case the owner of the copyright under German law. In an employment context, the employer is usually the owner of the rights of use as far as he needs them for the exploitation of the work. In the case of freelance agreements, it depends on the contractual regulations which rights are granted to the employer.

Provided that several authors have contributed to a copyright work, they are all co-authors of the work (Article $8 \mathrm{I}$ UrhG).

\subsection{Exclusive rights}

The exclusive rights of the author are mentioned in Articles 15 et seq.The author has the exclusive right of reproduction (Articles $15 \mathrm{I}$ no. 1, $16 \mathrm{UrhG}$ ), right of distribution (Articles $15 \mathrm{I}$ no. 2, $17 \mathrm{UrhG}$ ), right of exhibition (Articles $15 \mathrm{I}$ no. 3, $18 \mathrm{UrhG}$ ), and the right of communication to the public (Article $15 \mathrm{II} \mathrm{UrhG).} \mathrm{The}$ consent of the author or rightholder is required to exercise one or more of these actions.

\subsection{Right of reproduction (Articles 15 I no. 1, 16, 69c no. 1 UrhG)}

The right of reproduction gives the author or rightholder the exclusive right to reproduce a copyright work. The BGH defines a reproduction as any physical fixing of a work which is suitable to make the work directly or indirectly perceptible by the human senses ${ }^{146}$.

\footnotetext{
143 E.g. in the case of journalists, directors, translators, illustrators etc.

${ }^{144}$ Likewise Nordemann, note 133 above, \43, para. 1.

145 Cf. A.-A. Wandtke, in Wandtke/Bullinger (eds), Urbeberrecht, 3rd edition, Munich, 2009, \43, para. 14; and M. Grützmacher, in ibid., \$ 69b, para. 3.

146 Cf. BGH, GRUR 2001, 51, 52 - Parfumflakon.
} 
Reproduction is defined as a physical exploitation right. All reproductions that lead to a new physical fixation of a work are covered, regardless of the form used; for example, the copying of a book, the recording of a film or the storing of a computer program. The reproduction even covers the copying of only parts of a work, if copyright subsists in the copied parts themselves ${ }^{147}$. Thus every permanent or temporary, whole or partial, reproduction by any means, regardless of whether in digital or analogue form, falls within the scope of the term reproduction.

\subsection{Right of distribution (Articles 15 I no. 2, 17, 69c no. 3 UrhG)}

Another physical exploitation right is the right of distribution. This is the right to publicly offer or put into circulation the copyright-protected work or copies thereof. The offer or putting into circulation must aim at granting possession over the copy of work ${ }^{148}$. The classical acts of distribution are the offering for sale and the selling of goods. But rental and lending are also acts of distribution ${ }^{149}$. According to the prevailing opinion, the copy of work which is or shall be distributed must exist in a physical form. However, this changes at the moment, at least in relation to computer programs ${ }^{150}$.

An important limitation to this right is the "exhaustion of the distribution right". This principle is contained in Article $17 \mathrm{II} \mathrm{UrhG} \mathrm{and} \mathrm{provides} \mathrm{that} \mathrm{if} \mathrm{the}$ original or copies of a work were put into circulation by sale and with the permission of the holder of the distribution right, the further distribution of these copies is permitted. The background to this principle is that the free movements of goods shall not be hindered once they are lawfully distributed and the author has had the chance to be fairly remunerated for this.

\subsection{Right of exhibition (Articles $15 \mathrm{I}$ no. 3, $18 \mathrm{UrhG}$ )}

The right of exhibition is the right to exhibit originals or copies of an unpublished work of graphic art or photography to the public. In the context of research data, this right is of minor importance.

\subsection{Right of communication to the public (Articles 15 II, 69c no. 4 UrhG)}

The right of communication to the public is the right to use and exploit a copyright work in non-physical forms. In particular, it includes the right of recital, performance and presentation (Articles 15 II s. 2 no. 1, 19 UrhG), the right to make publicly available (Articles 15 II s. 2 no. 2, 19a UrhG), the broadcasting right

\footnotetext{
147 Cf. Schulze, note 135 above, \16, para. 9.

148 The granting of ownership over the copy of work is not necessary; misleading in this respect

BGH, NJW 2009, 2960 - Le-Corbusier-Möbel II; cf. N. Dietrich, 'Was wird aus dem urheberrechtlichen Verbreitungsrecht?', UFITA 2011-II, 478 et seq.

${ }^{149}$ Cf. Article 17 II and III UrhG for renting; for both see Schulze, note 135 above, \17, para. 15.

150 Cf. ECJ Case C-128/11, Oracle v UsedSoft, [2012] NJW 2012, 2565.
} 
(Articles $15 \mathrm{II}$ s. 2 no. 3, $20 \mathrm{UrhG}$ ), the right to render through a picture or sound carrier (Articles $15 \mathrm{II} \mathrm{s.} 2$ no. 4, $21 \mathrm{UrhG}$ ) and the right of communication of broadcasts and to make publicly available (Articles $15 \mathrm{II}$ s. 2 no. 5, 22 UrhG).

The most important right in the context of research data is the right to make the work publicly available. Article $19 \mathrm{a}$ UrhG gives the author the exclusive right to make the work available to the public by wire or wireless means in such a way that it is available to public users in places and at times of their own choosing.

The right is neutrally formulated with respect to technology; however, it is closely related to the internet ${ }^{151}$; it was included in the UrhG in 2003 with the objective of closing gaps in connection with the online exploitation of intellectual works ${ }^{152}$.

In this context, "publicly available" is understood as intended to be accessible to more than one member of the public. The term public covers everyone who is not connected by personal relationship with the person exploiting the work or with other people to whom the work is made accessible (Article $15 \mathrm{III} \mathrm{UrhG).}$

The most relevant form of making publicly available is the publishing of data in information networks (for example, but not only, the internet). The consent of the author or rightholder is always required when the work is to be used in information networks.

\subsection{Right of adaptation (Articles 23, 69c no. $2 \mathrm{UrhG}$ )}

A copyright work can be adapted without the consent of the author. However, according to Article 23 s. 1 UrhG the exploitation of a modified or adapted work is not allowed without the consent of the author.

\subsection{Limitations}

The exclusive rights of the author or rightholder are subject to some limitations.

At first it should be noted that copyright just protects the respective manifestation of a work and not the ideas behind it; bare data and facts are not protected by copyright ${ }^{153}$. Therefore, it is possible to copy bare facts of a work and express them in one's own words. Furthermore, there is no copyright infringement if there is no copyright existing in the used part of a work.

An important limitation in the scientific context is the right of quotation which is provided through Article $51 \mathrm{UrhG}$. The use of another author's work is permitted when it is used for the purpose of quotation to the extent necessary for this purpose in another copyright protectable work.

Another relevant limitation is the right of copying a work for personal use or one's own scientific purposes (Article $53 \mathrm{UrhG}$ ). A use may be regarded as private

\footnotetext{
${ }^{151}$ Cf. W. Bullinger, in Wandtke/Bullinger (eds), note 145 above, $\ 19 \mathrm{a}$, para. 2.

152 Cf. A. Dustmann, in Fromm/Nordemann (eds), note 133 above, $\$ 19 a$, para. 1.

${ }^{153}$ Cf. Schulze, note 135 above, $\ 2$, para. 130.
} 
if it belongs to the domestic sphere or circle of family and friends ${ }^{154}$; and scientific in the context of a scientific activity ${ }^{155}$. In both cases it is only permitted to make single copies of a work ${ }^{156}$.

The copyright expires 70 years after the death of the author (Article 64 UrhG).

\subsubsection{Protection as databases}

A special, and maybe the most important kind of research data, are databases. Research databases can contain almost every kind of data, journal articles or abstracts, metadata, raw research data etc. Databases may be copyright protectable, but also protectable by another right, the sui generis database right.

\subsection{Copyright protection of collections/databases}

The UrhG contains a special provision in Article 4 on the copyright protection of collections and databases. This regulation is just a clarification and definition of these categories of work. The protection of such works has already been possible for the open catalogue of works of Article $2 \mathrm{I} \mathrm{UrhG}^{157}$. Therefore, the requirements for copyright protection, ownership and the exclusive rights of such works are the same as for other work categories ${ }^{158}$.

\subsection{Collections and databases}

According to Article $4 \mathrm{I}$ UrhG, a collection of data can be protected by copyright if it consists of works, data or other independent elements which, by reason of the selection or arrangement of the elements, represent a personal intellectual creation. A sub-case of a collection is a database work. A database work is a collection whose elements are arranged systematically or methodically and individually accessible by electronic or other means (Article 4 II UrhG).

\subsection{Original personal creation}

For the copyright protection of a collection it is irrelevant whether or not the individual elements contained in the collection can be protected as copyright works as well. What is relevant is whether the collection itself constitutes a personal intellectual creation ${ }^{159}$. This means that even if the research data contained in a database are not capable of being protected by copyright, it is still possible that the database itself is protectable.

\footnotetext{
154 Cf. W. Nordemann, in Fromm/Nordemann (eds), note 133 above, \ 53, para. 6.

155 "Scientific" means an activity that is taught at universities; cf. ibid., $\int 53$, para. 19; with a broader definition: Schulze, note 135 above, $\int 53$, para. 23.

156 This means no more than seven copies, cf. BGH, GRUR 1978, 474 - Vervielfältigungsstücke.

157 Cf. Schulze, note 135 above, \ 4, para. 1.

158 See above Chapter 2.4.2.1.

${ }^{159}$ Cf. Schulze, note 135 above, \4, para. 4.
} 
However, the protection requires a personal intellectual creation. Therefore, the selection or arrangement of the database elements must constitute an intellectual creation and the work must have reached a certain level of originality ${ }^{160}$. The meaning of the content must go beyond the mere sum of the data elements contained. For protection as a database work it is necessary that the collection has an individual character in its structure, which is created by the selection or arrangement of its content ${ }^{161}$.

In the case of research data, collections and databases will usually not be protectable by copyright ${ }^{162}$. The elements contained are usually pre-existing (results of an experiment etc.). The aim of a database in such a context is a clear and flexible presentation of the data. Therefore the individual cannot choose which data he wants to fill the database, but has to use all data that is relevant in a specific context. The structure of the database has to be clear and based on the scientific requirements. This does not leave much room for creativity or individual choices of the creator of a database for research data. It follows that collections and databases of research data are usually not protectable by copyright.

\subsection{Limitations}

In general, copyright does not protect mere ideas. This is also the case for copyright protection of databases; the idea behind the database is not protectable, but only the concrete form of the database work ${ }^{163}$.

The limitations on the exclusive rights of the author/rightholder are almost the same as for other works. However, there is one important exception in Article $53 \mathrm{~V}$ UrhG, which states that the right of copying a work for personal use is not applicable for electronic databases. But according to Article 55a UrhG the authorised user is allowed to make copies of a database work if these are necessary for the normal use of the database.

Furthermore, Article 23 s. 2 UrhG states that not only the exploitation of an adaptation of a database work is illegal without the consent of the author, but also the creation of an adaptation itself.

\subsection{Sui generis right}

Databases can enjoy not only copyright protection, but also protection under the sui generis right for databases. The database right is based on Directive 96/09/EG, which implemented this right in the EU. The database right is contained in Arti-

\footnotetext{
160 See above Chapter 2.4.2.1.1.2.

161 BGH, MMR 2007, 589 - Gedichttitelliste I.

162 Likewise: The study of Knowledge Exchange, Annex 3 - The legal status of research data in Germany, available at: http:/ /www.knowledge-exchange.info/Default.aspx?ID=461 (last accessed 06/2013), p. 14.

163 Cf. M. Leistner, Der Rechtsschutz von Datenbanken im deutschen und europäischen Recht, Munich, Beck, 2000 , p. 281.
} 
cles $87 \mathrm{a}$ et seq. UrhG. Although it is part of the UrhG, the database right is not a copyright, but a neighbouring right, which is independent of the existence of a copyright ${ }^{164}$. This means that a database can be protected by copyright and the database right at the same time.

\subsection{Requirements for protection}

The requirements for protection as a database are listed in Article 87a I s. 1 UrhG. According to that provision, the database has to be systematically or methodically arranged, the elements of the database have to be individually accessible and the database has to have required a substantial investment. The first two requirements are merely of a technical character; the most important requirement is the substantial investment.

It is important that a substantial investment in the creation of the database itself is necessary. It is not sufficient to invest only in the creation of the data ${ }^{165}$.

To obtain database protection, the investment in the creation of the database does not have to be above average. Only totally insignificant expenditure that can be made by anyone is insufficient ${ }^{166}$. Thus, even personnel expenses for review and assessment of the data may be sufficient ${ }^{167}$. Thus, protection requirements are low. Most databases that match the technical criteria (systematically or methodically arranged/individually accessible elements) do require a minimum of investment and are protectable by the sui generis right. Also in the field of research databases, these criteria are usually met. Consequently, research databases are mostly protected by the database right.

\subsection{Right owner}

The owner of the database right is the database maker ("Datenbankhersteller"); this is the person who has made the substantial investment in the creation of the database (Article 87a II UrhG). Unlike copyright, the owner of the database right does not have to be a natural person, but can be a legal person as well ${ }^{168}$.

The right owner is not the person who collects, examines and systematically arranges the data, but instead the person or entity which has made the investment in the database creation ${ }^{169}$, or in other words the risk carrier of the economic decision to invest in the creation of the database ${ }^{170}$. This means that in an employment relationship the employer is usually the owner of the database right.

\footnotetext{
${ }^{164}$ Cf. T. Dreier, in Dreier/Schulze (eds), note 135 above, $\iint 87$ a et seq., para. 8.

165 Cf. D. Thum, in Wandtke/Bullinger (eds), note 145 above, \87a, para. 36; ECJ Case C-338/02, Fixtures Marketing Ltd v Svenksa AB (Svenska), [2004] ECR I-10497, para. 24; BGH, GRUR 2005, 857, 858 - HIT BILANZ.

166 Cf. BGH, MMR 2011, 676, para. 23 - Zweite Zahnarztmeinung II.

167 Cf. BGH, MMR 2011, 676, para. 21 - Zweite Zahnarztmeinung II.

${ }_{168}$ Cf. Leistner, note 163 above, p. 304.

${ }^{169}$ Cf. Thum, in Wandtke/Bullinger (eds), note 145 above, $\$ 87$ a, para. 134.

${ }^{170}$ Cf. Westkamp, note 112 above, pp. 406 et seq.
} 


\subsection{Scope of protection}

It should be noted that the database right does not protect the data itself, but the investment in the creation of the database. However, this investment is protected by giving the right owner the exclusive right to exploit the database.

Basically, the exclusive rights of the right owner correspond to the common exploitation rights of a copyright owner ${ }^{171}$. The exclusive rights are named in Article $87 \mathrm{~b}$ UrhG. The producer has the right to copy, distribute or make available to the public the entire database or any substantial part of it (Article 87b I s. 2 UrhG).

Just the extraction/use of a substantial part is not allowed without the permission of the rightholder. To commit an infringement, a qualitatively or quantitatively substantial part of the database has to be extracted. Whether a part is substantial or not is decided on a case-by-case basis. In quantitative terms, the BGH has held the extraction of $75 \%$ of the data to be a substantial part ${ }^{172}$ and the extraction of $10 \%$ not to be substantial 173 . However, according to the ECJ even a quantitatively insubstantial part can be of a substantial nature if this part is of importance for the investment in the database creation ${ }^{174}$. And in the Autobabnmaut decision, the BGH held that even the making available of the datasets of single users to those users is a relevant act if this is the main utilisation of the database, and the users altogether belong to the public sphere ${ }^{175}$.

In general, the exclusive rights of the right owner are not affected by the use of insubstantial parts of the database. Thus querying a database is allowed. This was also held by the ECJ in its $B H B$ decision in which it held that the protection of the sui generis right through the exclusive rights of extraction and re-utilisation does not cover consultation of a database ${ }^{176}$.

Since the use of insubstantial parts of a database is generally possible without the consent of the database producer, it would be possible to extract systematically many insubstantial parts and rearrange them in order to get a substantial part as the final result. To prevent this circumvention, Article 87b I s. 2 UrhG contains the provision that the exclusive rights also apply if non-substantial parts of the database are repeatedly and systematically copied, distributed or made available to the public in a way that is contrary to a normal utilisation of the database.

\footnotetext{
171 Cf. Leistner, note 163 above, p. 308.

172 Cf. BGH, MMR 2010, 41 - Gedichttitelliste III.

173 Cf. BGH, MMR 2011, 676 - Zweite Zahnarztmeinung II.

174 Cf. ECJ Case C-203/02, British Horseracing Board Ltdv William Hill Organization Ltd (BHB), [2004] ECR I-10415, para. 71.

175 Cf. BGH, MMR 2011, 188 - Autobahnmaut.

176 ECJ Case C-203/02, British Horseracing Board Ltd v William Hill Organization Ltd (BHB), [2004] ECR I-10415, para. 54.
} 


\subsection{Limitations}

The limitations on copyright are not applicable to the sui generis right. Article 87c UrhG contains a definitive list of limitations on the database right ${ }^{177}$. According to this provision, the copying of a substantial part of a database is allowed for one's own private or scientific use and the purpose of illustration for teaching. Furthermore, copying, distribution or communication to the public is permitted, in a lawsuit or a proceeding involving authorities and for public security uses. Since the regulation of Article $87 \mathrm{c} \mathrm{UrhG}$ is not entirely clear on this issue, it is important to note that the limiting provisions of database protection only apply to databases that have been published ${ }^{178}$.

Article 87 e UrhG contains a provision that the rightholder cannot contractually exclude the lawful user from the reproduction, distribution or communication to the public of insubstantial parts of the database. The background for this is that even someone who has no contractual agreement with the rightholder has the right to do these acts in relation to the database.

According to Article 87d s. 1 UrhG, the exclusive rights of the database producer expire 15 years after the publication of the database; and if the database was not published, 15 years after the creation of the database. However, it is important to be aware that a significantly modified database is regarded as a new database if the modifications require a substantial investment (Article 87a I s. 2 UrhG). The reason for this is that a new substantial investment shall be protected too. On the other hand, this means that the protection begins again. Thus the database right does not always expire after 15 years, but can be extended with every new substantial investment - possibly endlessly.

\subsubsection{The Netherlands}

\subsubsection{Protection under the Copyright Act}

\subsection{The work}

Whereas scientific publications virtually always attract copyright protection under the copyright laws of the Member States of the European Union, the individual research data and the datasets containing them may not so easily fall under the copyright regime. Since copyright does not protect mere facts and ideas, but rather attaches to the original expression of ideas, research data is not likely to qualify as protectable subject matter for lack of originality. Article 10 of the Dutch Copyright Act (DCA) contains a non-exhaustive list of categories of works that are literary, scientific and artistic works, and are protected under the DCA provid-

177 Cf. ibid., para. 62.

178 Cf. Leistner, note 163 above, p. 313; Thum, in Wandtke/Bullinger (eds), note 145 above, \87c, para. 7. 
ed they are sufficiently original. This includes original adaptations (Article 13 DCA). The criterion of originality is not specified in the Act but has been recognised as a requirement for protection by the courts in several cases ${ }^{179}$. "Originality" (or "oorsponkelijkheid") is in Dutch practice typically used as shorthand for a two-pronged test elaborated by the Supreme Court. The work must have an "own, individual character" and "bear the personal stamp of the author"180.

Dutch copyright law contains special provisions for two categories of works: geschriften (written works) and posthumous works, of which only the geschriften are of interest here. The special regime for written works is not laid down as such in the Copyright Act, but is derived from the case law of the Supreme Court, which interpreted the expression "other writings" as including texts devoid of original character. Not all non-original writings fall under this regime: to be protected, a non-original writing must be published or be destined to be published. The protection conferred is more limited in scope than under the normal copyright regime however; it is more akin to an unfair competition regime, for a claim for infringement of the regime on written works is admissible only against direct and (almost) complete copying. To limit the bounds of this regime, the Copyright Act specifies that computer programs and sui generis databases are not "writings" within the meaning of Article 10(1)(1) of the Copyright Act. Therefore, non-original software does not fall under this protection regime. By contrast, non-original databases have been recognised as impersonal writings, but only if they do not qualify for sui generis protection due to a lack of substantial investment in the obtaining, verification or presentation of the contents.

Following the Football Dataco decision of the ECJ ${ }^{181}$, however, it became clear that the gescbriftenbescherming no longer fitted within the European framework. Consequently, the Dutch government recently introduced a bill to repeal the geschriftenbescherming from the Copyright Act. If adopted, this abrogating Act will bring the Dutch database protection in line with the European standard, e.g. copyright protection for original databases and sui generis protection for databases showing a substantial investment in the collection, verification or presentation of the content of the database.

\footnotetext{
${ }^{179}$ Dutch Supreme Court, January 1991, NJ 1991, 608, m.nt. DWFV, AA 1992, 31 m.nt. HCJ, IER 1991, 96 m.nt. FWG, AMI 1991, 177 m.nt. JHS, CR 1991, 84 m.nt. Hugenholtz (Van Dale/Romme I).

180 See: M. van Eechoud, P. Bernt Hugenholtz, S. van Gompel, L.Guibault, and B. van der Sloot, 'Dutch report', ALAI Study Days, Dublin, June 2011, p. 1.

${ }^{181}$ ECJ Case C-604/10, Football Dataco Ltd et al v Yahoo! UK Ltd, [2012] GRUR 2012, 386.
} 


\subsection{Exclusive rights}

Under the DCA, all exclusive rights of the author are governed by either one of two broad concepts: the right to make a reproduction, or "verveelvoudiging", pursuant to Article $13 \mathrm{DCA}$ and the right to communicate to the public, or "openbaarmaking", pursuant to Article 12 DCA.

The right to make a reproduction encompasses two elements: the right to make copies of a work of authorship, and the right to make adaptations, arrangements, interpretations, translations, or any form of conversion of the work into another work. Actually Article 13 of the Act only refers to the second element of the right of reproduction. Because the issue was so obvious to the Dutch legislator, the first element of the right of reproduction is nowhere explicitly provided for in the Act. However, Article 14 of the DCA specifies for more certainty that "the reproduction of a literary, scientific or artistic work includes the fixation of the whole or part of the work on an object, which is intended to play a work or to show it".

The right to communicate to the public generally covers all acts by which a work can be communicated, distributed or made available to the public, including the first disclosure of the work or of adaptations of the work, the distribution of copies of the work, and the acts of playing, displaying, reciting the work etc.

According to the Dutch legislator, the concept of reproduction already included the right of reproduction described in Article 2 of the Info Directive, while the concept of communication to the public was broad enough to encompass both the right of communication to the public of Article 3 and the distribution right of Article 4 of the Directive. The implementation of the Info Directive has therefore not resulted in any modification of the provisions relating to the author's exploitation rights in the DCA.

Since the reproduction right under Article 13 of the Act focuses on the making of copies, it has generally been recognised in case law and literature that offering links, even deep links, to websites is not an act of reproduction ${ }^{182}$. However, it is generally considered unlawful under the general law of torts to provide links if one actually knows or should have reason to know that the links lead to illicit content.

\subsection{Exceptions and limitations}

Chapter 6 of the DCA contains numerous limitations exceptions allowing unauthorised use of protected works for different purposes, by different types of users and under different conditions. The most relevant in the context of this study are

\footnotetext{
182 District Court of The Hague, 20 December 2006, (Kunstenares v CU2), IEPT 2006-12-20; Court of Appeal of Den Bosch, 12 January 2010, (C More v MyP2P), IEPT 2010-01-12; District Court of Amsterdam, 12 September 2012, (Sanoma v GeenStij) IEPT 2012-09-12.
} 
the right of quotation (Article 15a), the right to use works communicated by or on behalf of a public authority (Article 15b), and the educational use exception (Article 16).

Before the implementation of the Info Directive, Article 15a of the Copyright Act 1912 stated that quotations were allowed in "an announcement, criticism, polemic or scientific treatise" as long as the conditions set out in the Article were met $^{183}$. For many authors, the circumstances listed in the Act are the most controversial element of the provision. Such restriction on the scope of the limitation appeared strange not only in light of the neutral concept of "quotation", but also in light of social reality. The quotation right of Article 15a has therefore been updated. A quotation is now permissible not only in "an announcement, criticism or scientific treatise", but also in a "publication for a comparable purpose". The scope of the quotation exception is restricted under Article 5(3)(d) of the Info Directive in the following ways:

a) the work quoted from must have been published lawfully;

b) the quotation is to be commensurate with what might reasonably be accepted in accordance with social custom and the number and size of the quoted passages are justified by the purpose to be achieved;

c) as far as reasonably possible the source, including the author's name, is to be clearly indicated.

This was already stated as such in the DCA. The requirement that moral rights are to be observed, not prescribed by the Directive, was maintained as well. According to Article 15a(2) the term "quotations" shall also include quotations in the form of press summaries from articles appearing in a daily or weekly newspaper or other periodical.

Unique to the DCA and relevant in the context of scientific works produced or disseminated by or on behalf of public authorities is Article 15b, which reads as follows:

183 Article 15a of the DCA reads as follows:

"Quotations from a literary, scientific or artistic work in an announcement, criticism or scientific treatise or publication for a comparable purpose shall not be regarded as an infringement of copyright, provided that:

10. the work quoted from has been published lawfully;

2o. the quotation is commensurate with what might reasonably be accepted in accordance with social custom and the number and size of the quoted passages are justified by the purpose to be achieved;

3o. the provisions of Article 25 are observed; and

4o. so far as reasonably possible the source, including the author's name, is clearly indicated.

2. In this Article the term 'quotations' shall also include quotations in the form of press summaries from articles appearing in a daily or weekly newspaper or other periodical.

3. This Article shall also apply to quotations in a language other than the original.". 
"The further communication to the public or reproduction of a literary, scientific or artistic work communicated to the public by or on behalf of the public authorities shall not be deemed an infringement of the copyright in such a work, unless the copyright has been explicitly reserved, either in a general manner by law, decree or ordinance, or in a specific case by a notice on the work itself or at the communication to the public. Even if no such reservation has been made, the author shall retain the exclusive right to have appear, in the form of a collection, his works which have been communicated to the public by or on behalf of the public authorities."

This exception is barely invoked in practice and has led since its introduction in the Copyright Act in 1975 to only three judicial decisions ${ }^{184}$. In the Internetnotarissen case, the Court of Appeal of Arnhem ruled that a "public authority" pursuant to Article 15b of the Copyright Act is to be understood as a body entrusted with regulatory authority, e.g. one that has a statutory power to make binding rules ${ }^{185}$.

Another exception that is relevant to the use and dissemination of scientific works is the educational use exception. Long before the implementation of the Directive, the DCA allowed the "taking over of parts of works" for teaching purposes, pursuant to Article 16. Article 16 \ 1 a gave examples of possible acts falling under the scope of the exception, such as the taking over in publications and sound or visual recordings and according to $\int 1 \mathrm{~b}$ radio or television programmes. Whether these means of reproduction included digital reproduction or online communication was highly uncertain. As a result of the implementation of the Directive, Article 16 of the DCA has been made technology-neutral/independent, so that digital reproductions also are covered as well as acts of making a work available to the public. Accordingly, all reproductions and communications that comply with the conditions set out in the article are in principle covered.

Notably, Article 16 of the DCA contains three additional criteria that do not appear in Article 5(3)(a) of the Directive:

a) the work from which the part is taken must have been published lawfully;

b) the adoption must be in accordance with what might reasonably be accepted under the rules of social custom;

c) moral rights have to be observed.

In addition, educational use requires that the source of the work used be indicated. Furthermore, and in contrast to the Directive, educational uses have always been

184 Supreme Court, 14 June 1968, NJ 1968, 276 (DNB v C\&A, Telegraaf- Bankbiljet'); Supreme Court, 29 May 1987, NJ 1987, 1003 (Struycken \& Unger v Riet - Beatrix Zegel); Court of Appeal Arnhem, 24 June 2008, Computerrecht 2008, 138 (Openbareverkopen.nl v Internet notarissen) with comment O. Volgenant.

185 B. Hugenholtz, A. Quaedvlieg and D. Visser, A Century of Dutch Copyright Law, Amsterdam, DeLex, 2012, pp. 141-75, p. 155. 
and remain permissible under Dutch law provided that an equitable remuneration is paid to the rights owners. It has been and still is up to the user (the institution) to make a timely offer of equitable compensation to the rightholder; equitability is estimated in terms of what is accepted in the line of business at hand.

Before the implementation of the Info Directive, all institutions that provided materials made for use as illustration for teaching purposes could benefit from the teaching exception. This included commercial institutions, for instance companies that published educational books. "Teaching" was to be interpreted broadly. To comply with the requirements of the Directive, Article 16 of the DCA has been modified to specify that the taking over from parts of work shall not be deemed an infringement of copyright only to the extent justified by the intended, noncommercial purposes. The meaning of non-commercial is not quite clear yet, but according to the Minister of Justice the nature of the activity of taking over the protected material is decisive. If this activity only takes place with the intention of using the material exclusively for teaching purposes, it will be covered by the exception of Article 16. Recital 42 of the Directive stresses that organisation and means of funding of the education institute is not decisive. Agreements between right owners themselves and between right owners and users of copyrightprotected material will have to determine the line between commercial and noncommercial use according to the Minister.

\subsubsection{Protection under the Database Act}

The provisions on the sui generis database right in the EU Database Directive have been transposed in a separate piece of legislation, the Dutch Database Act. This Act contains nine articles that closely follow the wording of the Directive, but augmented by a series of definitions (Article 1), provisions prohibiting the circumvention of effective technological protection measures (Article 5a) and the removal of rights management information (Article 5b), and a special provision on the exercise of rights on databases produced by or on behalf of public authorities (Article 8).

\subsection{Requirements for protection}

Pursuant to Article 1a of the Database Act, and in conformity with the Database Directive, a database is protected if it constitutes "a collection of independent works, data or other materials arranged in a systematic or methodical way and which elements are individually accessible by electronic or other means and for which the acquisition, control or presentation of the contents, evaluated qualitatively or quantitatively, bears witness to a substantial investment". Unconvinced of the need to grant protection for databases beyond what the Dutch copyright regime already provided for (original databases and geschriftenbescherming), Dutch courts have tended, since the very adoption of the Database Act, to interpret the requirement of "substantial investment" rather restrictively. Before the 
ECJ rendered its decision in the British Horseracing Board case, the Dutch Supreme Court had elaborated the spin-off doctrine, according to which the production of a database did not show any substantial investment if it merely derived from an enterprise's main activity, such as the making of a television programme listing by a broadcaster, or of a telephone book by a telecommunication service provider ${ }^{186}$. Since the ECJ's decision, Dutch courts have followed the ECJ's creation/collection dichotomy and are in general reluctant to conclude that there has been a substantial investment in the absence of clear evidence put forward by the alleged rightholder that he incurred substantial costs in either collection, verification or presentation of the content of the database ${ }^{187}$.

\subsection{Rights owner}

The beneficiary of the protection is not defined in the Dutch Database Act. There is therefore no reference in the Act to any kind of risk of investing. Dutch commentators seem to agree, however, that the sui generis right "should only be conferred as a reward for the risks taken by the innovating industry which actually produce the databases, not the commissioning parties ${ }^{188}$. Other commentators posit that employees, subcontractors or anyone else executing the work without bearing the financial responsibility for the end product cannot be considered as database rightholders ${ }^{189}$.

The Database Directive is silent on the issue of the source of the funding or the role of public money in the acquisition of rights. The Netherlands is so far the only Member State to have explicitly regulated the exercise of the sui generis rights by public sector bodies. Article 8 of the Dutch Database Act denies a public authority the right to exercise its exclusive database rights unless the right is reserved explicitly by a general mention in an act, order or ordinance, or in a specific case by notification on the database itself or while the database is made available to the public.

186 NVM v. De Telegraaf, decision of the Supreme Court of the Netherlands, 22 March 2002. Case C01/070HR. See: P.B. Hugenholtz, 'Program Schedules, Event Data and Telephone Subscriber Listings under the Database Directive - The 'Spin-Off Doctrine in the Netherlands and elsewhere in Europe', paper presented at Eleventh Annual Conference on International IP Law \& Policy, Fordham University School of Law, New York, 14-25 April 2003.

${ }^{187}$ Case where substantial investment was found to exist: Court of Appeal of Arnhem, (Openbareverkopen v Internetnotarissen), IEPT 2008-06-24; cases where no substantial investment was found to exist: Court of Appeal of Arnhem, 4 July 2006, (NVMv Zoekallehnizen), IEPT 2006-06-04; Court of Appeal of The Hague, (KNMP v ID/Farma) IEPT 2008-07-10; Court of Appeal of Amsterdam, (PR Aviation v Ryanair), IEPT 2012-03-13.

188 A. Beunen, Protection for databases - The European Database Directive and its Effects in the Netherlands, France and the United Kingdom, Nijmegen, Wolf Legal Publishers, 2007, p. 150.

189 J.H. Spoor, D.W.F. Verkade and D.J.G. Visser, Auteursrecht, 3rd edition, Deventer, Kluwer, 2005, p. 625. 
The specific question of the impact of public funding on the nature of the investment made to produce a database was the object of a ruling from the Raad van State (Dutch Council of State) in the Landmark case ${ }^{190}$. The case involved the interpretation of an article about the reuse of public sector information. A private company called Landmark, specialising in geographical information, had requested environmental information from the local authorities. Among the information was a list of addresses where soil research had taken place. The question in this case was whether the local authorities of Amsterdam were authorised to impose conditions and restrictions for the reuse of the list of addresses. Article 11a sub 1a of the Public Administration Act imposes two conditions on public bodies' ability to rely on the reuse regulation. First of all, a database must be present and secondly the public sector body has to qualify as the producer of the database. The court noted that the definition of "the database" and "the producer of the database" should be interpreted in the same way as in the context of the Dutch Database Act.

At first instance, the District Court of Amsterdam ruled that the City Council did not qualify as a "producer of a database" and therefore did not own any database right in the information it gathered, since the collection of data occurred in the performance of its public task and with the support of governmental subsidies; the database was indeed realised thanks to public funds, partially coming from the Ministry of Housing, Spatial Planning and Environment. Referring to Recital 41 of the Database Directive, the Court considered that the City Council did not qualify as a producer of the database because it did not actually bear the risk of the investment since public funding and government subsidies could not be equated to an investment that needed to be recouped on the market ${ }^{191}$. The Court stated that the database was made with the intention to simplify/facilitate the public task of the local authorities. Furthermore, the production of the database was initiated and financed by the local authorities of Amsterdam, a large part of which was financed by the Ministry of Housing, Spatial Planning and the Environment to fulfil the task of mapping local soil pollution. In these circumstances the Court found that the local authorities did not carry the risk of the substantial investment for the production of the database. Therefore, the Court came to the

190 ABRvS 29 April 2009, n 07/786, AMI 2009-6 (College B\&W Amsterdam/Landmark; with annotation from M. Van Eechoud).

191 The Court also made reference to the ECJ Case C-304/07, Directmedia Publishing GmbH v AlbertLudwigs-Universität Freiburg (Directmedia), [2008] MMR 2008, 807, in which the Court declared that the purpose of the database right is "to guarantee the person who has taken the initiative and assumed the risk of making a substantial investment in terms of human, technical and/or financial resources in the obtaining, verification or presentation of the contents of a database a return on his investment by protecting him against the unauthorised appropriation of the results of that investment by acts which involve in particular the reconstitution by a user or a competitor of that database or a substantial part of it at a fraction of the cost needed to design it independently". 
conclusion that the local authorities of Amsterdam could not be qualified as the producer of the database of which the list of addresses was part ${ }^{192}$. This ruling was confirmed on 29 April 2009 by the Raad van State. The Dutch position is so far unique within the EU.

\subsection{Exclusive rights}

In conformity with the Database Directive, the producer of a database enjoys under Article 3 of the Dutch Database Act the exclusive right to authorise the following acts: (a) the extraction or re-utilisation of all or a substantial part of the content of the database, evaluated qualitatively or quantitatively; and (b) the repeated and systematic extraction or re-utilisation of insubstantial parts of the content of a database, evaluated qualitatively or quantitatively, where this conflicts with the normal exploitation of that database or unreasonably prejudices legitimate interests of the producer of the database. Dutch courts have been called upon on a number of occasions to rule in cases of alleged infringement of the sui generis database right, and to determine whether an act of extraction was substantial or not.

The most interesting dispute to have reached the courts so far concerns the question of whether a daily search of a database by a dedicated search engine amounts to an unlawful repeated and systematic act of extraction and re-utilisation of that database. The Court of Appeal of The Hague referred questions for preliminary ruling to the ECJ to determine the scope of protection offered by the Database Act in relation to acts of extraction and re-utilisation through a dedicated meta search engine ${ }^{193}$. The Court of Appeal posed the following nine questions to the ECJ:

(1) Is Article 7(1) of the Directive to be interpreted as meaning that the whole or a qualitatively or quantitatively substantial part of the contents of a database offered on a website (on line) is re-utilised (made available) by a third party if that third party makes it possible for the public to search the whole contents of the database or a substantial part thereof in real time with the aid of a dedicated meta search engine provided by that third party, by means of a query entered by a user in 'translated' form into the search engine of the website on which the database is offered?

(2) If not, is the situation different if, after receiving the results of the query, the third party sends to or displays for each user a very small part of the contents of the database in the format of his own website?

\footnotetext{
192 ABRvS 29 April 2009, n 07/786, AMI 2009-6 (College B\&W Amsterdam/Landmark; with annotation from M. van Eechoud).

193 Reference for a preliminary ruling from the Gerechtshof's Gravenhage (Netherlands) lodged on 30 April 2012 - Innoweb B.V. v Wegener ICT Media B.V., Wegener Mediaventions B.V. (Case C202/12).
} 
(3) Is it relevant to the answers to Questions 1 and 2 that the third party undertakes those activities continuously and, with the aid of its search engine, carries out daily a total of 100000 queries received from users in 'translated' form and makes available the results thereof to various users in a manner such as that described above?

(4) Is Article 7(5) of the Directive to be interpreted as meaning that the repeated and systematic re-utilisation of insubstantial parts of the contents of the database which conflicts with normal exploitation or unreasonably prejudices the legitimate interests of the maker of the database is not permissible, or is it sufficient for there to be repeated or systematic re-utilisation?

(5) If repeated and systematic re-utilisation is a requirement,

(a) What does 'systematic' mean?

(b) Is re-utilisation systematic when an automated system is used?

(c) Is it relevant that a dedicated meta search engine is used in the manner described above?

(6) Is Article 7(5) of the Directive to be interpreted as meaning that the probibition for which it provides does not apply if a third party repeatedly makes available to individual users of a meta search engine belonging to that third party only insubstantial parts of the contents of the database in response to each query?

(7) If so, does that also apply if the cumulative effect of the repeated re-utilisation of those insubstantial parts is that a substantial part of the contents of the database is made available to the individual users together?

(8) Is Article 7(5) of the Directive to be interpreted as meaning that, if conduct which has not been approved and which is such that, as a result of the cumulative effect of reutilisation, the whole or a substantial part of the contents of a protected database is made available to the public, the requirements of that provision are satisfied, or must it also be claimed and proved that those acts conflict with the normal exploitation of the database or unreasonably prejudice the legitimate interests of the maker of the database

(9) Is it assumed that the investment of the maker of the database is seriously prejudiced in the event of the aforementioned conduct?

At the time of writing this study, the case is still pending before the ECJ. It will be interesting to see how the Court will respond to these fundamental questions regarding the permissible extraction and re-utilisation of the content of a database by a dedicated search engine. 


\subsection{Exceptions and limitations}

The Dutch legislator literally transposed Article 9 of the Database Directive in Article 5 of the Act as follows:

The lawful user of a database which is made available to the public in whatever manner may not without the authorisation of the producer of the database extract or re-utilise a substantial part of the contents of the database:

a) in the case of extraction for private purposes of the contents of a nonelectronic database;

b) in the case of extraction for the purposes of illustration for teaching or scientific research, as long as the source is indicated and to the extent justified by the non-commercial purpose to be achieved;

c) in the case of extraction or re-utilisation for the purposes of public security or an administrative or judicial procedure.

In addition to these exceptions, the Dutch Database Act contains in Article 8(2) a unique provision, modelled upon Article $15 \mathrm{~b}$ of the Copyright Act. The provision reads:

"The right, referred to in Article 2, paragraph 1 shall not apply to databases for which the public authority is the producer, unless the right is expressly reserved either in general by law, order or resolution or in a particular case as evidenced by a notification in the database itself or when the database is made available to the public."

The main rationale behind this provision is that when transposing the Database Directive into Dutch law, the Dutch legislator did not want to put the makers of a database in a better position than authors of copyright-protected works. In other words, since works that are made available by or on behalf of public authorities are covered by the exception of Article 15b of the Copyright Act, there is no reason not to apply a similar exception to databases produced by public authorities.

\subsubsection{Italy}

\subsubsection{Protection under the Copyright Act}

The main source for copyright in the Italian legal system is to be found in Articles 2575 et seq. of Book V, Title IX, Codice Civile (Civil Code), where it is established that: "Formano oggetto del diritto di autore le opere dell'ingegno di carattere creativo che appartengono alle scienze, alla letteratura, alla musica, alle arti figurative, all'architettura, al teatro e alla cinematografia qualunque ne sia il modo o la forma di espressione."

The following articles of Title $\mathrm{V}$ establish a set of basic principles regarding rules on first authorship and ownership, content of the right, a specific article on 
Forms of legal protection

plans and technical drawings, entitlement to the right, and formalities regarding its transfer. Article 2583 ends the section with a reference to the special law (the Copyright Act ${ }^{194}$ ) for specific rules on the exercise and the duration of the right.

\subsection{The work}

Articles 1 and 2 of the Italian Copyright Act, identify what is protected under copyright law. Under Title I, Paragraph I ("protected works"), Article 1 grants copyright protection to works of ingenuity possessing creative character that belong to literature, music, figurative arts, architecture, theatre and cinematography, regardless of the manner or form of expression. In the second part of Article 1, computer programs and databases, which by reason of the selection or arrangement of their contents constitute the author's own intellectual creation, are also specifically included in the protection offered by copyright.

The following Article 2 offers a non-exhaustive list of works explicitly covered. Such list includes: literary, scientific, educational works in written or oral form; works of sculpture, paintings and figurative arts; works of cinematographic art (excluding mere documentation); photographic works (excluding photographs that do not constitute an original creation); computer programs; and databases defined as collections of works, data, or other independent elements, systematically and methodically organised, and individually accessible by electronic or by other means ${ }^{195}$.

Creativity is not defined by the Act, but it is commonly accepted that a work, in order to possess such creative character, needs to represent somehow the personality of its author (his ingenuity). Courts have interpreted creativity as the particular form or expression given to a work by its author, including in those cases where the basic elements used for such results were commonly known and available, as long as the expression given to them by the author somehow represented his own subjective, creative and personal view ${ }^{196}$.

Derivative works, or rather elaborations of creative character (elaborazioni $d i$ carattere creativo), such as translations in another language, transformations in another artistic or literary form, modifications and additions that constitute a substantial remaking of the original work, adaptations, reductions, and variations that do not constitute an original work, are protected by copyright without prejudice to the right protecting the original work (Article 4). This is to say that a derivative work is a work that is protected by itself, but which also infringes the copyright on the original work, and therefore a specific authorisation (such as a licence) is required.

\footnotetext{
194 See Legge 22 April 1941, n. 633 "Protezione del diritto d'autore e di altri diritti connessi al suo esercizio".

195 See T. Milano, 19.03.2007, in Dir. Ind., 2008, 85.

196 See, for example, Cass. 12 January 2007, n. 581 Foro it., 2007, I, 3167; Cass. 11 August 2004, n. 15496, id., Rep. 2006; Cass. 7 March 2003, n. 3390, id., Rep. 2003.
} 


\subsection{Exclusive rights}

Exclusive rights are listed under paragraph III of the Act. Article 12 opens the section dedicated to the protection of the economic utilisation of the work establishing that the author has the exclusive right to publish the work. Furthermore, the author has the exclusive right to economic exploitation of the work in any form and manner, original or derived, within the limits established by the law.

Articles 13 to 18-bis list the exclusive rights that the statute grants to authors of original works. The first of these rights is the right of reproduction in multiple copies of the work. Copies can be direct or indirect, permanent or temporary, partial or entire, in any manner or form, such as hand-made reproductions, printing, photography or cinematography (Article 13). Also explicitly covered is the right to put an oral work into a written form (Article 14).

The right of communication to the public is dealt with by Article 16, and covers the use of wired or wireless communications, by use of telegraph, telephone, radio and television (satellite and cable transmissions). The right of communication includes the right to make works available to the public in such a way that members of the public may access them from a place and at a time individually chosen by them.

The exclusive right to distribution provides the authors with the right to authorise or prohibit any form of distribution to the public by sale or otherwise (Article 17). The right to translate provides the exclusive possibility for authors to translate or modify their works, to publish the works in collections, and to modify the work in any form (Article 18). Article 18-bis deals with rental and lending rights.

Article 19 closes the section and states that the aforementioned rights are independent of each other and the exercise of one of them does not preclude the exclusive exercise of any other right.

\subsection{Exceptions and limitations}

Exceptions and limitations under the Copyright Act are contained in paragraph V "Exceptions and limitations", although, before the enactment of the Info Directive the paragraph was dedicated to "Free uses". The most relevant exception for the cases covered by this study is certainly represented by Article 70, which is a quite peculiar merger between the exception regarding scientific and educational uses (Article 5(3)(a) Info Directive), and the exception for quotations for criticism or review (Article 5(3)(d) Info Directive). The main consequence of such unnecessary combination is that the exception for scientific and educational uses is subject to the same quantitative limit established for the case of quotations for criticisms or review (the Italian legislator uses the terms "brani o parti di opera"), an effect which is not required by the EU framework. Courts have nonetheless proved to 
be very keen on a literal interpretation of Article 70, stating that only reproductions of parts of a work can be covered by the exception under analysis ${ }^{197}$.

Of some interest is the case of Article $70 \mathrm{sec}$. 1-bis establishing that the publication on the internet for teaching or scientific purposes of low resolution or de-

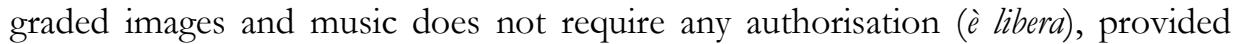
that such publication does not pursue a commercial purpose (scopo di lucro) or any other form of compensation ${ }^{198}$. This provision has never been interpreted by the courts, nor has the legislative decree that should determine the technical specifications regarding the meaning of low resolution images or music been enacted.

\subsubsection{Protection as databases}

Italy has adopted the Database Directive with legislative decree 169 of 6 May 1999199, which amended the Italian Copyright Act. The transposition technique chosen by the Italian legislator is based mostly on the translation of the Directive. Article 1 section 2 and Article 2 section 9 now list databases as protectable subject matter. However, a detailed regulation of databases protection under copyright law is included in new section VII (Arts. 64-quinquies to 64-sexies) under the title "Databases". Sui generis protection of databases is contained in Title II-bis (Articles 102-bis to 102-ter) labelled "Disposition on the maker of a database - Rights and obligations of the user".

\subsection{Requirement for protection}

As mentioned, the transposition of the Directive into national law has followed a strictly literal translation of the former, and no particular observation need to be made in this respect in addition to what already has already been observed in the analysis of the Directive 200 .

\subsection{Rights owner}

The maker (il costitutore) is defined as the person who realises relevant investments in the constitution, verification or presentation of a database. Differently from recital 41 (and from the French implementation), neither the initiative nor the risk parameter are listed, although they might arguably be subsumed in the concept of

\footnotetext{
197 See Corte di Cassazione, 7 March 1997, n. 2089, in Dir. Autore, 1997, 362; App. Milano, 25 January 2002, in Annali it. Dir. Autore, 2002, 801; App. Milano, 21 March 2000, in Annali it. Dir. Autore, 2000, 930; Trib. Milano, 23 January 2003, in Dir. Autore, 2004, 96; Trib. Roma, 13 October 2004, in Annali it. Dir. Autore, 2005, 564; See for references T. Margoni, 'Eccezioni e limitazioni al diritto d'autore in Internet', Giurisprudenza Italiana, 2011, 8-9, August-September, 1959.

198 Introduced by Legge 9 January 2008, n. 2 "Disposizioni concernenti la Societa italiana degli autori ed editori” in Gazzetta Ufficiale n. 21, of 25 January 2008.

199 See Decreto Legislativo 6 May 1999, n. 169 "Attuazione della direttiva 96/9/CE relativa alla tutela giuridica delle banche di dati” in Gazzetta Ufficiale n. 138 of 15 June 1999.

200 See above Chapter 2.3.
} 
investment. In the Dutch act, only the risk factor is explicitly mentioned. Such variety of definitions is probably to be explained with the fact that a definition of the maker of a database is only present in the recitals of the Directive not in the articles, leaving Member States with less guidance on how to implement such provision. The initiative versus factor dichotomy has been analysed by the literature, with different positions emerging 201.

Contrary to other jurisdictions, in Italy case law with regard to SGDR is relatively limited. An important decision, however, for the specific aspect of ownership of the sui generis right is Edizione Cierre v. Poste 202 , where the court (first instance, though an Intellectual Property specialised section) established that a public administration does not qualify for SGDR as the EU and national legislators only speak of companies and firms and a public administration is neither a company nor a firm. Worthwhile is to mention that the tribunal makes a reference in its obiter to the fact that the public administration gathered such data when it was the only (public) monopolistic player in that field, adding an argument in favour of the prohibition of sole sourced databases. Previous decisions at the same level have however assumed that public administrations can be the rights owner of SGDR.

\subsection{Exclusive rights}

The rights granted by the Italian legal framework are based strictly on a literal implementation of the Database Directive and no relevant decisions have been delivered that suggest a different interpretation from the one based on the EU legal framework analysed above ${ }^{203}$.

\subsection{Exceptions and limitations}

Some differences are, however, present for the case of exceptions and limitations. The Italian legislator has opted for an implementation that does not allow a specific exemption for acts of reproduction for private purposes of a non-electronic database, as made possible by Article 6(2)(a) of the Directive.

It must be observed that the Italian legislator in the specific case of Article 6(2)(b) has introduced an additional limitation that should be tested against the EU framework set forth by the Directive for potential incompatibility. In fact, for reasons not completely clear, Article 64-sexies (a) introduces the condition that education or scientific research should not be developed within an enterprise (therefore posing a threat to the use by private educational institutions, a view that potentially conflicts with the interpretation that the commercial requirement for

\footnotetext{
201 See Beunen, note 188 above, p. 151.

202 See Trib. Roma - Sezione IP - ordinanza 5 giugno 2008 - Edizioni Cierre s.r.l. c. Poste.

203 See above Chapter 2.3.
} 
Forms of legal protection

educational cases should follow as per Recital 42 of the Info Directive) ${ }^{204}$. However, an even more serious flaw in the transposition is found in the second part of Article 64-sexies (a): "in the ambit of activities of access and consultation, eventual operations of permanent reproduction of the entirety or of a substantial part of the content on a different media are in any case subject to the authorisation of the right-holder". Since Article 64-sexies (a) applies to copyright-protected databases, and only to the copyright on those databases, as the SGDR is regulated in a different section of the Act, such limitation seems to unduly restrict the possibility to use such databases for didactic and scientific purposes. However, when analysing Title II-bis (the two articles dedicated to the rights and obligations of users in cases of the SGDR), the absence of any exception or limitation to the SGDR as contained in Article 9 of the Directive catches the reader's attention. Therefore, following a systematic interpretation, the Italian legislator has decided to take the chance offered by the EU legislator not to implement any SGDR exception. A different interpretation, one that would try to give sense to the wording of Article 64-sexies, would be one that sees in such article a merger of the exception for didactic and scientific uses both for copyright and for SGDR purposes. The major obstacle to such an interpretation is, as already pointed out, of a systematic nature (Article 64-quinquies and sexies are placed in a section of the Copyright Act that explicitly regulates copyright). In addition, a statutory interpretation argument can be found, as such articles use terms as author of a database and not maker.

An open door for an argument that SGDR exceptions and limitations are actually in force in the Italian legal system could be found in Article 71-decies, which concludes the section dedicated to the exceptions and limitations to copyright. This article stipulates that exceptions and limitations to copyright law extend also to Article 102-bis (but not to 102-ter regulating rights and duties of users), to the extent applicable. Italian copyright law did not know a similar right to the SGDR (therefore limiting the possibility to maintain exceptions to SGDR not listed in Article 9 of the Directive), however such provision seems to permit the application to the SGDR of those limitations present in Italian copyright law that are similar or equivalent to those contained in Article 9 of the Directive, namely that for didactic and scientific purposes. It is not clear, however, why such an inscrutable drafting technique has been chosen to achieve something that is indisputably foreseen by the EU legislator. Only future case law will tell us which one of the proposed interpretations will be held to be correct.

\footnotetext{
204 Recital 42 reads "When applying the exception or limitation for non-commercial educational and scientific research purposes, including distance learning, the non-commercial nature of the activity in question should be determined by that activity as such. The organisational structure and the means of funding of the establishment concerned are not the decisive factors in this respect.".
} 


\subsubsection{France}

\subsubsection{Protection under copyright law}

In France copyright is regulated in the Code de la Propriéte Intellectuelle (Intellectual Property Code, IPC ${ }^{205}$ ) which deals with literary and artistic property as well as with industrial property.

\subsection{The work}

Protected subject matter is any work of the intellect (toutes les oeuvres de l'esprit), regardless of the genre and form of expression, merit or purpose (Article L112-1 IPC). In order to be protected by copyright such works have to meet some level of originality, usually defined as a creative effort carrying the personality of its author, an intellectual contribution of the author, or choices reflecting the author's personality ${ }^{206}$. Article L112-2 offers the customary non-exhaustive list of protectable works. Of particular relevance for our case are:

"les livres, brochures et autres écrits littéraires, artistiques et scientifiques; les conférences;

... Les compositions musicales avec ou sans paroles; ... Les oeuvres cinématographiques;

... Les oeuvres de dessin, de peinture, d'architecture, de sculpture; ... Les oeuvres

graphiques; ... Les oeuvres photographiques; ... Les illustrations, les cartes géographiques. "

Also protected are translations, adaptations, transformations or arrangements, anthologies, collections of works or other data, such as databases, which for the selection or arrangement of the content constitute intellectual creations (Article L112-3).

\subsection{Exclusive rights}

Article L122-1 establishes that the author's right of exploitation includes the right of représentation and the right of reproduction ${ }^{207}$. The former consists in acts such as communication to the public by any means, including public presentation, public transmission, and any other dissemination throughout a telematic network ${ }^{208}$.

\footnotetext{
205 Code de la propriété intellectuelle created by loi n $92-597$ du 1 er juillet 1992, as amended.

206 See, for example, Cass. civ. 12 July 2006, n. 05-17555; Cass. civ. 2 March 1999 n. 97-10179; or Cass. civ. 13 November 2008, n. 06-19021.

207 There are some discussions on the correct translation of "droit de representation". The translation of the IPC available on the official website Legifrance refers to "the right of performance", whereas others refer to "the right to publicly display", see in general A. Lucas and H.-J. Lucas, Traité de la propriété littéraire et artistique, 4th edition, Paris, Lexis-Nexis, 2012.

208 See Article L122-2 IPC.
} 
Forms of legal protection

The right of reproduction consists in the material fixation of the work through any process, such as printing, drawing, photography, and any other mechanical or magnetic recording.

\subsection{Exceptions and limitations}

Exceptions and limitations to copyright are regulated under Article L122-5 IPC. Of particular interest for this study are the exemptions from author's authorisation of quotations justified by the purposes of criticism, education, information or scientific character on condition that the name of the author and the source are cited $^{209}$. Also allowed - under the same general obligation to cite the author and the source - are the "representations" or reproductions of excerpts of works, with the exception, inter alia, of works conceived for pedagogic purposes, for the scope of illustration for teaching and research, but not for recreational activities, as long as the public for which such "representations" or reproductions are intended is mainly composed of pupils, students, teachers or researchers. The article also requires the absence of commercial exploitation in order to benefit from the aforementioned exemption, and sets forth a general obligation of fair compensation for authors.

Necessarily present is the exception regarding temporary and transitory acts of reproduction that are part of a licit use or transmission and do not possess independent economic significance (this is the only mandatory exception contained in the Info Directive) ${ }^{210}$.

\subsubsection{Protection as databases}

France has implemented the Database Directive into the IPC with law n. 98-536 of 1998, which amended parts of the first book of the Code introducing the new subject matter of databases for copyright protection, and creating a new Title IV in Book 3 which deals with the rights of database producers ${ }^{211}$. Regarding the implementation of the copyright protection for databases, the French legislator has generally adhered to the wording of the Directive.

\subsection{Requirement for protection}

Article L112-3 offers standard copyright protection to databases which, for reasons of selection or arrangement of the content, constitute the author's intellectual creation.

\footnotetext{
209 See Article L122-5(3) IPC.

210 See Article L 122-6 IPC.

211 The French legislator has preferred the word "producteur" in the implementation of the Database Directive to the word "fabricant" (= maker) present in the French version of the Directive. The word is usually translated as "database producer" to reflect the difference. See Lucas and Lucas, note 207 above, pp. 951 et seq.
} 
Article L341-1 requires a financial, material or human substantial investment in the constitution, verification or presentation of the database in order to offer sui generis protection to the producer.

In a number of decisions French courts have applied a low threshold for the requirement of substantial investment, although many of the cited decisions predate the 2004 ECJ saga establishing that investments in the creation of the database do not qualify in order to establish SGDR protection ${ }^{212}$.

\subsection{Rights owner}

The producer (le producteur) of the database is the person who takes the initiative and bears the risk of the corresponding investment, in accordance with the Database Directive ${ }^{213}$. The French implementation is closely linked to Recital 41 of the Database Directive and mentions both the initiative as well as the risk factor. As seen, the definition of the producer of a database is probably one of the few aspects whose specific wording tends to vary at the national level.

\subsection{Exclusive rights}

According to Article L342-1, the database producer has the right to prevent the permanent or temporary extraction, understood as a transfer in a different medium, of all or a quantitatively or qualitatively substantial part of the contents of a database by any means and in any form. On the issue of extraction, an interesting ruling should be mentioned. In 2011, the Court of First Instance in Paris ruled that a search engine that selected and indexed pages of a website to provide hyperlinks matching the requests of its users did not extract or reuse parts of the database. ${ }^{214}$ This ruling has not been confirmed or reversed by any higher courts.

The producer can also prevent the making available to the public of all or a substantial part of the database in any form. At the same time, the producer can prevent the repeated and systematic extraction or reuse of insubstantial parts as long as such operations manifestly exceed the normal conditions of use of the database 215 .

\subsection{Exceptions and limitations}

Article L342-3 lists the exceptions and limitations to copyright in databases: extraction or reuse of a non-substantial part of the database by a user who has a lawful access to it (Article L342-3(1)); extraction for private use (Article L342$3(2)$ ); reuse by people with disabilities (Article L342-3(3)); reuse for teaching and

\footnotetext{
212 See Beunen, note 188 above, p. 144. See also TGI Paris 25 April 2003; TGI Strasbourg 22 July 2003.

213 See Article L341-1 IPC.

214 See TGI Paris, 1 February 2011.

215 See TC Paris, 5 February 2010.
} 
research (Article L342-3(4)); extractions and reuse by public libraries, museums and archive services (Article L342-3(5)) ${ }^{216}$.

Some significant differences can be observed in the parts regarding the exceptions and limitations to copyright in databases. First of all the mandatory exceptions present in Article 6(1) of the Directive have been implemented more restrictively than in the Directive. In fact Article L122-5 paragraph 5 of the Code states that the acts necessary for access to the content of an electronic database for the needs and within the limits of the use as foreseen in the contract do not require the author's authorisation. As has been noted, in light of the mandatory nature of Article 6(1) of the Directive the French implementation could be found to be in contrast to EU copyright law for a number of reasons. First of all, by mentioning only electronic databases it should be inferred that such provision is not applicable to non-electronic ones, although the Directive does not make such a distinction, and in fact it should be held that EU database law allows for an exception that applies to both electronic and non-electronic databases. Secondly, the French provision only lists acts necessary for access to an electronic database, while the Directive explicitly mentions all the acts listed in Article 5 that are necessary for access and normal use of the database. It must be recalled that the acts listed in Article 5 include temporary or permanent reproductions, translations, adaptations, arrangements and any other alteration, distribution, communication, display or performance to the public of the original or of any modified, adapted or translated parts. Regarding the exceptions for illustration for teaching and scientific research, the general provision of Article 122-5(e) is applicable to all copyright-protected subject matter and therefore also to databases so protected. The only observation is that the French provision requires fair compensation for such uses, something that the Directive does not mention. As to whether other exceptions and limitations that are traditionally authorised under national law (Article 6(2)(d) of the Directive) are applicable under French law, no specific reference is made in the Code. It seems that an interpretation in line with the general principles of law would admit that pre-existing exceptions that apply to copyright should apply also to databases, as long as those are protected by copyright.

Regarding exceptions to the SGDR, the French legislator took the opportunity to introduce an exception for private purposes for cases of extraction of nonelectronic databases (Article L342-3(2)), and for extraction and re-utilisation for illustration for teaching or scientific research (Article L342-3(4)) although once again requiring fair compensation. The exception for public security or administrative or judicial procedures is to be found in a different part of the Code, which applies generally to all rights covered by that section (copyright, neighbouring rights and the SGDR). The wording of such exceptions consequently reads slightly differently from that contained in the Directive.

216 See Lucas and Lucas, note 207 above, pp. 988 et seq. 
An important observation is the omission by the French legislator in Article L342-3 dealing with the exceptions and limitations to the SGDR of the lawful user and it should therefore be concluded that such exceptions are available to any user.

Finally, France has introduced a new exception to the SGDR on the basis of the implementation of the Info Directive. Such exception applies to legal persons and publicly accessible institutions such as libraries, which are allowed to make extractions and re-utilisation of substantial parts of a database for personal consultation by disabled persons and for non-commercial purposes (Article L342-3(3)). Clearly such exception is not listed in the Directive, and this is one of the criticisms that can be brought against the already mentioned unreasonably limited number of exceptions and limitations to the SGDR under EU law.

Finally, the French implementation of the Directive, unlike the case of copyright exceptions, indicates that contractual provisions in violation of the exception of Article L342-3(1) should be deemed null and void. The departure from the European standard this time is observable in the addition of two steps of the three-step test for the case of the SGDR, something not required by the Directive 217 .

\subsubsection{Poland}

\subsubsection{Protection as a copyright work}

Research data may be subject to copyright (author's right) if it satisfies the criteria of protection specified in the Polish Copyright Act (ustawa z dnia 4 lutego $1994 \mathrm{r}$. o prawie autorskim i prawach pokrewnych, Dz. U. 2006 r. Nr 90, poz. 631, consolidated version, subsequently amended - PrAut).

\subsection{The copyright work}

Article 1.1 PrAut defines the copyright work as any result of creative activity having individual character, expressed in any form, regardless of its value, purpose, or manner of expression.

\subsection{Kinds of work}

Article 1.2 PrAut contains a non-exhaustive list of works. The list includes works expressed using words, mathematical symbols or graphical signs (including computer programs); photographs; industrial designs; works of architecture; musical works; audiovisual works; etc.

\footnotetext{
217 See Article L342-3 last sentence: "Les exceptions énumérées par le présent article ne peuvent porter atteinte à l'exploitation normale de la base de données ni causer un préjudice injustifié aux intérêts légitimes du producteur de la base".
} 
There is a whole set of special provisions regarding computer programs, and a separate set regarding audiovisual works. There are also some special provisions referring to e.g. works of architecture and photographs.

Article 4 PrAut contains a list of works explicitly excluded from copyright protection. These are: Acts of law and official drafts of such Acts; government documents, materials, signs and symbols; published patent and other industrial property specifications; simple press information.

\subsection{Work of authorship}

The fact that the work belongs to categories mentioned in Article 1.2 PrAut does not by itself imply protection. Conditions of protection are mentioned in Article 1.1 PrAut (the definition of work of copyright). Also Article $1.2^{\wedge} 1$ may be of interest, since it confirms that the protection applies only to forms of expression and not to the underlying ideas, procedures, methods, principles of operation or mathematical concepts.

The requirements for protection included in Article 1.1 can be restated in the following way:

A work has to be made by a natural person, and reflect the creator's individuality. The personality requirement excludes authorship of computers, animals, or legal persons. Individuality (creativity) is often measured by analysing whether a different person would make a similar contribution in the same circumstances, although this should not be the only criterion taken into consideration.

There is no requirement of fixation in PrAut, but the work has to be expressed in some form noticeable by someone other than the creator.

The work has to be a result of creative activity, which basically excludes ideas as well as results determined by circumstances external to the author. The level of creativity required is not high; it suffices that the work includes just a minimal level of creativity. Hence, copyright protection is relevant mostly with regard to scientific works such as articles, books and other publications comprising at least some arrangement or analysis of data. Data itself is not copyrightprotectable, but a dataset may benefit from protection if there is at least minimum creativity in the collection or arrangement of the data.

\subsection{Authorship and ownership}

Although only a natural person may become a creator of a copyrighted work, such a person is not always the (only) beneficiary of protection. PrAut specifies some cases where economic rights subsist in a person other than the creator (collective works, computer programs). Otherwise, both moral and economic rights belong initially to the creator (or jointly to creators), but economic rights might subsequently be transferred to another person. In the case of works made in the course of employment, they are transferred to the employer upon receipt of the work, 
pursuant to Article 12 PrAut. The exact scope of the transfer depends on the employment contract, but it seems such contracts are not subject to general strict rules requiring, for example, specification of all fields of endeavour in a contract related to copyright subject matter.

In case of scientific works made by employees of scientific institutions, the employer obtains only the first publication right (subject to remuneration) - Article 14 PrAut. Another exception to the Article 12 rule is computer programs - if a computer program is made by an employee in the course of employment, all rights to the program subsist initially in the employer.

Moral rights are non-transferable, but it is possible to contractually undertake not to exercise them.

The holder of economic rights may license them for use instead of transferring them. Licences are contracts, and may be exclusive or non-exclusive.

Both contracts that transfer copyrights and licences are subject to certain rules of PrAut. One of the most important rules is Article 41.2, which requires that fields of endeavour (put simply, different forms of use) are specified (enumerated). The contract covers only such fields that are enumerated in it. There are also other rules intended to protect individual authors against users, the latter traditionally perceived as having a stronger position in negotiations.

\subsection{Exclusive rights}

According to Article 17 PrAut, economic rights are exclusive rights to use and dispose of the work in all fields of endeavour, and to obtain remuneration for the use of the work. Article 50 contains an example list of fields of endeavour, grouped into uses involving reproduction, distribution (of tangible copies, such as sale, donation, lease or rental), and communication to the public. The distribution right in Poland is exhausted by authorised distribution of original or copies of the work in the territory of the EEA, except for lease and rental of such original or copies.

The right of communication to the public involves all forms of dissemination that do not involve tangible media. These include: performance, presentation, screening, playing, broadcasting, retransmitting, as well as making the work available so that anyone may access it at a time and in a place chosen by them (such as when using the internet).

\subsection{Right of adaptation}

Similar to the German regulation, making adaptations does not constitute copyright infringement. Only using a derivative work requires permission of the copyright holder of the original (and of the copyright holder of the derivative) work. There is no definition of a derivative work, but it is generally agreed that it must be a result of a creative transformation of copyright-protected elements of an original work. Inspirations are not considered derivative works. 


\subsection{Limitations}

It is not an infringement of copyright to use ideas and facts underlying the creative expression of the work. The use of the expression, in whole or in part, may be possible without the consent of the copyright holder if it falls under one of the limitations and exceptions specified in section 3 of PrAut. These include personal use, quotation, use for purposes of scientific research and teaching, making available in libraries, archives and schools (including digital on-site terminals) and other exceptions.

It is generally accepted that these limitations do not result in any right of users, but rather they can be used as a legal defence against infringement claims. It is often submitted that these exceptions should be narrowly interpreted. Undoubtedly, apart from vague terms of individual provisions, they are also subject to the three-step test, which has been copied to PrAut in Article 35.

\subsubsection{Protection as databases}

\subsection{Copyright protection}

It is possible to obtain copyright protection for collections of various elements (the elements themselves do not have to be protected by copyright) if there is a creative activity involved in the selection or arrangement of the elements. Such collections might include scientific databases, for example if the criteria for selection or arrangement of the data were not determined by external circumstances. Given the fact that such criteria are often predetermined and the data itself represents mere facts or ideas, copyright protection for scientific databases should be regarded as an exception, but may not be definitely excluded.

Copyright-protected databases are subject to a more narrow personal use exception. It is possible to use them only for personal scientific use not related to any commercial gain. Such databases may not be made available by libraries, archives and schools without authorisation.

Consent of the copyright holder is necessary for the mere creation of an adaptation of a copyright-protected database, not just for the use of such an adaptation as is the case with other works.

\subsection{Sui generis right}

If a copyright-protected database additionally satisfies criteria for sui generis protection, it benefits from two protection regimes. If there is no creativity involved, the sui generis protection might still apply. This regime is implemented in a separate Act (ustawa z dnia 27 lipca 2001 r. o ochronie baz danych, Dz.U. z 2001 r., nr 128, poz. 1402 as amended - Ubd). 


\subsection{Requirements for protection}

The database is protected by the sui generis right if its contents have been systematically or methodically arranged, and are individually accessible. The arrangement, verification or presentation of the database must have required a substantial investment. If there was no investment, the protection does not apply.

\subsection{Right owner}

The owner of the database right is the producer, i.e., the one who makes the substantial investment in the creation of the database (a natural person, or any other legal entity).

\subsection{Scope of protection}

The rightholder has two rights: the right to extract data and the right to reuse the data. The rights do not extend to lease without remuneration (Article $3 \mathrm{Ubd}$ ), and they do not extend to insubstantial parts of the database (provided that such use does not interfere with normal use of the database and is not contrary to the reasonable interest of the producer - Article $7.3 \mathrm{Ubd}$ ).

\subsection{Limitations}

The Ubd contains a specific list of limitations to the sui generis right. Article 8 states that it is possible to use a substantial part of a database for personal use (but only of a non-electronic database), for illustration, for teaching or research (if the use is non-commercial), and for purposes of internal safety, court or administrative procedures. These limitations are subject to the three-step test.

\subsection{National differences}

Whereas copyright requirements are now in the process of being harmonised by the case law of the ECJ, the analysis of the rights situation in the EU as well as in the different European countries shows that there are still some notable differences, especially with respect to the SGDR, which is of most importance for the creation and use of the e-infrastructure of OpenAIREplus. This is surprising as this right was introduced by the European Community itself and should be almost completely harmonised.

\subsubsection{The rightholder}

The first important issue refers to the question of who will be the rightholder of the sui generis right. According to Article 7 of the Database Directive, the Member States shall provide for the sui generis right for the maker of the database. According to 
Recital 41 of the Database Directive, the maker of the database is the person who takes the initiative and the risk of investing.

However, it is still unclear how the ownership has to be verified in the case of public funding. It is remarkable that in most of the Member States, there is no regulation of this issue, and furthermore even no discussion about this fundamental question. The Netherlands so far is the only Member State to have explicitly regulated the exercise of the sui generis right by public sector bodies and generally denies a public authority the right to exercise its exclusive database right ${ }^{218}$. On the other hand, there are strong indications (but no explicit answer) from the ECJ which can be interpreted in the way that public bodies are able to become owners of the sui generis right ${ }^{219}$.

This uncertainty is also of relevance for OpenAIREplus, since it has been created as a publicly funded project. The EU as well as the research entities involved bear part of the financial risk for the creation of OpenAIREplus ${ }^{220}$. This could mean that one or all of them have to be considered rightholders of a sui generis right in OpenAIREplus. However, under the Dutch regulation, this would be excluded.

\subsubsection{Exception for scientific research}

Another slightly confusing issue arises if one looks at national implementation of the exceptions to the relevant IP rights of copyright and the sui generis right.

\subsubsection{Copyright}

According to Article 5(3)(a) Info Directive, the Member States may provide for exceptions or limitations to the exclusive rights in the frame of copyright in the case of use for the sole purpose of illustration for teaching or scientific research, as long as the source, including the author's name, is indicated, unless this turns out to be impossible, and to the extent justified by the non-commercial purpose to be achieved $^{221}$.

First it should be noted that these exceptions are optional and the Member States do not have to implement these limitations. However, the result is a situation where Member States still have different rules and regulations in this context.

In Germany, Article 53 UrhG contains the right of copying a work for personal use or one's own scientific purposes. A use is considered to be private if it belongs to the domestic sphere or the circle of family and friends ${ }^{222}$; a scientific use

\footnotetext{
218 See above Chapter 2.4.3.2.2.

219 See above Chapter 2.3.5.

220 See above Chapter 2.3.7.

221 Cf. also Article 6(2)(b) Database Directive for copyright-protectable databases.

222 Cf. W. Nordemann, in Fromm/Nordemann (eds), note 133 above, \ 53, para. 6.
} 
is related to a scientific activity ${ }^{223}$. In both cases it is only permitted to make single copies of a work 224 . Pursuant to Article 52a UrhG published small parts of a work, works on a small scale and individual articles from newspapers or magazines may be made publicly available to a specific, defined group of participants for the purpose of non-commercial scientific research. However, it should be noted that the latter provision will no longer be applicable after 31 December 2014225.

In the UK, section 29(1) CDPA 1988 provides that fair dealing with an original work will not constitute an infringement if it is carried out for research with a non-commercial purpose or private study. However, the act contains no definition of which kind of dealing with a work is fair and which is not and it is up to the courts to establish in each case whether a dealing is fair or not.

In Poland, the exception for scientific research according to Article 27 PrAut covers "use" of works, which is a very broad term and potentially covers both reproduction and public communication. At the same time it explicitly mentions that scientific and educational institutions are allowed to reproduce only portions of works for their own ends.

In the Netherlands, the research exception covers reproductions as well as acts of making a work available to the public. However, Dutch law requires equitable remuneration of rightholders. Fair compensation is also required by the French legislation 226 .

In Italy, the exception is regulated together with the exception for quotations for criticism or review 227 .

In addition, Article 5(5) Info Directive states in line with the three-step test that exceptions and limitations shall only be applied in certain special cases which do not conflict with a normal exploitation of the work and do not unreasonably prejudice the legitimate interests of the rightholder. When applying the exception or limitation for non-commercial scientific research purposes, the non-commercial nature of the activity in question should be determined by that activity as such. The organisational structure and the means of funding of the establishment concerned are not decisive factors in this respect 228 .

The provision of such exceptions or limitations by Member States should, in particular, duly reflect the increased economic impact that such exceptions or limitations may have in the context of the new electronic environment. Therefore, the scope of certain exceptions or limitations may have to be even more limited

\footnotetext{
223 "Scientific" means an activity that is taught at universities. Cf. ibid., $\ 53$, para. 19; with a broader definition Dreier, in Dreier/Schulze (eds), note 135 above, $\int 53$, para. 23.

224 This means no more than seven copies, cf. BGH, GRUR 1978, 474 - Vervielfältigungsstücke.

225 Cf. Article 137k UrhG.

226 See above Chapter 2.4.5.1.3.

227 See above Chapter 2.4.4.1.3.

228 Recital 42 Info Directive.
} 
when it comes to certain new uses of copyright works ${ }^{229}$. The ECJ confirmed that the exceptions generally need to be interpreted narrowly ${ }^{230}$.

In the light of the foregoing, the diverse regulations in European countries and the wording of the Info Directive, there are many indications that the scope of the exception for scientific use is rather limited. It seems to be impossible to introduce an e-infrastructure whose reproductions and public communications would completely fall within the scope of the exception for scientific use in every European country.

\subsubsection{Sui generis database right}

According to Article 9(b) Database Directive, Member States may stipulate that lawful users of a database that is made available to the public in whatever manner may, without the authorisation of its maker, extract or re-utilise a substantial part of its contents in the case of extraction for the purposes of scientific research, as long as the source is indicated and to the extent justified by the non-commercial purpose to be achieved. Such operations must not prejudice the exclusive rights of the maker to exploit the database and their purpose must not be commercial ${ }^{231}$.

The exceptions mentioned in Article 9 Database Directive are not mandatory, which means that the regulations in the different Member States are not fully harmonised.

In Germany, Article 87c (1) Nr. 2 UrhG states that the copying of a substantial part of a database is possible for one's own private or scientific use. It should be noted that just the copying of data is possible and not re-utilisation. Hence, making a substantial part of a database available to the public (for example in information networks like the internet), even for scientific use, is not permitted ${ }^{232}$.

In the UK, according to regulation 20 Database Regulations 1997, the database right in a database that has been made available to the public is not infringed by fair dealing with a substantial part of its contents if that part is extracted from the database by a person who is a lawful user of the database, it is extracted for the purpose of illustration for teaching or research and not for any commercial purpose, and the source is indicated. This exception, too, only allows extraction and not re-utilisation of substantial parts of a database.

The French provision in case of reuse of substantial parts of databases for research purposes seems to require fair compensation for such use ${ }^{233}$.

In Poland, the research exception is subject to the three-step test $\mathrm{t}^{234}$.

\footnotetext{
229 Recital 44 Info Directive.

230 ECJ Case C-403/08, C-429/08, Football Association Premier League Ltd v QC Leisure et al, [2011]

EuZW 2012, 466, para. 162.

231 Recital 50 Database Directive.

232 Thum, in Wandtke/Bullinger (eds), note 145 above, \87c, para. 31.

233 See above Chapter 2.4.5.2.4.

234 See above Chapter 2.4.6.2.2.4.
} 
The Netherlands literally transposed Article 9 of the Database Directive into national law ${ }^{235}$.

On the other hand, there are states like Italy, where it is rather unclear how the exception should be interpreted ${ }^{236}$.

Hence, the legal situation in the Member States is divergent and partly confusing. In most cases the scope of the scientific research exception is strictly limited. Moreover, for an infrastructure that cannot take account of national borders the strictest legal rules will be determinative. So it seems impossible to make use of scientific research data in an open and participatory infrastructure such as OpenAIREplus. It is only permitted, if at all, for a single researcher to copy data out of a protected database.

\subsubsection{Linking}

The linking of data is an issue that is also not interpreted consistently all over Europe. There is agreement that linking does not constitute a relevant act of reproduction or extraction according to copyright or the SGDR. However, it is still unclear whether linking can be seen as an act of public communication.

Some national courts have decided, that a hyperlink (even a deep link) referring to the content of an external and freely available website does not infringe the publicly making available right of the rightholder ${ }^{237}$. However, the right is infringed when the hyperlink results in the circumvention of technical protection measures the rightholder has taken to prevent uncontrolled public access ${ }^{238}$, e.g. when he has taken measures to prevent direct access to information without visiting the homepage ${ }^{239}$. This interpretation seems to be in line with Article 3 Info Directive and the broad interpretation of the communication to the public right by the ECJ. It allows linking to information that is freely available on the internet, but restricts it in cases where the rightholder has taken measures to prevent (direct) accessibility.

In most other states, there has not yet been a decision providing clear rules on whether hyperlinking should be seen as public communication.

In Poland, on the other hand, it was held, that deep linking constitutes making available to the public ${ }^{240}$. This decision concerns the personal right of a photographed person, but it analyses the "making available" right defined in copyright

\footnotetext{
235 See above Chapter 2.4.3.2.4.

236 See above Chapter 2.4.4.2.4.

${ }^{237}$ See BGH, GRUR 2003, 958 - Paperboy; OGH (Austrian Supreme Court of Justice), GRUR Int. 2012, 817 - Vorschaubilder/123people.at-Thumbnails.

238 Cf. OGH, GRUR Int. 2012, 817 - Vorschaubilder/123people.at-Thumbnails; BGH, MMR 2011, 47 - Session-ID.

239 BGH, MMR 2011, 47 - Session-ID.

240 Sąd Apelacyjny w Krakowie z dnia 20 lipca 2004r. (I ACa 564/04, TPP 2004/3-4/155).
} 
law. In the Czech Republic it was explicitly held that hyperlinking constitutes a communication to the public within the meaning of copyright ${ }^{241}$.

Hyperlinking being a central feature of the www-communication structure, considerable uncertainties remain as to the legal situation. Even with only one or two countries in the analysis diverging completely from a rule leaning towards avoiding infringement, the situation in the other Member States appears to be far from settled. With European legislation not entirely clear on this point, the actual reference to the ECJ ${ }^{242}$ will hopefully clarify this issue finally.

\subsection{Know how/unfair competition/Patent}

Apart from the rights discussed, information may be subject to protection under schemes of know-how protection or unfair competition. The term "know-how" refers to knowledge and skills in connection with the use of products, procedures or business. It is most common in the context of information that is necessary to utilise a patented invention without being part of the patent protection itself.

In legal terms such know-how is mostly protected by the laws referring to secret or confidential information (trade secret law). This information may be of a technical as well as a business nature. This is still purely national law and also no European scheme of protection exists in this respect. However, an international instrument for the protection of confidential information was established in Article 39 of the TRIPs agreement. While its character as intellectual property is still disputed the protection is mostly rooted in national unfair competition laws.

The general core of this protection is the relationship of confidentiality with respect to a company that uses the information ("undisclosed information"). Pursuant to Article 39 TRIPs the protection is of a relative nature meaning that the protection is limited to the time when the information is undisclosed, and, moreover, obtaining the information with legal means is not prohibited.

The national law of the member states of the WTO incorporates the definition of Article 39(2) TRIPs:

"Natural and legal persons shall have the possibility of preventing information lawfully within their control from being disclosed to, acquired by, or used by others without their consent in a manner contrary to honest commercial practices so long as such information:

(a) is secret in the sense that it is not, as a body or in the precise configuration and assembly of its components, generally known among or readily accessible to persons within the circles that normally deal with the kind of information in question;

(b) has commercial value because it is secret; and

${ }^{241}$ Case 8 Td 34/2012 - liberecký pirát.

${ }^{242}$ ECJ case 466/12, Svensson et al v Retreiver, Reference of 18 October 2012. 
(c) has been subject to reasonable steps under the circumstances, by the person lawfully in control of the information, to keep it secret."

As can be seen from this provision the protection is dependent on different factors to be considered. Even machines or procedures that are used on the market may include secret information as long as this information is not readily accessible with reasonable efforts. For example, in the case of software that is distributed only in object code the secret information contained in the software, which can only be extracted from the human readable source code, may not be regarded as obvious when even the process of reverse engineering the software (reverse compilation) will not result in a version of the source code that reveals the relevant information ${ }^{243}$.

The protection is directed against disclosure, acquaintance and use by third parties. It is further refined by a Footnote to Article 39 TRIPs:

"For the purpose of this provision, "a manner contrary to honest commercial practices" shall mean at least practices such as breach of contract, breach of confidence and inducement to breach, and includes the acquisition of undisclosed information by third parties who knew, or were grossly negligent in failing to know, that such practices were involved in the acquisition."

If a third person receives secret information that has been unlawfully acquired he will be liable with respect to further use of the information only in the case that he has knowledge about this state or should have knowledge (gross negligence). Once the information has become obvious and disclosed no secret protection can be enforced after that in the further chain of usage of the information. This is true even with respect to contractual prohibitions which cannot impose duties of confidentiality with respect to disclosed information. Those provisions would be invalid under theories of contract law and competition law. Only in cases where the information has been unlawfully acquired may non-disclosure duties be imposed under national law ${ }^{244}$. This does not include the case of unintentional disclosure.

It is apparent from the fact that protection is limited to obtaining secret information by unlawful means that the protection of confidential information will not play a major role in the field of research data if this data is made readily available for everyone. However, in a situation where a research study is kept confidential or a document with secret information is somehow linked to other data without being readily accessible, this scheme of protection may play a role. If a person makes efforts to obtain the information with unlawful means or receives

\footnotetext{
${ }^{243}$ See W. Blocher and M. Walter, in M. Walter and S. v. Lewinsky (eds.), European Copyright Law, 2nd edition, Oxford/New York 2010; Computer Program Directive at 5.6.13.

244 See BGH, GRUR 1985, 294 (296) - Füllanlage.
} 
this information while it is still confidential and makes further use of it, he may be held liable under trade secret law. However, such cases will be really exceptional in the field under scrutiny here.

Other concepts of unfair competition law may refer to misappropriation of information and use of it in competition, which exist to different degrees in Europe as well as in the US ${ }^{245}$ However, usually this protection is limited to information that constitutes a product or service in competition. Moreover this protection against free riding would have to be considered as being pre-empted by specialised rules like those existing under the sui generis protection schemes for databases. As far as this concept applies, no unfair competition protection may be invoked in addition. Even if this concept applies it does not provide absolute protection of this information but only the competitive use of a product or service to gain a competitive advantage.

In addition there are common concepts of unfair competition relating to taking or appropriating efforts in products and services that would lead to confusion regarding the source of the product or transfer of goodwill as to the reputation of the product. However, these concepts are usually pre-empted by trademark law rooted in national law as well as the European Community Trademark System. This is a separate form of IP that is not a subject of this study.

A special field for the protection of data as such refers to medical data. Article 39(3) TRIPs provides:

"Members, when requiring, as a condition of approving the marketing of pharmaceutical
or of agricultural chemical products which utilize new chemical entities, the submission of
undisclosed test or other data, the origination of which involves a considerable effort, shall
protect such data against unfair commercial use. In addition, Members shall protect such
data against disclosure, except where necessary to protect the public, or unless steps are
taken to ensure that the data are protected against unfair commercial use."

Some countries follow an approach of exclusive protection of this data for up to ten years after market introduction even in cases where no patent is issued ${ }^{246}$. Most developing countries reject this approach which may not be based on Article

\footnotetext{
245 See, e.g., Sec. 4 No. 9 of the German Act Against Unfair Competition Law ("UWG"); see also A. Wiebe, Know-how-Schutz von Computersoftware, Eine rechtsvergleichende Untersuchung der wettbewerbsrechtlichen Schutzmöglichkeiten in Deutschland und den U.S.A., Munich, Beck, 1993.

246 See T. S. Utomo, 'Pharmaceutical Patent Protection and the Introduction of Generic Drugs in Indonesia in the Post-TRIPS Era', IIC 2011, 759 (769); A. X. Felmeth, 'Secrecy, Monopoly, and Access to Pharmaceuticals in International Trade Law', 45 Harvard Int. L. J. 2 (2004); See also M. Yunko, 'Unterlagenschutz für innovative Arzneimittel in der Ukraine', GRUR Int. 2012, 23 (25).
} 
39(3) ${ }^{247}$. Moreover, many countries have established confidentiality protection with respect to all data contained in the application for approval of marketing of medical products.

Patent law is directed at the protection of technical functionality that is implemented in protected machines or procedures. Hence, if the technical structure of the OpenAIREplus infrastructure is based on patented information, patent law may apply. However, in Europe some kind of technical effect has to be present that is not assumed in pure information processing. While the use and distribution of the protected invention is limited by patent laws, the information on the patented invention as such is freely available through the patent specification, which is just the trade-off that patent law seeks to achieve. Hence, even if scientific information is included or related to patented information this information itself can freely be copied and distributed as long as the protected product or procedure is not used or distributed. Copyright may only subsist in the patent specification. As a result patent law will not play any role in the protection of research data as such.

Hence, as regards the OpenAIREplus infrastructure it has to be ascertained that any functionality that is patent protected is used only if patent licences have been obtained. This will mostly be implemented by the relevant systems software, which may be covered by patents on the featured technical functionality. In addition any copyright subsisting in the software used must be taken into account.

247 W. Bannenberg, http://www.essentialdrugs.org/edrug/archive/200502/msg00043.php (last accessed 06/2013). 



\section{Scope of protection}

\subsection{Specific types of usage}

OpenAIREplus aims to establish an integrated research information space that links research results, namely publications and research data. As an open and participatory infrastructure it encourages authors and contributors to share their research data with other users.

Furthermore, OpenAIREplus exchanges metadata with research information systems, literature and data repositories. Links between various information resources can be claimed by users or inferred by sophisticated data mining algorithms. This results in structured information packages which can be further enriched with citation and reference information, usage statistics and linked to similar publications or research data. Such information can be shared between OpenAIREplus as a generic infrastructure with subject-specific and institutional infrastructures.

Some of the data used within OpenAIREplus may be copyright protected. The copyright protection is especially relevant for scientific papers and journal articles. However, the respective databases of research data are usually not protectable by copyright, but instead are protected by the sui generis database protection right.

The following examination analyses the extent to which the scope of protection as refined by the courts covers access and use of research data as envisioned within OpenAIREplus. The extent to which the most relevant types of usage and enrichment (access, linking, mining, reuse in different contexts and value-added modifications and enhancements) infringe the different forms of protection will be considered. The analysis is based on European law and common rules and national differences will be included if necessary.

\subsubsection{Access}

Within the frame of the OpenAIREplus infrastructure, the relevant research data (e.g. research results, publications, databases of raw data, tables/charts and graphics) will be openly accessible to some groups of people, such as users (registered and anonymous) and administrators (data curators). Furthermore, these groups will be able to copy data out of the database for their scientific use.

\subsubsection{Copyright law}

It is at least possible that some of the research data used within OpenAIREplus comprises copyright protectable works (such as full text articles or longer descriptions in metadata). There are basically three relevant exclusive rights which can be 
infringed by accessing the copyright-protected research data; these are the right of reproduction, the right of distribution and the right of communication to the public.

\subsection{The right of reproduction}

Although the possibility to access data does not necessarily mean that the data is copied, the first exclusive right that may be infringed is the right of reproduction.

\subsection{Legal framework}

An important act of harmonisation to the copyright protection within the European Union is the Info Directive ${ }^{248}$. This Directive contains some regulations concerning the reproduction right. It should define the scope of the acts covered by the reproduction right with regard to the different beneficiaries. Thus a broad definition of these acts is needed to ensure legal certainty within the internal market $^{249}$.

According to Article 2 Info Directive Member States shall provide for the exclusive right to authorise or prohibit direct, temporary or permanent reproduction by any means and in any form, in whole or in part for the respective rightholder ${ }^{250}$.

\subsection{Extent of the right}

According to the European jurisdiction, the reproduction has to have a physical form ${ }^{251}$. The right of reproduction fully applies in the digital environment, in particular to the use of works in digital form; the storage of a protected work in a digital form in an electronic medium constitutes a reproduction ${ }^{252}$.

The OpenAIREplus project aims at the development of an electronic open access infrastructure for scientific information. Within this e-infrastructure deposited articles and data will be openly accessible through the OpenAIRE portal to users and administrators. Thereby, the data is shown on the computer screen and can be electronically copied or printed out.

A reproduction may be found in the processing of the data in the user's computer, on-screen display, electronic copying or a printout. Without doubt, the

248 Directive 2001/29/EC of the European Parliament and of the Council of 22 May 2001 on the harmonisation of certain aspects of copyright and related rights in the information society.

249 Recital 21 Info Directive.

${ }^{250}$ Cf. also Article 7 Directive 2006/115/EC; Article 5 lit. (a) Directive 96/9/EC; Article 4(1) lit. (a) Directive 2009/24/EC.

251 Cf. e.g. for the UK section 17(2) CDPA 1988; for Germany BGH, GRUR 2001, 51, 52 Parfumflakon.

252 Agreed Statement concerning Article 1(4) WCT, in conjunction with Article 9 of the Berne Convention; Agreed Statement concerning Articles 7,11 and 16 WPPT; Recital 15 Info Directive states that the Directive also serves to implement a number of the new international obligations of the WCT and WPPT; cf. also for the UK section 17(2)-(5) CDPA 1988. 
printing out of data is a physical permanent reproduction; this is also the case with electronic copies of data on CDs, DVDs or memory sticks and so on, since the data of the database is here duplicated on a new storage medium.

The right of reproduction implies temporary or permanent reproduction by any means and in any form. Hence, this definition could even imply the on-screen display of data. However, it must be noted that the on-screen view is not a material fixation of a work, but merely a two-dimensional visual display so that it is not a physical reproduction. But obviously a material copy of the data shown on the display must exist. Such a copy may be the fixation of the program in the general memory of the computer, or even the fixation in the working memory of the computer.

Since reproduction also means storing the work in any medium by electronic means, the storing in the general memory of a computer is a reproduction in this sense; the general memory is a physical storage medium for permanent storage just like CDs, DVDs, memory sticks and so on. However, to be displayed, data does not have to be stored in the general memory of the user's computer; generally it is sufficient to load the data into the working memory of the computer to show the data on the screen.

From a technical point of view, the loading of data into the working memory is reproduction too. Nevertheless it had been discussed, very controversially, whether it may also constitute a reproduction within the meaning of copyright law, since it is only temporary. However, today, reproduction includes permanent as well as temporary reproduction ${ }^{253}$. Consequently, it is acknowledged today that the loading of data into the working memory of a computer constitutes a reproduction ${ }^{254}$.

Nevertheless, some computer applications do not load the original data into the working memory of the end user's computer. In the case of Application Service Providing (ASP), the data is processed completely on the computer of the provider and just the results of this processing are transmitted by means of distance communication (such as the internet) and shown on the screen of the user; no processing takes place on the user's computer. In this case, whether an act of reproduction is committed by the end user depends on whether the result that is transmitted to the end user's computer is still a part of the protected work ${ }^{255}$.

The reproduction right includes the copying of a work in whole or in part. Hence it is not necessary for the protected work to be copied completely. Howev$\mathrm{er}$, there is no consistent interpretation of the question of when the copying of a

${ }^{253}$ Cf. Article 2 Info Directive; also Article 7 Directive 2006/115/EC (Rental and Lending Directive); Article 5 lit. (a) Database Directive; Article 4(1) lit. (a) Directive 2009/24/EC (Software Directive).

254 So explicitly BGH, GRUR 2011, 418, 419, para. 17 - UsedSoft; in this respect not objecting, ECJ Case C-128/11, Oracle v UsedSoft, [2012] NJW 2012, 2565.

${ }^{255}$ Cf. N. Dietrich, 'ASP - öffentliche Zugänglichmachung oder unbenannte Nutzungsart?', ZUM 2010, 567 et seq. 
part of a work constitutes an infringement. In Germany, for example, it is necessary for copyright to exist in the copied part for an infringement to be committed ${ }^{256}$; under UK law on the other hand, the section taken does not have to be a copyright work in its own right ${ }^{257}$. Accordingly, it has to be decided on a case-by-case basis whether the copying of a specific part of a work infringes copyright. But it must be noted that even using just a very small part of a work can be sufficient to commit an infringement.

\subsection{Interim assessment}

The right of reproduction is infringed if a reproduction is carried out by a person not authorised to do so by the respective rightholder. A reproduction means any temporary or permanent reproduction either in analogue or digital form. The copying of the whole work is not necessary, even the copying of only parts of a copyright work can infringe the copyright in the work.

The printing out of data, the electronic copying on CDs, DVDs and memory sticks, the fixation of data in the general memory and even the loading of the data into the working memory of the computer are acts of reproduction. The onscreen view alone is not a relevant reproduction. This means that the data provider may commit a relevant act of reproduction when he processes the data in his electronic processing systems and databases. The end user commits a relevant act of reproduction when he prints out data and/or loads protected data into the general or working memory of his computer.

\subsection{The right of distribution}

Another right that may be infringed when copyright-protected works are made accessible is the right of distribution.

\subsection{Legal framework}

The distribution right was harmonised by Article 4 Info Directive. According to the article, Member States shall provide for authors, in respect of the original of their works or of copies thereof, the exclusive right to authorise or prohibit any form of distribution to the public by sale or otherwise.

\subsection{Extent of the right}

The right of distribution in particular is subject to some far-reaching changes. Recently, the ECJ has issued some curious decisions. According to the wording of the Info Directive ${ }^{258}$, the distribution right is a right relating to physical exploita-

\footnotetext{
256 Cf. Dreier, in Dreier/Schulze (eds), note 135 above, $\int 16$, para. 9.

257 MacQueen, Waelde, Laurie and Brown, note 82 above, para. 4.15; see also Ladbroke (Football) Ltd $v$ William Hill (Football) Ltd [1964] 1 WLR 273.

258 And also Article 6 WCT.
} 
tion $^{259}$. This would mean that the work or a copy of it has to be distributed in a tangible form to fall within the scope of the distribution right. However, the ECJ recently decided, that at least in the case of computer programs, a distribution occurs even if the computer program was not sold on a physical data carrier such as a CD or DVD but also if it was transferred intangibly via the internet ${ }^{260}$.

It should be noted that this decision has a direct impact only on the distribution right of computer programs, since the decision was strictly limited to application of the Software Directive, which is regarded as lex specialis to the Info Directive ${ }^{261}$. Hence, the distribution right to other works is still a physical exploitation right and the online transmission not a relevant form of distribution; but how long the different treatment of computer programs and all other works will last has already been called into question ${ }^{262}$.

Another notable decision was issued by the ECJ on 17 April 2008263. In this decision, the ECJ decided that the concept of distribution should be interpreted as a form of right that entails a transfer of ownership ${ }^{264}$. This was quite surprising, since it was common practice in some European countries ${ }^{265}$ that a distribution does not have to aim at the transfer of ownership, but that granting possession over a copy of work is sufficient. Moreover, some European countries arranged the rental and lending right as part of the distribution right ${ }^{266}$; and rental and lending does not transfer the ownership of a work.

In a recent decision the ECJ seems to doubt its own decision and states that in the present case a "distribution to the public" under Article 4(1) of Directive $2001 / 29$ occurs even though only the delivery of copies of works and no transfer of ownership takes place in the country in question ${ }^{267}$. Hence it is probably appropriate to assume that the "distribution to the public" under Article 4(1) Info Directive must aim at granting possession over the copy of the work and transfer of ownership is not always necessary ${ }^{268}$.

\footnotetext{
259 See also recital 28 Info Directive: "Copyright protection under this Directive includes the exclusive right to control distribution of the work incorporated in a tangible article.".

${ }^{260}$ Cf. ECJ Case C-128/11, Oracle v UsedSoft, [2012] NJW 2012, 2565.

261 Ibid., para. 56.

262 Cf. M. Stieper, 'Comment on ECJ Case C-128/11 - UsedSoft', ZUM 2012, 668, 670; J. Schneider and G. Spindler, 'Der Kampf um die gebrauchte Software - Revolution im Urheberrecht?', CR 2012, 489, 497.

263 ECJ Case C-456/06, Peek \& Cloppenburg KG v Cassina SpA, [2008] GRUR 2008, 604.

${ }^{264}$ ECJ Case C-456/06, Peek \& Cloppenburg KG v Cassina SpA, [2008] GRUR 2008, 604, 605, para. 33.

265 E.g. Germany and Austria.

266 E.g. Spain and Germany.

${ }^{267}$ Cf. ECJ Case C-5/11, (Donner), [2012] GRUR Int. 2012, 766, 768, para. 30.

${ }^{268}$ Cf. Dietrich, note 148 above.
} 


\subsection{Interim assessment}

Within OpenAIREplus, the users will be able to access the data. The users will not obtain physical possession over a copy of the data. As long as the data is not given to the users on material storage media, the right of distribution will not be infringed.

\subsection{The right of communication to the public}

Probably the most important right in relation to the accessibility of data is the right of communication to the public.

\subsection{Legal framework}

The right of communication to the public was harmonised by Article 3 Info Directive $^{269}$. According to this regulation, Member States shall provide authors with the exclusive right to authorise or prohibit any communication to the public of their works, by wire or wireless means, including the making available to the public of their works in such a way that members of the public may access them from a place and at a time individually chosen by them.

This right should be construed in a broad sense covering all communication to the public not present at the place where the communication originates. This right should cover any such transmission or re-transmission of a work to the public by wire or wireless means, including broadcasting 270 .

\subsection{Extent of the right}

The right of communication to the public is the right to use and exploit a copyright work in non-physical forms. Part of the public communication right is the making available to the public which means interactive on-demand transmissions $^{271}$.

The ECJ held that the term "public" within the meaning of Article 3(1) Info Directive refers to an indeterminate number of potential recipients, and, in addition, implies a fairly large number of persons ${ }^{272}$. In that connection, not only is it relevant to know how many persons have access to the same work at the same time but it is also necessary to know how many of them have access to it in succession $^{273}$. Furthermore, the public who are the subject of the communication are both targeted by the user and receptive, in one way or another, to that communi-

\footnotetext{
${ }^{269}$ Cf. also Article 8 WCT; Article 10 WPPT; Article 8 Directive 2006/115/EC (Rental and Lending Directive).

270 Recital 23 Info-Directive.

271 Recital 25 Info Directive.

272 ECJ Case C-135/10, Società Consortile Fonografici v Marco Del Corso, (SCF), [2012] GRUR 2012, 593, 596, para. 84; Case C-162/10, Phonographic Performance Ltd. v Ireland (PPI), [2012] GRUR 2012, 597, 598, para. 33.

273 Ibid. (SCF), para. 87; (PPI), para. 35.
} 
cation, and not merely "caught" by chance 274 . This means that the public communication right is applicable when a communication or making available is addressed to an indeterminate group of recipients who have access to the work, but not necessarily at the same time.

For a public communication or making publicly available to occur it is not necessary to transmit the respective copyright work to the recipient. It is sufficient if the recipient can access the work (e.g. see a copyright-protected film on TV or online). It follows that, for example, television broadcasting of a work is a communication to the public which its author has the exclusive right to authorise or prohibit $^{275}$.

However, the most relevant form of making publicly available is the publishing of data in information networks (for example, but not only, the internet), e.g. placing a work on a website or facilitating its downloading from a website. The consent of the right owner is always required when his work is to be used in information networks.

\subsection{Interim assessment}

Within the OpenAIREplus e-infrastructure, the research data will be made accessible over network connections such as the internet to a large number of different users. The users will not be obliged to access the data at the same time, but will be able to access them whenever they want.

The right of communication to the public, as well as the right of making available to the public as part of it, are generally applicable to these acts. This means that the consent of the respective rightholder of every copyright-protected piece of data is generally required if the data will be accessible to the users of the e-infrastructure of the OpenAIREplus project. The OpenAIREplus e-infrastructure would infringe the public communication right if it made copyright-protected data accessible to its users without consent of the rightholder(s).

\subsection{Exceptions to the rights}

The Info Directive provides for an exhaustive enumeration of exceptions and limitations to the reproduction right and the right of communication to the pub$\mathrm{lic}^{276}$. Interesting in our context may be the exception for temporary reproduction and the exception for scientific purposes.

\footnotetext{
274 Ibid. (SCF), para. 91; (PPI), para. 37.

275 ECJ Case C-393/09, BS A v Kultusministerium, [2010] GRUR 2011, 220, 223, para. 55.

276 Recital 32 Info Directive.
} 


\subsection{Temporary reproduction}

According to Article 5(1) Info Directive, temporary acts of reproduction that are transient or incidental and an integral and essential part of a technological process and whose sole purpose is to enable (a) a transmission in a network between third parties by an intermediary, or (b) a lawful use of a work or other subject matter to be made, and which have no independent economic significance, shall be exempted from the reproduction right.

Reproductions can be carried out without the consent of the author, as far as they fall within the scope of this exception. Therefore, as a first criterion, the reproductions have to be temporary. A relevant temporary reproduction that may occur during the use of the OpenAIREplus infrastructure is constituted by the loading of data into the working memory of computers. To fall within the scope of the temporary reproduction exception, the purpose of this temporary reproduction must be to enable a transmission in a network between third parties or a lawful use of a work.

In the case of OpenAIREplus, the purpose of the reproduction occurring during the use of the OpenAIREplus infrastructure is not to enable a transmission between third parties ${ }^{277}$, but to use the information included in the infrastructure. The second alternative of Article 5(1) Info Directive privileges the lawful use of a work. A use should be considered lawful where it is authorised by the rightholder or not restricted by law ${ }^{278}$. This requires the authorisation of the rightholder or another legal basis for the use. Thus whether the exception for temporary reproduction will be triggered depends on whether there is a legal basis for the temporary reproduction. Such a legal basis could be, for example, the applicability of another exception to copyright. But a lawful use would also be the accessing of an openly available website. If a rightholder puts information openly available for everyone on the internet, he implicitly authorises internet users to access the website at the same time.

\subsection{Scientific purposes}

In addition to the exception for temporary reproduction, the Info Directive gives Member States the opportunity to provide for exceptions or limitations to the reproduction right and the public communication right for scientific purposes.

According to Article 5(3)(a) Info Directive, the Member States may provide for exceptions or limitations to these rights in the case of use for the sole purpose of illustration for teaching or scientific research, as long as the source, including the author's name, is indicated, unless this turns out to be impossible and to the extent justified by the non-commercial purpose to be achieved ${ }^{279}$.

\footnotetext{
277 This would be the case when a telecommunications company transmits data from one person to another; cf. also Recital 33 Info Directive.

278 Recital 33 Info Directive.

${ }^{279}$ Cf. also Article 6(2)(b) Database Directive for copyright-protectable databases.
} 
However, the exceptions of Article 5 Info Directive are not mandatory and accordingly there are diverse regulations in European countries in place. Furthermore, the Info Directive has a rather strict wording, which limits the scope of the exception for scientific research. Both together make it virtually impossible to introduce an e-infrastructure whose reproductions and public communications would completely fall within the scope of the exception for scientific use in every European country ${ }^{280}$.

\subsubsection{Sui generis protection as database}

A very important kind of research data relate to scientific databases. Scientific databases can contain almost every kind of data, journal articles or abstracts, metadata, raw research data etc.

\subsection{Legal framework}

The database protection was harmonised within the EU in 1996 by the Database Directive. This Directive harmonised the copyright protection of databases and additionally introduced the sui generis database right. The term "database" should be understood to include literary, artistic, musical or other collections of works or collections of other material such as texts, sound, images, numbers, facts and data 281 .

\subsection{Copyright protection}

Article 3(1) Database Directive states that databases which, by reason of the selection or arrangement of their contents, constitute the author's own intellectual creation shall be protected as such by copyright ${ }^{282}$. No other criteria shall be applied to determine their eligibility for that protection; in particular no aesthetic or qualitative criteria should be applied ${ }^{283}$.

The requirements for copyright protection of databases are the same as for other work categories 284 . The selection or arrangement of the data must involve enough of the author's individual creativity to gain copyright protection.

The limitations on the relevant exclusive rights of the rightholder are generally the same as for other works. Those regulations have already been explained above $^{285}$.

\footnotetext{
280 See above Chapter 2.5.2.1.

281 Recital 17 Database Directive.

282 Cf. also Recital 15 Database Directive.

283 Recital 16 Database Directive.

284 Only the UK requires a slightly higher level of originality than for other works, cf. MacQueen, Waelde, Laurie and Brown, note 82 above, p. 280.

285 See above Chapter 3.1.1.1.
} 


\subsection{Sui generis protection}

The Database Directive also introduced a sui generis database protection right.

According to Article 7(1) Database Directive, Member States shall provide for a right for the maker of a database to prevent extraction and/or re-utilisation of the whole or of a substantial part, evaluated qualitatively and/or quantitatively, of the contents of that database.

Article 7(2) Database Directive states that "extraction" shall mean the permanent or temporary transfer of all or a substantial part of the contents of a database to another medium by any means or in any form; "re-utilisation" shall mean any form of making available to the public all or a substantial part of the contents of a database.

\subsection{Extent of the right}

Extraction and re-utilisation are the exclusive rights of the rightholder of the sui generis right. These exclusive rights are limited to the extent that the whole or a substantial part of the database is used. This is because in general, the exclusive rights of the right owner are not affected by the use of insubstantial parts of the database. Thus according to the ECJ, protection does not cover consultation of a published database 286 ; if the maker himself makes the contents of his database or a part of it accessible to the public, his sui generis right does not allow him to prevent third parties from consulting that base ${ }^{287}$.

To commit an infringement, a qualitatively or quantitatively substantial part of the database has to be extracted. Whether a part is substantial or not is decided on a case-by-case basis. The expression "substantial part, evaluated quantitatively", of the contents of a protected database refers to the volume of data extracted from the database and/or re-utilised, and must be assessed in relation to the volume of the contents of the whole of that database ${ }^{288}$.

The expression "substantial part, evaluated qualitatively" of the contents of a database refers to the scale of the investment in the obtaining, verification or presentation of the contents of the subject of the act of extraction and/or reutilisation, regardless of whether that subject represents a quantitatively substantial part of the general contents of the protected database. A quantitatively negligible part of the contents of a database may in fact represent, in terms of obtaining, verification or presentation, significant human, technical or financial invest-

\footnotetext{
286 ECJ Case C-203/02, British Horseracing Board Ltd v William Hill Organization Ltd (BHB), [2004] 2005 ECDR 1, 1, para. 54.

287 Ibid., para. 55.

288 Ibid., para. 70; likewise ECJ Case C-545/07, Apis-Hristovich v Lakorda (Apis), [2009] GRUR Int. 2009, 501, para. 59.
} 
ment ${ }^{289}$. Any part which does not fulfil the definition of a substantial part, evaluated both quantitatively and qualitatively, falls within the definition of an insubstantial part of the contents of a database ${ }^{290}$.

According to EU law, the exclusive rights of the right owner are not affected by the use of insubstantial parts of a database. Nevertheless, Article 7(5) Database Directive contains the provision that the exclusive rights do apply, if nonsubstantial parts of a database are repeatedly and systematically extracted or re-utilised in a way that is contrary to a normal utilisation of the database. This regulation aims at preventing the systematic extraction of many insubstantial parts in order to rearrange them and get a substantial part as the final result.

As one can see, the ECJ gives guidance to national courts on the interpretation of EU law, but it is up to the national courts to decide whether an infringement is committed in a particular case ${ }^{291}$.

In quantitative terms, the BGH in Germany, for example, has held the extraction of $75 \%$ of the data to be a substantial part ${ }^{292}$ and the extraction of $10 \%$ not to be substantial ${ }^{293}$. Interestingly, there are no decisions found in the other European states that are evaluated within this legal study (the UK, the Netherlands, Italy, Poland or France), which give a more precise definition of a quantitative or qualitative substantial part of a database. It seems that most of the states rely on the vague definition of the ECJ without further refinement.

\subsection{Exceptions to the right}

Article 9 Database Directive contains a limited number of exceptions to the sui generis right the Member States can provide for. In our context, the exception for scientific research may be of interest.

According to Article 9(a) Database Directive, Member States may stipulate that lawful users of a database which is made available to the public in whatever manner may, without the authorisation of its maker, extract or re-utilise a substantial part of its contents in the case of extraction for the purposes of scientific research, as long as the source is indicated and to the extent justified by the non-commercial purpose to be achieved. Such operations must not prejudice the exclusive rights of the maker to exploit the database and their purpose must not be commercial ${ }^{294}$.

\footnotetext{
289 ECJ Case C-203/02, British Horseracing Board Ltd v William Hill Organisation Ltd (BHB), [2004] 2005

ECDR 1, 1, para. 71; likewise ECJ Case C-545/07, Apis-Hristovich v Lakorda (Apis), [2009]

GRUR Int. 2009, 501, para. 66.

290 Ibid. (BHB), para. 73.

291 So, explicit, ECJ Case C-304/07, Directmedia Publishing GmbH v Albert-Ludwigs-Universität Freiburg

(Directmedia), [2008] MMR 2008, 807, para. 59.

292 Cf. BGH, MMR 2010, 41 - Gedichttitelliste III.

${ }^{293}$ Cf. BGH, MMR 2011, 676 - Zweite Zahnarztmeinung II.

${ }^{294}$ Recital 50 Database Directive.
} 
The exceptions mentioned in Article 9 Database Directive are not mandatory, which means that the regulations in the different Member States are not fully harmonised and differ significantly. Moreover in many states, the scientific research exception only allows extraction and not re-utilisation of substantial parts of a database ${ }^{295}$.

\subsection{Interim assessment}

Within the OpenAIREplus infrastructure, metadata of publications and research data will be openly accessible to different kinds of people such as users and administrators on an open access basis. Parts of the research data that are accessible via OpenAIREplus are taken from scientific databases. These databases are generally protected by the sui generis database right.

The consent of the respective rightholder is required as far as quantitatively or qualitatively substantial parts of the data of a database are used within the scope of OpenAIREplus. In many countries of the EU, the extraction, but not the re-utilisation, of substantial parts of a database does fall within the scope of the scientific research exception.

Since the OpenAIREplus e-infrastructure aims at providing a comprehensive database of metadata of publications and related scientific research data as far as possible, it is very likely that substantial parts of other databases will have to be used. Even if the used data of the individual acts of use is not of a substantial nature, there is a strong cumulative effect, since many such acts of use of insubstantial parts are carried out within OpenAIREplus, which added together potentially lead to the use of substantial parts. This would also constitute infringement.

The research data is to be accessible on an open access basis to many users over information networks. In many countries, such a making available does not fall within the scope of the scientific research exception. This leads to the result that it is impossible to create an e-infrastructure that can be made available on an open access basis within Europe without the consent of the respective rightholder of the database right. The OpenAIREplus e-infrastructure would infringe the sui generis right if it copied or made available parts of external sui generis-protected databases.

\footnotetext{
295 See above Chapter 2.5.2.2.
} 


\subsubsection{Linking}

The OpenAIREplus infrastructure aims at supporting the research work of European scientists by creating an open access infrastructure. This e-infrastructure among others involves cross-linking of a very broad spectrum of scientific publications and a selected subset of related datasets.

Web-based applications for linking publications to data through different e infrastructures will be developed. In particular, peer-reviewed literature and associated datasets and collections will be linked to create new kinds of complex publications ("enhanced publications").

\subsubsection{Copyright law}

The linking of various sources might constitute an activity infringing copyright.

\subsection{Right of reproduction}

As mentioned before, the right of reproduction gives the rightholder the exclusive right to reproduce his copyright work in physical forms regardless of whether analogue or digital ${ }^{296}$. It is questionable whether the linking of information constitutes a reproduction. It must be noted that the reproduction right requires a new physical fixation of the work in question. A simple hyperlink in an information network such as the internet does not constitute a new physical fixation, but merely an electronic referral to an already existing copy of the work. Consequently, it was held that the setting of a link is not a relevant reproduction of a work ${ }^{297}$.

\subsection{Right of communication to the public}

Probably of more interest in the context of linking of data is the right of communication to the public, including the making available to the public. The public communication right is applicable when a communication or making available is addressed to an indeterminate group of recipients who have access to the work, but not necessarily at the same time ${ }^{298}$.

According to the ECJ, "communication to the public" must be interpreted broadly. Such an interpretation is moreover essential to achieve the principal objective of the Info Directive, which, as can be seen from its ninth and tenth recit-

\footnotetext{
296 See above Chapter 3.1.1.1.1.1 and 3.1.1.1.1.2.

297 Cf. e.g. BGH, GRUR 2003, 958, 961 - Paperboy; District Court of The Hague, 20 December 2006, (Kunstenares v CU2), IEPT 2006-12-20; Court of Appeal of Den Bosch, 12 January 2010, (C More v MyP2P), IEPT 2010-01-12; District Court of Amsterdam, 12 September 2012 (Sanoma v GeenStijゆ) IEPT 2012-09-12.

298 See above Chapter 3.1.1.1.3.1 and 3.1.1.1.3.2.
} 
als, is to establish a high level of protection of, inter alia, authors, allowing them to obtain an appropriate reward for the use of their works 299 .

Article 3(1) Info Directive states that the right is applicable when members of the public may access the work. On the one hand this means that the members of the public do not actually have to access the work, but that the possibility to do so is sufficient; on the other hand it is questionable whether the right can be infringed by a link to already accessible data.

Some national courts have decided that a hyperlink (even a deep link) to the content of an external freely available website does not infringe on the publicly making available right of the rightholder ${ }^{300}$. However, in most of the Member States there has not yet been a decision clearly ruling whether hyperlinking has to be seen as public communication. In Poland on the other hand, it was held that deep linking indeed constitutes making available to the public ${ }^{301}$. Until the ECJ decides about an actual reference ${ }^{302}$, there will be no legal certainty on this point ${ }^{303}$.

In the framework of OpenAIREplus this means that the answer to the question whether the linking to information is possible without the consent of the respective rightholder still depends on the national case law of the European states.

\subsubsection{Sui generis protection as database}

Most scientific databases are protected by the sui generis right. The sui generis database right protects the rightholder against unauthorised extraction and reutilisation of the whole or a qualitatively or quantitatively substantial part of the database ${ }^{304}$. Thus, according to Article 7(2) Database Directive, "extraction" means the permanent or temporary transfer of all or a substantial part of the contents of a database to another medium and "re-utilisation" means any form of making available to the public all or a substantial part of the contents of a database.

In the case of linking information in an information network, this action may be seen as a transfer of data or making available to the public of the database. But again, this raises the question whether the linking in an information network constitutes a reproduction or a making available.

\footnotetext{
299 ECJ Case C-306/05, SGAE v Rafael Hotels SL, [2006] EuZW 2007, 81, para. 36.

300 So BGH, GRUR 2003, 958 - Paperboy; OGH (Austrian Supreme Court of Justice), GRUR Int. 2012, 817 - Vorschaubilder/123people.at-Thumbnails.

301 Sąd Apelacyjny w Krakowie z dnia 20 lipca 2004r. (I ACa 564/04, TPP 2004/3-4/155); likewise in the Czech Republic, case 8 Td 34/2012 - liberecký pirát.

302 ECJ Case 466/12, Svensson et al v Retreiver, Reference of 18 October 2012.

${ }^{303}$ See above Chapter 2.5.3.

304 See above Chapter 3.1.1.2.1 and 3.1.1.2.2.
} 
Basically, the exclusive rights of the right owner of the sui generis right correspond to the common exploitation rights of a copyright owner ${ }^{305}$. Therefore it is appropriate to assume that the exclusive rights to a sui generis-protected database mean the same as in the case of a copyright work.

Accordingly, the linking to information in an information network cannot be regarded as a reproduction and thus no relevant transfer of data takes place ${ }^{306}$. Whether the publicly making available right of the rightholder is infringed by hyperlinking is still loaded with uncertainty in some European jurisdictions. There are decisions in national case law that at least deep linking of information can constitute a relevant act of publicly making available ${ }^{307}$. The pending reference to the ECJ ${ }^{308}$ will hopefully bring clarity to this point.

\subsubsection{Mining}

One of the main objectives of OpenAIREplus is to create and experiment with enhanced publications. These enhanced publications will merge knowledge from different sources in order to identify similarities and connections between different kinds of research data. A set of unique and functional text mining tools for deriving information from content usage patterns will be created to enable this. The resulting knowledge will be used for automated content classification, in order to support scientists looking for information.

\subsubsection{Copyright law}

In so far as data used for data mining activities is copyright protected, some exclusive rights of the rightholder have to be taken into account.

\subsection{Right of reproduction}

It is decisive which kind of relevant actions are carried out by the text mining tools. The text mining tools read, classify and potentially copy the data. Therefore, where copyright-protected data is extracted from an external source, e.g. an external database, the right of reproduction will be infringed.

As mentioned above, the right of reproduction gives the rightholder the exclusive right to reproduce his copyright work in physical forms regardless of whether analogue or digital; this includes temporary copies, e.g. in the working memory of a computer ${ }^{309}$.

\footnotetext{
${ }^{305}$ Cf. Leistner, note 163 above, p. 308.

${ }^{306}$ Cf. above Chapter 3.1.2.1.1.

307 See above Chapter 3.1.2.1.2.

308 ECJ Case 466/12, Svensson et al v Retreiver, Reference of 18 October 2012.

${ }^{309}$ See above Chapter 3.1.1.1.1.1 and 3.1.1.1.1.2.
} 
Copyright does not protect the contents of a work or the ideas behind it, but just the expression of ideas and the respective manifestation. Therefore, reading a protected work is allowed; none of the exclusive rights prohibits this. As far as copyright-protected data is copied, e.g. in the permanent or working memory of a computer, the right of reproduction is applicable. In so far as the copyright work is just read by a human user, there is no copyright-relevant reproduction.

With respect to the exception for scientific use, it has already been shown that it is virtually impossible to introduce an e-infrastructure whose reproductions would completely fall within the scope of the exception for scientific use in every European country ${ }^{310}$.

\subsection{Adaptation right}

Another right that may be infringed by data mining activities is the right of adaptation. This exclusive right defines whether another person is allowed to use a work in the form of changes and modifications to adapt it into another context.

\subsection{Legal framework}

The European legal framework concerning the adaptation right is slightly confusing. At first it is interesting to note that the Info Directive, as an important act of harmonisation, does not contain any provision concerning this right. Article 12 of the Berne Convention generally states that authors of literary or artistic works shall enjoy the exclusive right of authorising adaptations, arrangements and other alterations of their works. Article 5 Database Directive contains the provision that in respect of the expression of the database which is protectable by copyright, the author of a database shall have the right to carry out or to authorise translation, adaptation, arrangement and any other alteration. Article 4 Software Directive states that the exclusive rights of the rightholder shall include the right to do or to authorise the translation, adaptation, arrangement and any other alteration of a computer program and the reproduction of the results thereof 311 .

Accordingly, there has to be a construction which is compliant with the Berne Convention in the EU Member States, but there is only a clear harmonisation of the adaptation right in the EU in the case of copyright-protectable databases and computer programs, but not for other work categories. Hence it depends on the national legislation whether an adaptation of a work is possible without the consent of the author or not. However, as a few examples show, it seems to be a general rule that at least the exploitation of an adapted work is not allowed without the consent of the author. In Germany, for instance, a copyright work can be adapted without the consent of the author. However, according to Article 23 s. 1 UrhG the exploitation of a modified or adapted work is not allowed without the

\footnotetext{
310 See above Chapter 3.1.1.1.4.2.

311 Cf. also Recital 15 Software Directive.
} 
consent of the author. In the UK, the making of an adaptation or doing of any of the other restricted acts in relation to an adaptation of a literary, dramatic or musical work is a restricted act according to section 21 CDPA 1988. In Poland, there is a general right of adaptation, too. The author of an original work has to authorise use of an adaptation. But making adaptations is allowed (with some exceptions computer programs, databases, collective works).

\subsection{Extent of the right}

In the case of text mining, mining tools are used to classify research data and identify similarities and connections. The analysed data are usually stored in large databases. As far as these databases are copyright protected, according to Article 5 Database Directive, the author of the database has the right to carry out or to authorise translation, adaptation, arrangement and any other alteration.

In so far as the individual elements of the database are protected by copyright, it depends on the national legislation, whether an adaptation is allowed or not. In any case, it is questionable whether an adaptation is carried out when data mining activities take place. Admittedly the term adaptation is not defined on an EU level, but it can be assumed that it involves some kind of modification of a work. In the case of data mining, the original data is not modified, but just read, classified and potentially copied. Hence, it can be assumed that data mining activities in general do not constitute an adaptation.

\subsubsection{Sui generis protection as database}

The sui generis database right protects the rightholder against unauthorised extraction and re-utilisation of the whole or a qualitatively or quantitatively substantial part of the database ${ }^{312}$. The sui generis right is infringed where the underlying database is protected by the sui generis right and a substantial part of it is either transferred to another medium or made available to the public.

Within the sphere of data mining activities, data is not made publicly available but just read, classified and potentially copied. Whether the extraction right is infringed or not depends on what actions are carried out by the text mining tools. If protected data is copied, e.g., in the permanent or working memory of a computer, the right could be infringed.

In respect of the exception for scientific use, the copying of a substantial part of a database by a lawful user could be allowed for the purposes of scientific research $^{313}$. However, such operations must not prejudice the exclusive rights of the maker to exploit the database ${ }^{314}$. Furthermore, the regulations on this in the dif-

\footnotetext{
312 See above Chapter 3.1.1.2.1 and 3.1.1.2.2.

313 Cf. Article 9(a) Database Directive.

314 Recital 50 Database Directive.
} 
ferent Member States are not fully harmonised ${ }^{315}$. However, it seems that in many, if not all, European states, the copying has to be carried out by a person for his own scientific use to fall within the scope of the exception for scientific research.

In the case of data mining activities, the potentially occurring acts of reproduction are carried out by automated text mining tools. They are not carried out by a single person for his own use, but by sophisticated data mining algorithms in order to complete the content of the e-infrastructure itself, which is afterwards used by all its users. This means that it is not the single researcher as a person who is the starting point for a potential reproduction, but OpenAIREplus itself. However, if an infrastructure itself is the initiator, the reproduction does not meet the requirement of a copying which is carried out by a person to fall under the scientific use exception. Hence, the exception for scientific use is not applicable in this case.

\subsubsection{Reuse in different contexts/modifications/enhancements}

OpenAIREplus is designed to support the widespread adoption of a culture of sharing, enabling access, use and reuse of data. The data that is processed and used in the OpenAIREplus infrastructure will be reviewed, complemented and enriched by users, administrators and automatic text mining tools in order to improve its value. This raises the question to what extent the reuse, value-added modification and enhancement of protected data is possible without the permission of the IP rightholder.

\subsubsection{Copyright law}

As far as the used data are copyright protected, one of the following rights could apply.

\subsection{Right of reproduction}

According to Article 2 Info Directive, Member States shall provide for the exclusive right to authorise or prohibit direct, temporary or permanent reproduction by any means and in any form, in whole or in part for the respective rightholder.

As has been shown above ${ }^{316}$, the reproduction right is always applicable when a work or a part of it is copied in a physical form. Whether the reproduction right applies depends on whether a new physical fixation of the data is created. Such a physical form of copying is even given by the loading of data into the working memory of a computer. The reproduction right would be infringed by a person or entity who undertakes the copying without the consent of the rightholder.

\footnotetext{
315 See above Chapter 3.1.1.2.3.

316 See above Chapter 3.1.1.1.1.
} 


\subsection{Public communication right}

The public communication right is applicable when a communication or making available is addressed to an indeterminate group of recipients who have access to the work, but not necessarily at the same time. The most relevant form of making publicly available is the publishing of data in information networks (for example, but not only, the internet) ${ }^{317}$.

Accordingly, a relevant public communication takes place if a work or a part of a work is used in an information network. Within OpenAIREplus, the research data is accessible via the internet on an open access basis and treated, reviewed, complemented and enriched via the internet. This means that there has to be a relevant act of public communication to enable the reuse and modification of the data as envisioned within OpenAIREplus. The OpenAIREplus infrastructure would infringe the public communication right by making external copyrightprotected data available to the public.

\subsection{Right of adaptation}

According to Article 5 Database Directive, the author of a copyright-protected database has the right to carry out or to authorise translation, adaptation, arrangement and any other alteration of the database. This enumeration of different types of modifications of a work shows that a very broad definition of the term adaptation is intended. Where the individual/original elements of the database are protected by copyright, whether or not an adaptation is allowed depends on the national legislation. But in any case it would not be possible to exploit a modified work.

Within the OpenAIREplus infrastructure, the contained data will be reviewed, complemented and enriched to create so-called enhanced publications. Therefore, in particular, peer-reviewed literature and associated datasets and collections will be linked.

A broad definition of an adaptation is intended, but nevertheless, it always means some kind of modification of a work. Hence, the question to ask in examining a potentially relevant act of adaptation is whether there is any modification of the protected work itself. A modification would be, for example, the translation of a text into another language, or a written addition to the text of a paper which changes its expression. As far as can be seen, the aim of OpenAIREplus is not to modify the text of papers, or the content of protected data, tables/charts or graphics, but to create added value through linking peer-reviewed literature to associated datasets and collections of raw data. However, if the relevant sets of data are not modified, but just linked to each other, it is rather questionable whether there is a relevant modification. As long as the work is not rewritten or

317 See above Chapter 3.1.1.1.3.2. 
changed, there will generally be no act of adaptation. In particular, there will be no relevant modification through linking of different kinds of data. One could think that the moral right of integrity is potentially infringed, if the protected work of the author is set into a different context. But since the scientific use of scientific data is intended within OpenAIREplus, this is extremely unlikely.

\subsubsection{Sui generis protection as database}

The sui generis database right is infringed where the used database is protected by the sui generis right and a substantial part of it is either transferred to another medium or made available to the public ${ }^{318}$. Thus it is again a question of whether a substantial part of the database is used or made publicly available. An adaptation right is not explicitly mentioned in the Database Directive, for sui generis-protected databases, but an infringement can be assumed when a substantial part of the protected database is extracted or made publicly available in the course of an adaptation.

Within OpenAIREplus, literature will be linked to associated datasets to create added value. The mere linking of data without duplicating cannot be seen as a copying in the sense of the database right; whether the linking of data is a making available to the public is still not entirely clear ${ }^{319}$. Consequently, the reuse, valueadded modification and enhancement of protected data does not infringe the sui generis right, as long as the data is not copied or made available. Whether linking should be seen as a relevant act will be decided by the ECJ soon.

\subsubsection{Additional thoughts}

In so far as the used data is extracted out of an external database and enhanced in its appearance, it is questionable what this means for the rights situation. For example, if data copied out of a data source is rearranged, supplemented by functions and information and connected to other data in order to create an added value, the data that was originally extracted is not changed in its content, but the added functions and information have the effect that the original data seems to be much more valuable afterwards.

Such an enhancement of the extracted data in a new infrastructure could require substantial human, technical and/or financial efforts and thereby lead to a substantial investment in the creation of a new database, the one which contains the enhanced data. This would mean that the maker of the enhanced database is a potential rightholder of a sui generis database right in the new database. But of course, if the extraction of data of the original database was not already authorised by the rightholder of the database right in such database, the maker of the en-

\footnotetext{
318 See for more details above Chapter 3.1.1.2.1 and 3.1.1.2.2.

319 See above Chapter 3.1.2.2.
} 
hanced database needs the permission of the rightholder of the original database to exploit the new, enhanced database.

Another issue arises when users directly contribute to the creation of the database, e.g. when they enter data into the OpenAIREplus database. There might be a question about co-ownership of the contributing users of the IP rights in the database, since they directly supply data to the database. However, one must note that the ECJ decided that resources used during the stage of creation of data or other materials that are subsequently collected in a database cannot be taken into account in order to assess whether there was substantial investment ${ }^{320}$. This means that a substantial investment in the creation of the database itself is required and not merely in the creation or provision of data. In the case of users entering data into OpenAIREplus, the data is just provided to the infrastructure, but the processing and arrangement of the data is subsequently carried out by OpenAIREplus itself. Therefore there is no investment in the creation of the database, but just the provision of data. In addition to that, the effort of users to enter data into the e-infrastructure is rather low and will not be substantial enough to gain the co-ownership of a database right.

\subsubsection{Results}

At first sight, there are two main IP rights that may be applicable in connection with the use of research data. These are copyright and the database right (often also called the sui generis right). These two rights differ in many details. To obtain copyright protection, generally an intellectual creation (a "work") is required. In contrast to that, the database right only requires a substantial investment in the creation of a database. This means that the requirements for protection are lower; on the other hand, the scope of protection is less broad (e.g. the duration of the database right is shorter).

As scientific databases are intended to be as complete as possible and the arrangement of data is usually standard scientific practice, scientific databases will usually fail to meet the requirement of an intellectual creation and thus very rarely be protected as database works under copyright law. As a result, it can be noted that by far the most important IP right in the field of research data is the sui generis right.

Nevertheless, copyright protection has to be taken into consideration in individual cases, not least because it is possible that even if the database is not copyright protected, individual elements of the content are copyright protectable. This is usually not the case for raw scientific data or metadata, but may be possible for scientific papers, abstracts, tables, charts etc.

320 ECJ Case C-203/02, British Horseracing Board Ltd v William Hill Organisation Ltd, [2004] 2005

ECDR 1, 1, para. 34; cf. also BGH, MMR 2011, 676 - Zweite Zahnarztmeinung II. 


\subsubsection{Copyright}

In so far as copyright-protected data is used within OpenAIREplus, the following exclusive rights of the rightholder can be relevant:

Reproduction: A reproduction means any temporary or permanent reproduction either in analogue or digital form. The copying of the whole work is not necessary, even the copying of only parts of a copyright work can infringe on the copyright in the work. The printing out of data, the electronic copying on CDs, DVDs or memory sticks, the fixation of the program in the general memory and even the loading of the data into the working memory of a computer are acts of reproduction. Merely the on-screen view is not a relevant reproduction. This means that the data provider may commit a relevant act of reproduction when he processes the data in his electronic processing systems and databases. The end user commits a relevant act of reproduction when he prints out data and/or loads data in the general or working memory of his computer.

Distribution: The term "distribution to the public" means granting possession over the copy of the work. As long as the data is not given to the users on material storage media, the right of distribution will not be infringed.

Communication to the public: The public communication right is applicable when a communication or making available is addressed to an indeterminate group of recipients who have access to the work, but not necessarily at the same time. The most relevant form of making publicly available is the publishing of data in information networks (for example, but not only, the internet) - e.g. placing a work on a website or facilitating its downloading from a website. The consent of the right owner is always required when his work is to be used in information networks.

Adaptation: In so far as databases are copyright protected, the author of the database has the right to carry out or to authorise any adaptation of his work. In so far as the individual elements of a database are protected by copyright, whether an adaptation is allowed or not depends on the national legislation. But in any case it would not be possible to exploit a modified work. Adaptation always means some kind of modification of a work.

Although the Info Directive gives the Member States the opportunity to provide for exceptions or limitations to the reproduction right and the public communication right for scientific purposes, it turns out that the scope of the exception for scientific use is rather limited in practice. It is virtually impossible to introduce an e-infrastructure whose reproductions and/or public communications would completely fall within the scope of the exception for scientific use in every European country.

\subsubsection{Sui generis Database right}

In so far as the data that is used within OpenAIREplus is protected by the database right, the exclusive rights of the rightholder are those of extraction and re-utilisation. 
Extraction means the transfer of the whole or a substantial part of the content of a database to another medium, e.g. the copying of data into the general or even the working memory of a computer. Re-utilisation means to make the whole or a substantial part of a database available to the public, e.g. via information networks like the internet.

The Database Directive gives the Member States the opportunity to provide for an exception to the exclusive rights of the rightholder for scientific purposes. However, the regulations on this matter are not fully harmonised in the EU and it seems to be impossible to introduce an e-infrastructure that corresponds to the exception for scientific research in all Member States. 


\subsection{Graphical overview and rights matrix}

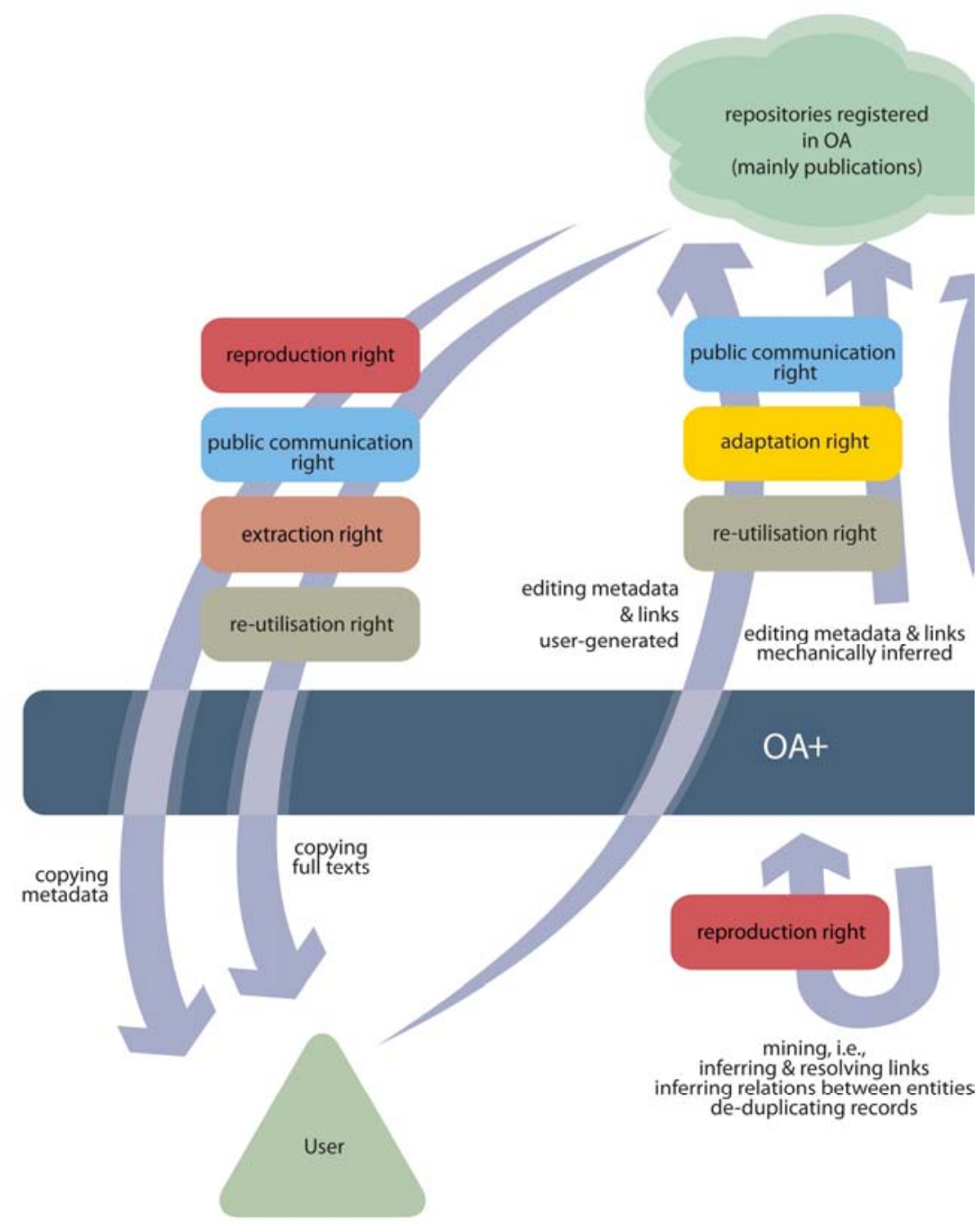

\begin{tabular}{|c|c|c|c|}
\hline & & \multicolumn{2}{|c|}{ copyright } \\
\hline & reproduction right & distribution right & public communication right \\
\hline access & $\begin{array}{l}\text { applicable by copying copyright } \\
\text { subject matter to (by) users from } \\
\text { repositories via OA+ interface }\end{array}$ & $\begin{array}{l}\text { not applicable because OA+ does not } \\
\text { distribute tangible copies (but see } \\
\text { case C-128/11, ZUM 2012, 661 - } \\
\text { UsedSoft) }\end{array}$ & $\begin{array}{l}\text { applicable by making available } \\
\text { copyright subject matter to users from } \\
\text { repositories via OA+ interface }\end{array}$ \\
\hline linking & not applicable by mere linking & not applicable by mere linking & $\begin{array}{l}\text { may be applicable depending on } \\
\text { circumstances (e.g., circumventing } \\
\text { technical protection measures) and } \\
\text { case law of the applicable law }\end{array}$ \\
\hline mining & applicable if involves copying & $\begin{array}{l}\text { not applicable because } \mathrm{OA}+\text { does not } \\
\text { distribute tangible copies }\end{array}$ & $\begin{array}{l}\text { applicable if mined data is made } \\
\text { available, e.g., to OA+ user }\end{array}$ \\
\hline
\end{tabular}

Figure 1: Graphical overview of the rights situation 


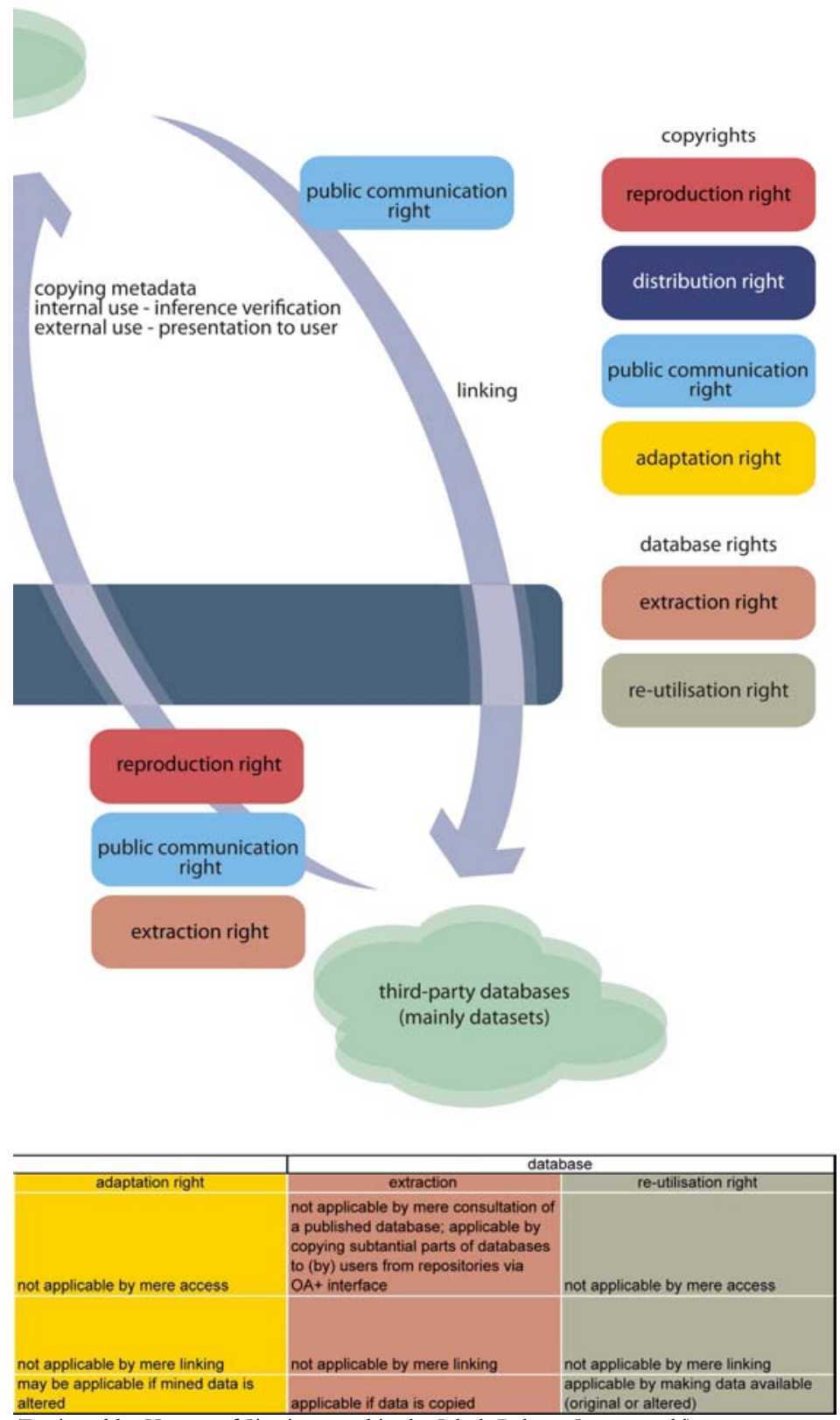

(Designed by Krzysztof Siewicz; graphics by Jakub Rakusa-Suszczewski) 


\section{3 "Legal Prototype" of e-infrastructure}

Some of the data intended to be used in OpenAIREplus is protected by IP rights. Some data may be protected by copyright, but more importantly, most of the scientific databases are protected by the sui generis database right.

Within this part of the study the constraints on access, usage, reuse and enrichment stemming from IP rights relating to the data will be elaborated on in detail, taking into account different views, namely those of the repository, users, author and publisher. The analysis is based on selected scenarios for the usage of research data, e.g. its linking to publications and users contributing to, enriching and curating the data. The scenarios serve as examples of workflows that may potentially be carried out in OpenAIREplus. The questions of which "exclusive rights" of a potential rightholder are relevant in the respective scenario, whether there can be infringement of IP rights, and who would be responsible for such infringements (e.g. researcher, data provider, data processor etc.) will be examined.

\subsubsection{End user scenario A}

Picture a researcher who is a participant in an EC project and reports in OpenAIREplus an Open Access publication (complying with Special Clause 39321) resulting from this EC project. The publication refers to already available primary data that has a DataCite-DOI. The researcher can either enter this DOI or browse datasets with DataCite-DOIs to generate the link between the publication and the data.

\subsubsection{Which types of usage are relevant within the scenario?}

The cross-linking of scientific publications and related datasets is one of the main features of the e-infrastructure of OpenAIREplus. In particular, peer-reviewed literature and associated datasets and collections will be linked to create enhanced publications. Web-based applications will be used for linking publications to data through different e-infrastructures.

End user scenario $A$ is an example of the linking of a publication to primary data. By using the DataCite-DOI of a dataset, the scientist is able to generate a link between the publication and the data. To carry out the linking, the scientist needs to be able to access datasets and technically place the link between the different sources. In order to allow a user to place the link, OpenAIREplus has to resolve the DOI using the DataCite database.

321 See http://ec.europa.eu/research/press/2008/pdf/annex_1_new_clauses.pdf (last accessed 08/2013). 


\subsubsection{Do these types of usage infringe IP rights?}

The type of research data that is dealt with here is primary data. Such primary data will generally not be protected by copyright. But the database that contains the primary data is usually protected by the sui generis right. The sui generis right protects the rightholder against unauthorised extraction and re-utilisation of the whole or a qualitatively or quantitatively substantial part of the database ${ }^{322}$.

\subsection{Substantial part}

The sui generis right is only infringed if a substantial part of the database is used. This is already questionable in end user scenario $A$, since the primary data that is linked is a very small portion of the database. Just one dataset is linked. Although it is decided on a case-by-case basis whether a part of a database is substantial or not, just one set out of many cannot be seen as a substantial part of a database. Even in the case of consulting a database, which is, according to the ECJ, not covered by the sui generis right ${ }^{323}$, it is possible to access more than one dataset.

However, according to Article 7(5) Database Directive, the repeated and systematic extraction and/or re-utilisation of insubstantial parts of the contents of the database, implying acts that conflict with a normal exploitation of that database or which unreasonably prejudice the legitimate interests of the maker of the database, shall not be permitted. The purpose of this regulation is to prevent circumvention of the sui generis right by repeated systematic use of insubstantial parts of the contents of a database, which in the end amounts to the use of a substantial part of those contents.

In end user scenario $A$, the primary data is linked by a researcher just once to the publication. But of course, it is possible that other links to the contents of the database are generated in the context of other publications. However, this linking cannot be called systematic, since the links are set by different researchers in individual cases.

However, the situation may be different if one looks not at the single researcher, but at the OpenAIREplus infrastructure itself. OpenAIREplus is intended to give all researchers the possibility to link data as shown in end user scenario $A$, which means that OpenAIREplus has to resolve all the DOIs of data that researchers want to link to their publications. Every time a dataset is linked, OpenAIREplus has to use the DataCite database to resolve the data's DOIs. The information about the publication which is reported by the researcher to OpenAIREplus becomes part of the content of OpenAIREplus. The linking of publications to underlying primary data is one of the main objectives of the OpenAIREplus project and it is in its vital interest to enable linking between publications and data in or-

\footnotetext{
322 Cf. Article 7 Database Directive.

323 ECJ Case C-203/02, British Horseracing Board Ltd v William Hill Organisation Ltd, [2004] 2005

ECDR 1, 1, para. 54.
} 
der to offer other researchers the possibility to check and further use the data of a publication of interest. Therefore, the resolving actions have to be attributed to OpenAIREplus, as the technical executor and main beneficiary. Because of the potentially large number of scientists using DOIs to link data to their publications, it is possible that the DOI-resolving activities amount to a repeated and systematic use of insubstantial parts of the contents of the DataCite database, which will not be permitted under Article 7(5) Database Directive.

\subsection{Extraction and re-utilisation}

In addition to the requirement of use of a substantial part of the contents, the used part must be either extracted or re-utilised to commit an infringement of the sui generis right. According to Article 7(2) Database Directive "extraction" means the permanent or temporary transfer of all or a substantial part of the contents of a database to another medium and "re-utilisation" means any form of making available to the public all or a substantial part of the contents of a database.

\subsection{Accessing}

In end user scenario $A$, at first the accessing of the database by the scientist may be seen as a relevant action. This would be the case if the data were transferred to another medium or made available to the public.

By accessing the data, the scientist does not make the data available to other people and the linked primary data is not generally transferred to another medium. However, the data is potentially copied into the memory of the scientist's computer, while he accesses the data. Nevertheless, it is highly unlikely that the data so copied would amount to a substantial part of the database, since the scientist merely consults the database and thereby, if at all, copies single elements of the database content into the working memory of his computer.

Admittedly, the EU law provides that the database right also applies if nonsubstantial parts of a database are repeatedly and systematically extracted or re-utilised in a way that is contrary to a normal utilisation of the database. Here the protection aims at preventing the systematic extraction of many insubstantial parts in order to rearrange them and get a substantial part as the final result. But since the scientist in end user scenario $A$ only copies single elements, if any, of the database content into the working memory of his computer and these copies are in fact temporary, there is no risk, that a substantial part of the data is copied by the systematic extraction of many insubstantial parts.

On the other side, the OpenAIREplus e-infrastructure has to resolve all the DOIs of scientists using the service as described in end user scenario $A$ to link data to their publications. This means that OpenAIREplus, that is the institutions which operate OpenAIREplus, has to copy and process in its memory the data of 
the different DOIs. It is possible that these activities could amount to a repeated use of insubstantial parts, which in the end amounts to the use of a substantial part of the contents of the DataCite database, which is not permitted.

\subsection{Linking}

The second possibly infringing action is the linking of the primary data to the publication. A simple hyperlink in an information network does not constitute a new physical fixation, but merely an electronic referral to an already existing copy of the work. Therefore, the work is not copied and thus not extracted.

Regarding the right of re-utilisation, it must be noted that the primary data that is linked in end user scenario $A$ is already accessible on the internet before the linking. With regard to the linking of such data, which is already available online, it was held that a hyperlink (even a deep link) to the content of an external, freely available website does not infringe the publicly making available right of the rightholder ${ }^{324}$. However, there are other decisions which have held that deep linking constitutes making available to the public ${ }^{325}$. Until the ECJ decides about an actual reference ${ }^{326}$, there will be no legal certainty on this point. In the context of our example, this basically means that there is no relevant act of extraction when the primary data is linked. However, regarding the right of re-utilisation, whether the linking is a relevant act depends on the respective national case law.

\subsubsection{Consequences}

As end user scenario $A$ shows, it is still not clear whether users are allowed to generate links to data that is already available on the internet. At least in the case of deep linking, such action would constitute a relevant act of publicly making available in some states. In others, authors who report their scientific papers in OpenAIREplus are generally free to give reference to primary data, which is freely available on the internet. However, the actual reference to the ECJ will will hopefully clarify this issue finally.

During the use of the service described in end user scenario $A$, OpenAIREplus has to process the data of the DOI. The data is thereby copied and thus extracted in the terms of the sui generis right. OpenAIREplus would infringe the sui generis right if it carried out such actions without the permission of the rightholder of the DataCite database.

\footnotetext{
324 So BGH, GRUR 2003, 958 - Paperboy; OGH (Austrian Supreme Court of Justice), GRUR Int. 2012, 817 - Vorschaubilder/123people.at-Thumbnails.

325 So in Poland, Sąd Apelacyjny w Krakowie z dnia 20 lipca 2004r. (I ACa 564/04, TPP 2004/3-

4/155) and the Czech Republic, case 8 Td 34/2012 - liberecký pirát.

326 ECJ Case 466/12, Svensson et al v Retreiver, Reference of 18 October 2012.
} 


\subsubsection{End user scenario B}

Picture a researcher who searches for "mouse genome literature" in OpenAIREplus, finds an interesting document and opens its description page. The page shows the bibliographic metadata of the document, its funding projects and the related research data, in this case a protein, whose name is highlighted as a link. The researcher clicks on this protein name and opens a data description page that contains the OpenAIREplus description of the protein accompanied by the direct link to the open data repository (say, GeneBank) where the protein is originally deposited and the list of documents that are also related with such protein in OpenAIREplus. Note that the researcher has access to functionality for submitting feedbacks to add/remove links between the protein and documents or the document and further research data.

\subsubsection{Which types of usage are relevant within the scenario?}

To create the enhanced publications of OpenAIREplus, researchers will have the ability to edit the content of OpenAIREplus. End user scenario B is an example of a researcher who has the option to check and change the information contained in the OpenAIREplus e-infrastructure. Via the page that shows the bibliographic metadata etc. of the publication, the researcher can access the data description page, which contains the OpenAIREplus description of the protein. The researcher is able to access the linked information, check the correctness of the connection, give feedback and edit links.

\subsubsection{Do these types of usage infringe IP rights?}

The type of research data that is dealt with here is information about a document, such as the bibliographic metadata of the document, its funding projects and the related research data, such as the example protein.

\subsection{Relevant actions}

Such data will generally not be protectable by copyright, since it will lack the requirement of an intellectual creation; but nevertheless, it is at least possible, that some metadata, such as longer descriptions, will meet the requirements for copyright protection. In any case, the database of the data repository, which contains the information about the document or the protein, as well as the database of OpenAIREplus, is potentially protected by the sui generis right.

Intellectual Property rights could especially be infringed when data is copied or made available to the public. Accessing data is generally not a relevant act as long as the data that is accessed is not copied in a material form. In the case of linking, whether linking is a relevant act still depends on the respective national case law ${ }^{327}$.

${ }^{327}$ See for a detailed analysis on this point above Chapter 3.1.2. 
Additionally in end user scenario $B$, a relevant act of copying would take place if the scientist copied metadata out of the repository database or the data description page of OpenAIREplus. In so far as the copied data is not protected by copyright but only the underlying database by the sui generis right, a substantial part of the database content has to be copied to commit an infringement. Alternatively, nonsubstantial parts of a database have to be repeatedly and systematically extracted or re-utilised in a way that is contrary to a normal utilisation of the database.

It is not necessary that the data is copied in electronic form. The transfer of material from a protected database to another database following an on-screen consultation of the first database and an individual assessment of the material contained in that first database is capable of constituting an "extraction" within the meaning of Article 7 Database Directive to the extent that that operation amounts to the transfer of a substantial part of the contents of the protected database, or to transfers of insubstantial parts which, by their repeated or systematic nature, would have resulted in the reconstruction of a substantial part of those contents $^{328}$. At first sight, the ECJ judgement in the Directmedia case potentially carries the risk that a scientist who is consulting a database could accidentally infringe the database right, when he has in his mind information that is contained in a protected database. However, as the ECJ clarifies, an infringement only occurs when the aim of the extraction is the reconstruction of a substantial part of the database content. Such reconstruction is not the aim of scientific research.

Furthermore, it is possible that an act of copying falls within the exception for scientific research. Therefore, the copying has to be carried out by a person for his own scientific use. In the case of end user scenario $B$, the researcher is potentially copying metadata out of the repository database or the data description page of OpenAIREplus. He does so because he searches for "mouse genome literature" for his own research. Such copying would thereby fall within the scope of the scientific research exception.

As a result, accessing is not a relevant act as long as the data that is accessed is not copied in a material form. Whether linking is a relevant act depends on the respective national case law. However, in so far as content of the repository database or the data description page of OpenAIREplus is copied, there could be infringement by the scientist of the IP rights in the repository database, and/or its content and the OpenAIREplus data description page. If such copying is done for the scientist's own research, it would fall within the scope of the scientific research exception.

328 ECJ Case C-304/07, Directmedia Publishing GmbH v Albert-Ludwigs-Universität Freiburg (Directmedia), [2008] MMR 2008, 807. 


\subsection{Alteration}

Another relevant question in end user scenario $B$ is whether the option to edit the information about the document and the protein contained in the OpenAIREplus data description page leads to an infringement of IP rights.

First, the OpenAIREplus database, namely its data description page, is edited. The OpenAIREplus database is protected by the sui generis right. Furthermore, the repository database is protected by the sui generis right too and it cannot be ruled out that at least some of the metadata is copyright protected.

The editing of information may be seen as an adaptation of the original content. But regarding the sui generis right, it must be noted that there is no independent right of adaptation existing in the scope of protection of this right. This means that an adaptation may only be relevant if it leads to a transfer of the contents of a database to another medium or making the contents of a database available to the public.

However, the researcher in end user scenario $B$ does not copy or make available to the public the contents of the database of the repository or OpenAIREplus, at least as long as he does not load a substantial part of the database(s) content or insubstantial parts that result in the reconstruction of a substantial part of those contents into the memory of his computer.

The exception for scientific research would be applicable if the copying were carried out by a person for his own scientific use. In end user scenario $B$, the researcher is editing the information about the document and the protein contained in the OpenAIREplus data description page. This action is not part of his research in the area of mouse genomics. Instead, he is providing the other users of OpenAIREplus with additional information about the protein and related documents. Thus, he is not undertaking these actions for his own research but for the research of other scientists. Such copying would not fall within the scope of the scientific research exception.

Furthermore, he is not able to edit the description of the protein, as it is provided by the data repository (here the gene bank), but only the information that is contained in the OpenAIREplus data description page. Thus, the OpenAIREplus database is edited and not the database of the repository. Whether such alteration is allowed depends on whether it implies the copying of substantial parts of the database or not.

\subsubsection{Consequences}

A data repository (such as the gene bank in the scenario) cannot prevent data made available by it from being accessed, as long as the data is not copied into the memory of external computers, and if such copying is done by a scientist for his own research, it would fall within the scope of the scientific research exception. In accordance with the situation concerning linking, whether it is a relevant act depends on the respective national case law. 
If data is copied out of the database of the repository, there can be infringement of IP rights. However, if a single researcher copies data for his own scientific purpose, the scientific research exception would be applicable.

The users of OpenAIREplus can edit the content of the data description page without infringing the database right of a repository. However, they need the permission of the IP rightholder in OpenAIREplus to copy substantial parts of the OpenAIREplus database content or insubstantial parts that result in the reconstruction of a substantial part of those contents. If the data is copied by individual researchers for their own scientific use, the copying would be allowed by the scientific research exception. This exception is not applicable when a researcher edits the information that is contained in the OpenAIREplus data description page.

Since the option to edit the content of OpenAIREplus is one of the aims of the project it can be assumed that the rightholder of potential IP rights in OpenAIREplus will give his consent to such uses.

\subsubsection{End user scenario C}

Picture a researcher in the field of the social sciences who is performing secondary analysis on a longitudinal survey of employment data, which are provided by a social science data archive. Now, looking at a specific variable, say "age", a recommender service appears on the side of the browser screen showing recent publications that have studied the relation between "age" and "employment". A single click will lead the researcher to the publication.

\subsubsection{Which types of usage are relevant within the scenario?}

End user scenario $C$ is an example of a tool of OpenAIREplus that allows its user to find literature more easily. Once the user is looking for specific information, in this case employment data and the variable age, the tool checks the OpenAIREplus e-infrastructure for publications that are related to these subjects and draws the researcher's attention to recent publications related to the searched subjects (age and employment). Through a link the researcher can directly access these publications. While the tool is used, the OpenAIREplus database is searched for related information and links to external websites, which the researcher can access.

\subsubsection{Do these types of usage infringe IP rights?}

\subsection{The use of the OpenAIREplus database}

The first action of interest is the checking of the OpenAIREplus database for relevant publications by the tool. Since the OpenAIREplus database is protected by the sui generis right, there may be relevant acts of extraction in relation to this 
database. There would be a relevant extraction if data were copied out of the OpenAIREplus database into the memory of the researcher's computer and this data constituted a substantial part of the contents of the OpenAIREplus database or insubstantial parts of the content were repeatedly taken and resulted in the reconstruction of a substantial part of those contents.

It is generally necessary that the data, which is shown on the computer screen of the researcher, is at least loaded into the working memory of his computer. However, in end user scenario $C$, only single elements of the database such as words or links are transferred to the researcher so that this data will not form a substantial part of the database. Furthermore, these single elements of the OpenAIREplus database are only loaded into the working memory of the computer, which means that they are only stored temporarily during the use of the OpenAIREplus service. Thus, there is no risk that the copying of several pieces of information will lead to the systematic extraction of many insubstantial parts, which in the end form a substantial part of the database's content. Furthermore, the ECJ has ruled that protection of the sui generis right through the exclusive rights does not cover consultation of a database ${ }^{329}$. And the use of the recommender service here described can be seen as a mere consultation of the database of OpenAIREplus. Altogether, this means that there is no relevant act of extraction in relation to the OpenAIREplus database.

\subsection{The use of external resources}

Other potentially relevant actions are the accessing of the external documents and the use of the links by the researcher.

In so far as the linked documents are contained in a sui generis-protected database, accessing the data is generally not a relevant act as long as the data that is accessed is not copied in a material form (e.g. in the working memory of a computer); in the case of linking, it still depends on the respective national case law whether linking is a relevant act ${ }^{330}$. In any case, only single documents of external resources are transferred to the researcher in this scenario. These single elements of a database will not form a substantial part of its contents. Furthermore, the accessing of single elements is nothing more than a consultation of the database which is, according to the ECJ, not covered by the sui generis database right ${ }^{331}$.

Additionally, in end user scenario $C$, the researcher is able to follow links that lead him not just to bibliographic metadata of a document, but directly to scientific publications. Scientific papers are usually protected by copyright. This raises the

\footnotetext{
${ }^{329}$ ECJ Case C-203/02, British Horseracing Board Ltd v William Hill Organisation Ltd, [2004] 2005 ECDR 1, 1, para. 54.

330 See for a detailed analysis on this point above Chapter 3.1.2.

${ }^{331}$ ECJ Case C-203/02, British Horseracing Board Ltd v William Hill Organisation Ltd, [2004] 2005 ECDR 1, 1, para. 54.
} 
question whether the click on a link or the linking itself may constitute a copyright infringement.

First it is important to note that copyright does not protect the content of a work or the ideas behind it, but just the expression of ideas and the respective manifestation. Therefore, none of the exclusive rights of the rightholder is infringed by the mere consumption of a protected work. Thus, the mere accessing and reading of a protected article is free. At least this is the case in the analogue copyright environment, e.g. when reading a book. However, in the digital environment, the accessing of a work, e.g. via the internet, generally leads to a new physical reproduction of the work, because a relevant reproduction is even the storing of a protected work in the working memory of a computer ${ }^{332}$, which is generally necessary to access a document online.

Nevertheless, it is possible that these reproductions in the working memory fall within the scope of the temporary reproduction exception. This would especially be the case if the temporary reproduction were to enable a lawful use of a work. Such a lawful use would be e.g. the accessing of an openly available publication, since if an author or publisher makes such a publication openly available for everyone on the internet, at the same time he authorises internet users to access the publication and this implies the reproductions that are therefore necessary. Furthermore, it is questionable whether the linking of a copyright-protected work can infringe the copyright in this work. This may be held to be an infringement of the reproduction right or the publicly making available right.

The right of reproduction gives the rightholder the exclusive right to reproduce his copyrighted work in physical forms regardless of whether analogue or digital ${ }^{333}$. In order to be infringed, the reproduction right requires a new physical fixation of the work in question. A simple hyperlink in an information network such as the internet does not constitute a new physical fixation, but merely an electronic referral to an already existing copy of the work. Consequently, it has been held that the setting of a link is not a relevant reproduction of a work ${ }^{334}$.

Regarding the right of making publicly available, some national courts have decided that a hyperlink (even a deep link) to the content of an external, freely available website does not infringe the publicly making available right of the rightholder ${ }^{335}$. However, the right is infringed when the hyperlink leads to the cir-

\footnotetext{
332 Cf. above, Chapter 3.1.1.1.1.2.

333 See above Chapter 3.1.1.1.1.1 and 3.1.1.1.1.2.

${ }^{334}$ Cf. e.g. BGH, GRUR 2003, 958, 961 - Paperboy; District Court of The Hague, 20 December 2006, (Kunstenares v CU2), IEPT 2006-12-20; Court of Appeal of Den Bosch, 12 January 2010, (C More v MyP2P), IEPT 2010-01-12; District Court of Amsterdam, 12 September 2012, (Sanoma $v$ GeenStijl) IEPT 2012-09-12.

335 So BGH, GRUR 2003, 958 - Paperboy; OGH (Austrian Supreme Court of Justice), GRUR Int. 2012, 817 - Vorschaubilder/123people.at-Thumbnails.
} 
cumvention of technical protection measures the rightholder has taken to prevent uncontrolled public access ${ }^{336}$, e.g. when he has taken measures to prevent direct access to information without visiting the homepage ${ }^{337}$.

However, in most European states, there has not yet been a decision clearly ruling on whether hyperlinking is to be seen as public communication. In Poland ${ }^{338}$ and the Czech Republic ${ }^{339}$ on the other hand it has been held that deep linking constitutes making available to the public. Thus the European legislation is not entirely clear on this point, but in any case, the actual reference to the ECJ340 will finally bring clarity on this point. Until then, whether the linking to information is possible without the consent of the respective rightholder depends on the national case law of the European states.

In this context, it should be noted that generally, the exclusive rights of the right owner of the sui generis right correspond to the common exploitation rights of a copyright owner ${ }^{341}$. Therefore they are interpreted in the same way, which means in particular that the exclusive right of extraction in the context of the database right corresponds to the exclusive right of reproduction of the copyright owner; and the right of re-utilisation to the making publicly available right.

\subsubsection{Consequences}

Admittedly, the mere accessing and reading of a protected article is free. However, the accessing of a work via the internet generally requires a relevant act of reproduction at least in the working memory of the accessing person's computer. Regarding the linking, it is still unclear, whether this constitutes a relevant act of communication to the public.

Repositories cannot prohibit the accessing of their data, as long as it does not lead to a new physical fixation of the work. And even if the data is copied in the working memory of a computer these reproductions will usually fall within the scope of the temporary reproduction exception since the accessing of freely available data via the internet and the reproductions that are therefore necessary are generally lawful uses of the data within the meaning of Article 5(1) Info Directive.

\footnotetext{
336 Cf. OGH, GRUR Int. 2012, 817 - Vorschaubilder/123people.at-Thumbnails; BGH, MMR 2011, 47 - Session-ID.

337 BGH, MMR 2011, 47 - Session-ID.

338 Sąd Apelacyjny w Krakowie z dnia 20 lipca 2004r. (I ACa 564/04, TPP 2004/3-4/155).

${ }^{339}$ Case 8 Td 34/2012 - liberecký pirate.

340 ECJ Case 466/12, Svensson et al v Retreiver, Reference of 18 October 2012.

341 Cf. Leistner, note 163 above, p. 308.
} 


\subsubsection{End user scenario D}

Picture a researcher who has completed a substantial amount of cross-checking and supporting analysis in conjunction with a paper ready for publication, but does not have a repository or publisher willing to accept this supplementary information, which is invaluable to scientific colleagues. This researcher therefore submits the supporting documents and data to the OpenAIREplus repository (for "orphaned" data and publications), and refers to it in the publication, giving subsequent scientists the chance to validate and extend the research more easily.

\subsubsection{Which types of usage are relevant within the scenario?}

Within OpenAIREplus, the OpenAIRE orphan repository will be extended to offer deposition and web publishing for data to authors. End user scenario $D$ is an example of how the orphan repository can be used. The researcher deposits the supplementary information in the OpenAIREplus orphan repository and refers to it in his publication, which is published elsewhere.

From a legal point of view, no relevant acts of use are carried out in relation to external objects of protection. In particular, no external copyright work or sui generis-protected database is used. Only the OpenAIREplus database itself is edited and filled with information.

\subsubsection{Do these types of usage infringe IP rights?}

Since there are no acts of use carried out in relation to external objects of protection, no such IP rights can be infringed. Nevertheless, the sui generis right of the OpenAIREplus database may be infringed by the alteration of, and the addition of content to, this database. But it must be noted that there is no independent right of adaptation existing in the scope of protection of the sui generis right and an adaptation may only be relevant if it leads to the copying of the contents of a database or making the contents available to the public.

In end user scenario $D$, no content of the OpenAIREplus database is copied or made available, which means that there is no infringement of the sui generis right.

\subsubsection{Consequences}

Users can make use of the OpenAIREplus orphan repository as described in end user scenario $D$ without infringing IP rights. If OpenAIREplus wants to prevent an open use of the orphan repository, it has to restrict its use.

\subsubsection{Additional thoughts}

Since in end user scenario D, a user of OpenAIREplus provides direct input to the database in the form of a publication that is stored in it, one could consider the 
question whether this contribution leads to a co-ownership of the user of the sui generis right in the OpenAIREplus database. However, the ECJ has decided that a substantial investment in the creation of a database itself is required to gain protection under the sui generis right; efforts during the stage of creation of data or other materials that are subsequently collected in a database cannot be taken into account in assessing whether there was substantial investment ${ }^{342}$.

In the case of a user uploading supplementary information about one of his publications, he may have gone to the effort of creating the data (the supplementary information) and of uploading it to OpenAIREplus, but there is no direct investment in the creation of the database itself. The processing and arrangement of the data is carried out by OpenAIREplus after its provision. Furthermore, the effort required by the user to upload his data to OpenAIREplus is rather low and will not be of a substantial nature, which is required to gain the co-ownership of a database right.

In any case, it is recommended that the fact that there is no co-ownership of IP rights gained by the uploading of publications into the orphan repository of OpenAIREplus is clarified in its terms and conditions or terms of licensing, to avoid misunderstandings.

\subsubsection{Third-party provider scenario A}

Marine biologists share and manage their data using the D4Science Virtual Research Environment (VRE) toolkit. A researcher is going through some datasets and wants to direct his colleagues to all related publications, a task performed by means of filling in an annotation. The researcher knows the names of the project(s) that work on similar topics and clicks on a VRE query mechanism (directed to the OpenAIREplus direct access APIs) with the named projects and a list of publications is automatically attached to this dataset.

\subsubsection{Which types of usage are relevant within the scenario?}

Third-party provider scenario $A$ shows how OpenAIREplus can be used to improve data used by researchers. The data of the marine biologist is enriched by OpenAIREplus data. A researcher fills in an annotation in the marine biologist's data and therefore extracts data from the OpenAIREplus database, in this case a list of publications related to some projects. On the one side, the marine biologist's data is edited by the researcher. On the other side, a link to the OpenAIREplus e-infrastructure is used and information is taken from the OpenAIREplus database.

342 ECJ Case C-203/02, British Horseracing Board Ltd v William Hill Organisation Ltd, [2004] 2005

ECDR 1, 1, para. 34; see also above, Chapter 3.1.4.3. 


\subsubsection{Do these types of usage infringe IP rights?}

First it should be noted that there is no relevant act of use carried out in relation to external objects of protection. Admittedly, an annotation is added to the marine biologist's database, but even if this database is protected by the sui generis right, it could only be infringed if its content were copied or made available to the public; in third-party provider scenario $A$, some data is added to the database but none of its content is copied or made available. However, the addition of data to the marine biologist's database could eventually lead to a co-ownership of the researcher of a potentially existing database right in such database ${ }^{343}$. Additionally, the potentially existing IP rights in the OpenAIREplus database may be infringed by the use of its content.

The VRE query mechanism directs the researcher to the content of OpenAIREplus through a link. It has already been shown that whether the linking of data infringes the database right or copyright depends on national case law ${ }^{344}$. Additionally, the extraction of data (a list of publications) by the researcher out of the OpenAIREplus database may constitute infringement of the sui generis right. The researcher copies the list of publications out of OpenAIREplus and makes it available to his colleagues. These actions would constitute relevant acts of extraction and making publicly available to the extent that that operation amounts to the transfer of a substantial part of the contents of the protected database, or to transfers of insubstantial parts which, by their repeated or systematic nature, would have resulted in the reconstruction of a substantial part of those contents ${ }^{345}$. The substantial nature of the taking is determined on a case-by-case basis. It would be of a substantial nature if it were of importance for the investment in the database creation $^{346}$.

It is rather unlikely that a single list of publications about a specific marine biological topic would form a substantial part of the database but it is not impossible that such a list would be quantitatively and/or qualitatively sufficient. Besides, if the marine biologists in third-party provider scenario $A$ repeatedly take lists of relevant publications as insubstantial parts of the OpenAIREplus database to round up their own database, it is possible that these takings could result in the reconstruction of a substantial part of the OpenAIREplus database's content, which is also not allowed without permission.

${ }^{343}$ Cf. on this, Chapter 3.1.4.3 and 3.3.4.4 above.

344 See above Chapter 3.3.3.2.2.

345 ECJ Case C-304/07, Directmedia Publishing GmbH v Albert-Ludwigs-Universität Freiburg (Directmedia), [2008] MMR 2008, 807.

346 Cf. ECJ Case C-203/02, British Horseracing Board Ltd v William Hill Organization Ltd (BHB), [2004]

ECR I-10415, para. 71. 


\subsubsection{Consequences}

No external IP rights are infringed in third-party provider scenario $A$, since no relevant acts are carried out in relation to external objects of protection.

Regarding the IP rights in OpenAIREplus there may be an infringement of the sui generis right by the extraction of data out of the OpenAIREplus database if the extracted part is sufficient to form a substantial part of the database's content or the insubstantial parts taken result in the reconstruction of a substantial part of the content.

Anyhow, it should be noted that even if the extraction of data out of the OpenAIREplus database did infringe IP rights, one of the goals of the project is to provide services such as described in third-party provider scenario $A$. Therefore, the rightholder of potential IP rights in OpenAIREplus is very likely to be willing to give his consent to such uses.

\subsubsection{Third-party provider scenario B}

OpenAIREplus, based on its advanced object interlinking mechanisms, generates a wealth of new information identifying and suggesting links among publications and/or research data. The Europe PMC e-Science data infrastructure explores this information via OpenAIREplus's APIs (e.g., OAI-PMH, OAI-ORE, Open Search, SRW/CQL, etc.) to transfer such information to Europe PMC 347 and allow its user community to consume it (e.g., named entity recognition for linking to the protein database UniProt).

\subsubsection{Which types of usage are relevant within the scenario?}

This scenario shows how an external subject-specific database (Europe PMC) can make use of the information contained in OpenAIREplus. The Europe PMC infrastructure extracts information from OpenAIREplus, transfers it to the Europe PMC database and makes it available to its users.

\subsubsection{Do these types of usage infringe IP rights?}

The actions carried out by Europe PMC potentially infringe the sui generis database right in OpenAIREplus. This right is especially infringed if a substantial part of the protected database is extracted (copied) or re-utilised (made available to the public).

In third-party provider scenario B, Europe PMC explores the information contained in OpenAIREplus, especially the suggested links between publications and/or research data. Via OpenAIREplus's APIs, Europe PMC transfers the data to the Europe PMC database. Through this transfer, Europe PMC copies the data

${ }^{347}$ Formerly known as PubMedUK. 
out of the OpenAIREplus database and stores it in its own memory. Afterwards, Europe PMC allows its user community to consume copied data and thereby makes it publicly available.

These actions of copying and making publicly available would infringe the sui generis right of OpenAIREplus if the data used formed a substantial part of the OpenAIREplus database. In third-party provider scenario B, the Europe PMC infrastructure explores and copies all relevant information of the OpenAIREplus database - a very significant amount of data. Thus it is very likely that a substantial part of the content of the OpenAIREplus database is used by Europe PMC.

Since Europe PMC is a scientific database, one could think about the application of the scientific research exception for its benefit. Such exception may be applicable if existing in the relevant national law, if the copying is carried out by a person for his own scientific use. But in third-party provider scenario $B$, the data is copied by Europe PMC, which is a legal entity, but not a person. It is not copying the data for its own scientific use, but the use of all of its users. Thus the scientific research exception is not applicable to Europe PMC. As a result, the sui generis right in the OpenAIREplus database is infringed by an unauthorised use as it is described in this scenario.

Furthermore, it could be discussed whether there could be copyright infringement if the data is copied out of the OpenAIREplus database. Even if the data taken is itself not protected by copyright, it is also possible that the structure of the database is an intellectual creation which deserves copyright protection. A database is protectable if, by reason of the selection or arrangement of its content, it constitutes the author's own intellectual creation ${ }^{348}$. There could then be a copyright infringement if the structure of the database is copied or imitated.

However, in the case of databases of research data, the relevant data are usually pre-existing and the aim of the database in such a context is a clear and flexible presentation of the data. Therefore the individual cannot choose which data he wants to fill the database, but has to use all data that is relevant in the scientific context. The structure of the database has to be clear and based on the scientific requirements. This does not leave much room for creativity or individual choices of the creator of a database for research data. It follows that databases of research data are usually not protectable by copyright. In the case of OpenAIREplus, the intention is to collect information about scientific publications. One single element is a record of a given publication; around this publication as much information as possible will be provided. Starting from this idea, there is no choice whether information is added to OpenAIREplus - if it is of any relevance to the publication, it has to be added. Since the process is not based on individual choices, the OpenAIREplus database is not protected by copyright.

348 Article 3(1) Database Directive. 
Since OpenAIREplus is potentially more than a normal database, but also a system of linking different kinds of data in a specific way and drawing conclusions out of it, it is theoretically possible that this system is copyright protectable in its own right, even if the database itself is not copyright protected. Copyright in such a system would especially be infringed if not only the data, but also in the process this system, were copied. For such a protection, the system of linking and ordering must constitute an intellectual creation of an author. In the case of OpenAIREplus, the idea of linking different kinds of data is not new or original. Indeed, such linking is already carried out by a number of databases. What really is remarkable is that OpenAIREplus aims at creating one single database for all fields of scientific research and not just one or a few specific subjects. Additionally, it directly asks users for their contribution through feedback functions and adds the possibility to upload their own data.

Even if this is generally a good idea, it is rather questionable whether a system that implies such functions forms an intellectual creation that is sufficient to gain copyright protection. Mere ideas are not protectable by copyright. There is probably more than one way to achieve the enabling of the additional functions, but this is more a technical matter than one of intellectual creativity. It follows that the system of specific linking and interaction of OpenAIREplus is not capable of copyright protection.

\subsubsection{Consequences}

The rightholder of the sui generis right in the OpenAIREplus database can prohibit the extraction and making available of substantial parts of its data by other infrastructures as in third-party provider scenario B. On the other side, subject-specific infrastructures such as Europe PMC need to be authorised to extract information from OpenAIREplus, transfer it to the Europe PMC database and make it available to its users. However, it is one of the goals of OpenAIREplus to exchange and mutually complement data between the generic infrastructure of OpenAIREplus and subject-specific infrastructures (such as Europe PMC). Therefore, OpenAIREplus should try to reach an agreement with subject-specific infrastructures such as Europe PMC on the mutual exchange of data between the respective databases.

The use on both the origin and destination databases of an Open Access licence that specifically includes the sui generis right in its scope, such as a Creative Commons 4.0 license, is advisable (see below Chapter 4 and 5.3 for details). 


\subsubsection{Third-party provider scenario C}

The Greek national organisation EKT-NHRF has undertaken the initiative of building the National Research Information System (CRIS) for the 18 universities in Greece, of which some are in the process of building their institutional repositories. Greece is active in the Seventh Framework Programme (FP7) (the Cordis portal shows 1050 projects) and it will be beneficial for the initiative to access the specific EC project information provided via the OpenAIREplus APIs. Moreover, in coordination with the current advancements in CRIS-OAR interoperability, publication-project objects could be retrieved from OpenAIREplus to be used in the newly developed institutional repositories (IRs).

\subsubsection{Which types of usage are relevant within the scenario?}

Third-party provider scenario $C$ is an example of the use of the content of OpenAIREplus by the CRIS of Greece and the IRs of the national universities. CRIS, as well as the IRs, access the content of OpenAIREplus (in this case EC project information and publication-project objects) and use it to complement their own data.

\subsubsection{Do these types of usage infringe IP rights?}

The exclusive rights of extraction and re-utilisation of the rightholder of the sui generis database right in the OpenAIREplus database could be infringed by the intended use of third-party provider scenario $C$.

CRIS and the IRs access a complete part of OpenAIREplus, such as the EC project information and incorporate it into the national databases. The act of accessing the data does not make the data available to others, but there would be a relevant act of copying where the accessed data is copied into another medium. In the process of accessing the data, it is potentially copied into the working memory of CRIS and the IRs. In addition to that, data of the OpenAIREplus database is permanently incorporated into the Greek national databases. This action requires a permanent storage in the national databases.

Since the data is copied out of OpenAIREplus and stored in another database there is a relevant act of extraction in terms of the sui generis database right. This act of extraction would infringe the sui generis right of OpenAIREplus if the data used formed a substantial part of the OpenAIREplus database. Whether such a part is substantial or not is decided by the courts on a case-by-case basis. But since complete parts of the OpenAIREplus data are used in third-party provider scenario $B$ (in this case EC project information and publication-project objects), it is very likely that this part will form a substantial part of the OpenAIREplus database. As 
a result, an unauthorised use of the OpenAIREplus data as described in this scenario infringes the sui generis right of the rightholder in the OpenAIREplus database.

Since CRIS and the IRs are also databases for scientific use, it is questionable whether the scientific use exception is applicable in the case of third-party provider scenario $C$. Such exception is applicable if the relevant national legislation provides for it and if the copying is carried out by a person for his own scientific use.

In third-party provider scenario $C$, the data is copied by CRIS and the IRs as legal entities, but not by a person and thus they cannot copy data for their personal use, but do so for the use of all of their users. So, the scientific research exception is not applicable to CRIS and the IRs in this scenario.

Another issue arises when the data that is copied out of the OpenAIREplus database is also copyright protected, such as full text articles. In these cases, there would be infringement of the copyright existing in these documents if they were copied by CRIS and the IRs without the consent of the copyright holders of the articles.

\subsubsection{Consequences}

The rightholder of the sui generis right to the OpenAIREplus database can prohibit a use such as is described in third-party provider scenario $C$. The Greek initiative, on the other hand, needs to be authorised by the rightholder of the database right in the OpenAIREplus database to use the data of OpenAIREplus as it is intended in this scenario. If some of the copied data is also copyright protected, the consent of the copyright holder is also required.

One of the goals of the OpenAIREplus project is to establish connections not just with other research infrastructures, but also with several diverse forms of research content systems (such as CRIS). OpenAIREplus aims at establishing interoperability between external research content systems and its infrastructure in order to enable the mutual harvesting of resources. OpenAIREplus and the Greek initiative should ideally agree on the mutual exchange of data between both resources.

Since such free exchange is at risk if copyright holders in some content of OpenAIREplus can prohibit the circulation of their data, it should be clarified in the terms and conditions of OpenAIREplus that the further circulation of copyright-protected data that is uploaded to OpenAIREplus is permitted.

The use on both the OpenAIREplus and Greek national databases of an Open Access licence that specifically includes the sui generis right in its scope, such as a Creative Commons 4.0 license, is advisable (see below Chapter 4 and 5.3 for details). 


\subsubsection{Third-party provider scenario D}

In the Netherlands all universities and the Royal Netherlands Academy of Arts and Sciences use the same CERIF-compliant research information system, called METIS. In the open access part information on research projects, including their output, may be found. Possible types of output include datasets, articles, conference papers and presentations. The NARCIS system, which is used as an aggregator for OpenAIREplus and maintained by DANS, harvests metadata from METIS, publication repositories and dataset repositories. When metadata of these different sources shares a common metadata element, for instance the EU project code, NARCIS is able to show the relationships between research projects, organisations, researchers and research output.

\subsubsection{Which types of usage are relevant within the scenario?}

Third-party provider scenario $D$ shows how metadata is harvested from METIS and other repositories in the Netherlands by an aggregator for OpenAIREplus (NARCIS). After harvesting, the metadata is stored in OpenAIREplus and NARCIS is able to show which documents share a metadata element, e.g. which data belongs to a specific EU project code. Within this scenario, data from different sources (repositories) is accessed and copied into OpenAIREplus. If requested, the relationships between the data are shown.

\subsubsection{Do these types of usage infringe IP rights?}

The actions of harvesting metadata carried out by NARCIS in this scenario could especially infringe the sui generis right of the different repositories. If some of the metadata is protected by copyright, the harvesting could also infringe copyright. Copyright protection of metadata is rather unlikely but cannot be ruled out, especially in the case of some longer texts or descriptions.

At first NARCIS accesses the open access part of the repositories. The accessing would constitute a relevant act of copying if the accessed data were copied into another medium, such as the working memory of NARCIS. Secondly, the metadata is copied out of the repositories and stored in OpenAIREplus. The storing of data in the working memory, or the permanent storage in OpenAIREplus are relevant acts of copying.

Since OpenAIREplus is going to be a database for research data, one could think about the application of the scientific research exception. Such exception is applicable if the relevant national legislation provides for it and if the copying is carried out by a person for his own scientific use.

However, in third-party provider scenario D, the data is copied by OpenAIREplus and not a person. In addition, the data is not copied for a person's own scientific use, but the use of all users of OpenAIREplus. Thus the scientific research exception is not applicable in this case. 
In so far as the copied data is part of a sui generis protected database, the extraction would infringe this right if the data used formed a substantial part of the repository database or if insubstantial parts of a database were repeatedly taken and these parts amounted to the taking of a substantial part.

Whether such a part is substantial or not is decided by the courts on a case-bycase basis, but since NARCIS systematically accesses and copies metadata out of repositories, it is very likely that the amount of the copied data will form a substantial part of the content of the repositories ${ }^{349}$.

Furthermore, NARCIS shows relationships between the data. As has already been pointed out, it is not entirely clear on the European level whether the linking of data is generally a relevant act of re-utilisation or not ${ }^{350}$.

Since NARCIS acquires a substantial amount of data to be integrated into OpenAIREplus, it is also worth thinking about co-ownership by NARCIS of the sui generis right in OpenAIREplus. However, according to EU law, to gain sui generis protection, an investment in the creation of the database itself is required and not merely in the creation or provision of data ${ }^{351}$. NARCIS only invests efforts in the acquisition of metadata for OpenAIREplus, not the creation of the database itself. Thus NARCIS does not become a co-owner of the sui generis right. As a result, the harvesting of metadata as carried out by NARCIS would infringe copyright, as far as the copied data is copyright protected, and also the sui generis right of the repository databases.

\subsubsection{Consequences}

Without an agreement with the repositories on the copying of their data, OpenAIREplus is not allowed to harvest their data and copy it into the OpenAIREplus database. The rightholders of the sui generis right in the repositories databases or the potentially existing copyright in individual elements of the databases' content can prohibit the harvesting of their content. As it is one of the goals of the project to enable the mutual harvesting of resources between OpenAIREplus and external sources, it is very important to reach an agreement with the different repositories on the mutual use of databases. The use on both the origin and destination databases of an Open Access licence that specifically includes the sui generis right in its scope, such as a Creative Commons 4.0 license, is advisable (see below Chapter 4 and 5.3 for details).

\footnotetext{
${ }^{349}$ For the counter-example, the extraction of metadata out of the OpenAIREplus database, see above, Chapter 3.3.6 and 3.3.7.

${ }^{350}$ See above Chapter 3.3.1.2.2.2.

351 Cf. ECJ Case C-203/02, British Horseracing Board Ltd v William Hill Organisation Ltd, [2005] ECDR 1,1 , para. 34 .
} 


\subsubsection{Content provider registration and data processing scenario}

OpenAIREplus allows for the registration of content providers (for metadata about research literature, research data and research information (e.g. about funded projects)). The OpenAIREplus workflow supports the aggregation, storing and processing (in terms of text mining) of the metadata. The processing pipeline (in the so-called "Information Inference Service") may follow links (given in the metadata) to capture other resources (e.g. the full text) and may lookup metadata from authoritative sources (e.g. from crossref.org).

The extracted information is stored (either temporarily like the full text, or permanently like the metadata) in OpenAIREplus and used to create links between publications, datasets and related research information. The resulting graph of linked entities is exposed via OpenAIRE APIs and used in the "Enhanced Publication" Management for end users.

\subsubsection{Which types of usage are relevant within the scenario?}

Text mining is one important tool to generate data for OpenAIREplus. The Content provider registration and data processing scenario shows the intended workflow of how data will be incorporated into OpenAIREplus by aggregation, storing and text mining. In this scenario, information is accessed, extracted from content providers and other sides, stored temporarily or permanently in OpenAIREplus and used to create links between different kinds of data.

\subsubsection{Do these types of usage infringe IP rights?}

The use as described in this scenario could eventually infringe on the sui generis right existing in the scientific databases of the repositories or the copyright of the full text articles. At first OpenAIREplus accesses the data of the content providers. Such accessing is a relevant act of copying, if the accessed data is copied into another medium, such as the working memory of OpenAIREplus.

The creation of links between publications, datasets and related research information could constitute a relevant act of making available to the public. Whether the linking of information that is available on the internet is an act of making publicly available has not been clarified yet. There are national decisions which state that linking is generally not a relevant act and on the other hand, there are decisions in national case law that at least deep linking of information can constitute a relevant act of publicly making available ${ }^{352}$. However, the actual reference to the ECJ ${ }^{353}$ will hopefully clarify this issue finally.

Additionally, according to the scenario, the accessed data is copied into OpenAIREplus, either temporarily (like the full text) or permanently (like the

\footnotetext{
352 See above Chapter 3.1.2.

353 ECJ Case 466/12, Svensson et al v Retreiver, Reference of 18 October 2012.
} 
metadata). This means that relevant data is stored temporarily or permanently in the memories of OpenAIREplus. This copying infringes on the right of reproduction (copyright) or the right of extraction (database right), respectively.

A relevant act of copying in the frame of the sui generis right additionally requires the use of a substantial part of a database. In the Content provider registration and data processing scenario, metadata is taken systematically and comprehensively from other content providers, so that it is very likely that the data used amounts to a substantial part of the database content in terms of the sui generis right. As a result, the storing of the extracted information in OpenAIREplus, regardless of whether temporary or permanent, may infringe the right of reproduction where the copied data is protected by copyright or the right of extraction if data is taken from a sui generis-protected database.

\subsubsection{Consequences}

It is necessary to obtain permission from the respective rightholders of the sui generis right or copyright to copy the information (in this case metadata or full text articles) out of the databases of the content providers and store them temporarily or permanently in OpenAIREplus.

The rightholders of the copyright in the full text articles and the database right in the databases of metadata are able to prohibit the use as it is described in this scenario.

Since text mining is one of the key features of OpenAIREplus, it is essential to reach an agreement with other content providers on the exchange of data. Therefore, the use on both the origin and destination databases of an Open Access licence that specifically includes the sui generis right in its scope, such as a Creative Commons 4.0 license, is advisable (see below Chapter 4 and 5.3 for details).

\subsubsection{Additional thoughts}

One could think about the question whether a content provider who registers his data to be used and implemented in OpenAIREplus becomes a co-owner of the sui generis right in the OpenAIREplus database. This would be the case if the registration of the data constituted a substantial investment in the creation of the database and the provider thereby carried the economic risk for the creation of the database.

Regarding the content provider, one must note that he has potentially invested into the creation of his data, but that he does not carry any risk in relation to the creation of the OpenAIREplus database. Thus, even if a content provider agrees to implement his data into OpenAIREplus, he is not becoming a co-owner of the suigeneris right in the OpenAIREplus database. However, if data which is uploaded to OpenAIREplus by a content provider is also copyright protected, such as full text articles or longer descriptions, there would be infringement of such copyright 
if the data were used, copied and made available through OpenAIREplus. Since the further use of such data is at risk, if the copyright holder in such data can prohibit the further use of it, there should be a clarification in the terms and conditions of OpenAIREplus, that a licence for the further use of uploaded copyright data is granted to OpenAIREplus.

Another question is whether there are any IP rights existing in the graph of linked entities, which is explicitly mentioned in this scenario. Since the graph is a tool of OpenAIREplus to show the links between different kinds of data, it is part of the OpenAIREplus database. But it is questionable whether there is any IP right existing in the graph itself.

Copyright protection is also conceivable. At first one could ask whether the graph is created by the user who enters a specific request. However, the graph is the result of the processing of data within OpenAIREplus and thus not created by the user himself. So it is questionable whether the graph is actually an expression of the underlying software or the database system. Since the graph does not show how the software works but merely which data is contained in the database, it is not an expression of the software. But secondly, the graph shows connections between publications, datasets and related research information, and thus possibly the structure of the database, or the system of linking different kinds of data in a specific way and drawing conclusions out of it. If the structure of the database, or the system of linking itself, is copyright protectable, the graph that reveals the work behind it could potentially fall under such copyright protection.

For a copyright protection of the graph, the structure or the system of linking and ordering behind it must constitute an intellectual creation of an author. However, as already shown, neither the structure nor the system of specific linking of OpenAIREplus is capable of copyright protection ${ }^{354}$. Thus the graph itself is not protected by IP rights but just as part of a protected database.

${ }^{354} \mathrm{Cf}$ hereto in detail above, Chapter 3.3.6.2. 



\section{Analysis of licensing issues}

\subsection{Overview}

"Public Access" means that the public has access to a huge amount of information (otherwise probably only accessible for a substantial fee). However, as this does not imply reuse, it becomes clearer why Open Access (OA) is the avenue that should be pursued by funding entities that want to benefit society at large with their moneys and subsidies, usually coming from the general taxation system. Only through reuse is it possible to achieve the benefits of Open Access, both in terms of social desirability and economic growth and innovative business models.

The "legend" goes that Open Content (OC) was first coined by David Wiley in 1998, when - while discussing with Free Software guru Richard Stallman, and before the latter developed the Free Document Licenses - he created the Open Content License (OPL). The OPL version 1 of 1998 was a copyright licence granting permissions to copy, redistribute and create derivatives of the original and distribute them provided that the same licence applies and only for noncommercial activities (limited fees could be requested for handling or media costs) ${ }^{355}$.

Over the years, the meaning of Open Content evolved and many licences are referred to as Open Content, although a strict definition of the minimum conditions for qualification is not clearly established" 356 . In general terms, the "4Rs framework" is the reference model: Reuse, Revise, Remix, Redistribute ${ }^{357}$. As specified by the drafter, the more a content meets those requirements, the more open it is.

Open Access, on the contrary, has better defined boundaries, and was developed more recently within the academic environment with the goal of framing a new paradigm (or recovering a very old one) in the production, validation and dissemination of knowledge ${ }^{358}$. The idea on which Open Access relies is that the knowledge produced by academic and scientific institutions has to be accessible by the academic community and society at large without economic, legal or technological restrictions. Accessibility in Open Access is defined as the right to access, use, copy, redistribute, communicate to the public, and distribute derivative works under the sole requirement of the acknowledgement of paternity (although some other minor restrictions might be considered acceptable depending on the specific envi-

\footnotetext{
355 Available at http:/ /opencontent.org/opl.shtml (last accessed 06/2013).

356 The same OPL was updated to the Open Publication Licence in 1999, which allowed for commercial uses and had a set of disposable clauses.

357 See http:/ /opencontent.org/definition (last accessed 06/2013).

358 For a brief historical excursus see https://en.wikipedia.org/wiki/Open_access\#History (last accessed 06/2013).
} 
ronment or definition) ${ }^{359}$. It is important here to note that unlike Public Access (such as the NIH policy), Open Access requires that all the materials need to be not only accessible but also reusable, in terms of the ability to make copies and redistribute them.

The term "Open Access" was first formally defined at a meeting in Budapest in early December 2001. Out of that meeting came the so-called Budapest Open Access Initiative 360 and "Open Access" was defined as the
free availability of scientific literature on the public internet, permitting any users to read, download, copy, distribute, print, search, or link to the full texts of these articles, crawl them for indexing, pass them as data to software, or use them for any other lawful pur- pose, without financial, legal, or technical barriers other than those inseparable from gain- ing access to the internet itself. The only constraint on reproduction and distribution, and the only role for copyright in this domain, should be to give authors control over the integ- rity of their work and the right to be properly acknowledged and cited.

The Budapest Open Access Initiative was followed up some 15 months later by the Bethesda Statement ${ }^{361}$, which came out of a one-day meeting of scientists, funding agencies, librarians, scientific societies and publishers, held in April 2003. In October of the same year, the Max Planck Society in Germany convened a meeting on "Open Access to Knowledge in the Sciences and Humanities". This meeting widened the discussion to include the humanities and produced the "Berlin Declaration on Open Access"362.

Open Access contributions include original scientific research results, raw data and metadata, source materials, digital representations of pictorial and graphical materials and scholarly multimedia material. On the basis of these statements and initiatives, the three following essential characteristics of Open Access emerge: free accessibility, further distribution, and proper archiving 363 . The Berlin Declaration gives a definition of which contributions qualify as Open Access, i.e. those that satisfy the following two conditions:

a) The author(s) and right holder(s) of such contributions grant(s) to all users a free, irrevocable, worldwide, right of access to, and a license to

\footnotetext{
${ }^{359}$ See for example the Budapest Open Access Initiative of 2002 available at http://www.soros.org/openaccess/read; the Berlin Declaration on Open Access to Scientific Knowledge of 2003 available at http://oa.mpg.de/lang/en-uk/berlin-prozess/berlinererklarung, or the Bethesda Statement on Open Access Publishing of 2003 available at www.earl ham.edu/ peters/fos/bethesda.htm; see also OECD 2004 http://www.oecd.org/document/0, 3746,en_21571361_44315115_25998799_1_1_1_1,00.html (all last accessed 06/2013).

360 Available at: http://www.opensocietyfoundations.org/openaccess (last accessed 06/2013).

361 Available at: http://www.earlham.edu/ peters/fos/bethesda.htm (last accessed 06/2013).

362 Available at: http://oa.mpg.de/lang/en-uk/berlin-prozess/berliner-erklarung (last accessed 06/2013).

363 Open Society Institute, Open Access Publishing and Scholarly Societies - A Guide, New York, OSI, 2005 , p. 6.
} 
copy, use, distribute, transmit and display the work publicly and to make and distribute derivative works, in any digital medium for any responsible purpose, subject to proper attribution of authorship (community standards will continue to provide the mechanism for enforcement of proper attribution and responsible use of the published work, as they do now), as well as the right to make small numbers of printed copies for their personal use.

b) A complete version of the work and all supplemental materials, including a copy of the permission as stated above, in an appropriate standard electronic format is deposited (and thus published) in at least one online repository using suitable technical standards (such as the Open Archive definitions) that is supported and maintained by an academic institution, scholarly society, government agency, or other wellestablished organisation that seeks to enable open access, unrestricted distribution, interoperability, and long-term archiving.

Since the lack of access to complete literature can seriously impede advances in knowledge, the main thrust of the Declaration lies in the creation of a new "Open Access" business model for scientific publishing or, absent this, of institutional repositories where all scientific and scholarly publications are to remain freely accessible. According to the Berlin Declaration, the only constraint on reproduction and distribution of articles should be to give authors control over the integrity of their work and the right to be properly acknowledged and cited. The principles set out in the Berlin Declaration are primarily aimed at governments, universities, research institutions, funding agencies, foundations, libraries, museums, archives, learned societies and professional associations. Remarkably, neither publishers nor authors are listed in this enumeration.

Admittedly, because the Berlin Declaration's main goal is to increase access to scientific knowledge, whether through the "Green" or "Golden" road of Open Access $^{364}$, the Declaration is silent on the precise extent to which reuse of scientific works is permissible.

Of course, the absence of a universally accepted definition of Open Access does not make things easier. But in other contexts, like software, cultural heritage and governmental sectors, the possibility to reuse the licensed material is considered to be one of the main characteristics of the "open" ideology. Principle 3 of the Open Source Definition states that "the licence must allow modifications and

\footnotetext{
364 The "Green Road" to OA is based on a "subscriber-pays model" where pre-print/post-prints of articles are deposited in an institutional repository often after an embargo period, while the "Golden Road" to OA is based on an "author-pays model" - see L. Guibault, "Owning the Right to Open Up Access to Scientific Publications", in L. Guibault and C. Angelopoulos (eds.), Open Content Licences: From Theory to Practice, Amsterdam, Amsterdam University Press, 2011, pp. 137-67, 157.
} 
derived works, and must allow them to be distributed under the same terms as the licence of the original software" 365 . Strongly inspired by the definition of "free software" developed by the Free Software Foundation" 366 , the definition of "Free Cultural Works" declares that:

works of authorship should be free, and by freedom we mean:

- the freedom to use the work and enjoy the benefits of using it

- the freedom to study the work and to apply knowledge acquired from it

- the freedom to make and redistribute copies, in whole or in part, of the information or expression

- the freedom to make changes and improvements, and to distribute derivative works ${ }^{367}$.

In other words, Free Cultural Works are defined as "works or expressions which can be freely studied, applied, copied and/or modified, by anyone, for any purpose". The European Directive on the reuse of public sector information, although not applicable to scientific information, states that "licences should not unnecessarily restrict possibilities for reuse or be used to restrict competition" 368 . In comparison to these movements, the Berlin Declaration also promotes the fourth freedom within the scientific sector, i.e. the freedom to make changes and improvements and to distribute derivative works.

Establishing Open Access as a worthwhile procedure ideally requires the active commitment of each and every individual producer of scientific knowledge. To date, the Berlin Declaration has been signed by more than 400 organisations worldwide. Among the reasons for such a push in Open Access is the fact that most of the research developed by academic institutions is possible thanks to public funds, i.e.,taxpayers' money. Under this assumption, to charge a second time to access a scholarly article for which a researcher (who is also a taxpayer) or any other member of society has already borne the cost represents a nonsense. All the more because this money usually does not go to the author or academic institution (thus furthering other research) but to a private company (the publisher) whose activity is certainly not that of paying a salary to the author/researcher, but that of organising the review of the content of the publication (usually thanks to peers from other academic institutions who review articles as part of their acade-

\footnotetext{
365 See: http://opensource.org/docs/osd (last accessed 06/2013).

366 See: http://www.gnu.org/philosophy/free-sw.html (last accessed 06/2013).

367 See: http:/ / freedomdefined.org/Definition; see also the vision of the Open Knowledge Foundation: http://okfn.org/about/our-vision (both last accessed 06/2013).

368 Directive 2003/98/EC of 17 November 2003 on the reuse of public sector information, OJ L $345 / 90,31.12 .2003$.
} 
mic activities, without receiving any payment) and its dissemination (a concept that is undergoing a deep rethink after the adoption of new technologies and the internet).

The evolution of the information society, which has witnessed in the last few years, inter alia, an extreme reduction of the cost of computational and storage devices as well as the evolution of network capabilities, has made possible - in the field of academic publishing - the publication of online papers and articles, but also - and this is particularly relevant in the hard sciences - the entire datasets that have been gathered as the basis of the published article. This is a tremendous step forward for the improvement of the quality, verification and validation of scientific publications.

In addition, the availability of all these datasets, which are linked back and forth to the relevant paper, also allows the constant "growth" of the publication. From the same dataset different experiments are possible, and new meanings and correlations can be discovered. In fact, the online presence of such information allows (if the proper licence is chosen) other researchers, including those coming from very different fields, to perform a huge variety of statistical processing, or any other type of analysis from a given dataset, or from a combination of a number of them, never previously correlated. This is responsible for a completely new way of looking at data coming from different sectors, allowing the possibility to create new value from "old" data, by just combining it in ways unknown or unforeseen by the original gatherer of the datasets. Data mining is the buzz phrase coined for such activities, which include proper data mining (which identifies a specific statistical methodology) together with other forms of automated data analysis and comparison. The potential of such a new approach to the analysis of the knowledge produced, and the constant improvement of publications by adding updates, comments, tables and so forth (enhanced publications) is unprecedented for the quantity and quality of new knowledge that can be produced by information that is in many cases already available.

However, a major problem in this idyllic scenario is that the information that could seem available (because it exists, or is accessible through a website or database, etc.) is not accessible after all, having been published under conditions that not only restrict its access and reusability, but also the very same act of analysing it. It must be borne in mind that activities such as data mining usually presuppose the (temporary) copy - or extraction in the case of the SGDR - of the dataset into the analyser's machine, an activity that - as seen above - is reserved by the law to the maker of such datasets, and which can be further restricted contractually ${ }^{369}$. It should further be recalled that in the case of the SGDR, the EU legislator has not

${ }^{369}$ See for example the Public Access policy of PubMed Central, above at fn. 7. 
deemed it necessary to implement the only mandatory exception in the field of copyright, i.e. temporary copies with no independent economic relevance, ex Article 5 Info Directive ${ }^{370}$. Consequently, the lawful user of a database will not be able to temporarily copy the entire database in order to perform an analysis of the recurrence of a given term or condition in the database for which he has obtained lawful access: either the database (usually web-based) offers such functionality by its own, or such a search will violate the SGDR.

The next sections are dedicated to the legal analysis of the requirements and conditions to which the articles and dataset are subject and how to pursue a real Open Access path towards it.

\subsection{Contracts}

The uncertainty arising from the complex rights status of scientific research data under European law can, to some extent, be alleviated through the use of contracts. Setting standardised contractual conditions of use lowers transaction costs between rights owner and users and eases the reuse of information, even in cases where the determination of rights can be problematic. On the other hand, if no rights attach to a scientific database or its content, then there is no ground for licensing at all. This certainly explains why American research institutions, like the Harvard-MIT Data Center, do not display any licensing terms in relation to the data they make available for public use: section 102(2) of the US Copyright Code expressly states that "in no case does copyright protection for an original work of authorship extend to any idea, procedure, process, system, method of operation, concept, principle, or discovery, regardless of the form in which it is described, explained, illustrated, or embodied in such work". Moreover, "Compilations" (or databases) are protected pursuant to section 101 of the Code only in so far as the elements assembled are selected, coordinated or arranged in such a way that the resulting work as a whole constitutes an original work of authorship. In consequence, US law does not recognise any equivalent to the European sui generis database right.

Since the legal status of scientific databases and their content is more difficult to assess under European law, the use of standard licences would eliminate the need for the user to look for the rights owner and to negotiate the terms of use. To foster the widest access and reuse of scientific publications and data, policymakers are now pushing for Open Access conditions.

Several existing standard-form licences are already used in the context of Open Access publishing, including the Creative Commons licences, the Open Data Commons and the Digital Peer Publishing Licence. In the following, we will evaluate whether these licences meet the requirements of the Open Access principles

${ }^{370}$ See Article 5(1) Info Directive. 
and which of these is the most suitable for the dissemination of scientific information.

\subsubsection{Creative Commons Licences}

In the Open Access environment, the Creative Commons (CC) licensing system is the most widely used set of licences because it offers a series of easy-to-use, standardised and automated licences, which authors can affix to their work in order to indicate under which conditions it may be used. Thanks to these licences, it is no longer necessary for users to contact the rights holder prior to every use of the work to find out what can or cannot be done with the work. The work is, therefore, made available to everyone in accordance with the conditions of the chosen CC licence. Of the main CC licences, the Creative Commons Public License (CCPL) is by far the most popular. Besides the four core stipulations (Attribution (BY), Non-Commercial (NC), No-Derivatives (ND) and Share Alike (SA)), a number of fundamental principles lie at the basis of the CCPL license. Taking into account the conditions of the chosen licence, the licensor grants the user a worldwide, non-exclusive, perpetual (for the duration of the applicable right) licence to reproduce, display, perform, communicate and distribute copies of the work. All rights may be exercised in all media and formats whether now known or subsequently devised. The above rights include the right to make such modifications as are technically necessary to exercise the rights in other media and formats. In principle, all rights not expressly granted by the licensor are reserved. All CC licences are irrevocable. This means that at the moment the work is distributed under a CC licence on the internet, the author can no longer change his mind or withdraw the licence. It is in his power to stop distributing or making available his work under a CCPL (or any other CC licence), however the copies already available under the original CC licence will maintain such status. Another obligation for the user is to add a copy of, or a link to, the underlying CC licence in the form of the Uniform Resource Identifier for the applicable CC licence to each copy of the work that he distributes, communicates or makes available to the public $^{371}$.

It is also important to note that, in principle, the CC licence system makes no distinction between digital and analogous works, or between several types of copyright-relevant acts, such as the act of reproduction or communication to the public. Article 2 of each CC licence provides that nothing in the licence is intended to reduce, limit or restrict any uses free from copyright or rights arising from limitations or exceptions that are provided for in connection with the copyright protection under copyright law or other applicable laws. Moreover, the licensor may not

\footnotetext{
371 See the text of the Creative Commons Attribution 3.0 Unported Licence at: http://creativecomm
} ons.org/licenses/by/3.0/legalcode (last accessed 06/2013). 
apply any effective technological measures to the work that restrict the ability of a recipient of the work to exercise the rights granted under the terms of the licence.

Creative Commons licences are widely used to disseminate scientific publications under Open Access principles. For example, all publications made available through the OAPEN Library ${ }^{372}$, Hindawi Publishing ${ }^{373}$, the Public Library of Science (PLoS) ${ }^{374}$, or in BioMed Central ${ }^{375}$ are distributed under either one of the six core CCPL variations. BioMed's summary of the agreement states that:

anyone is free: to copy, distribute, and display the work, to make derivative works, to make commercial use of the work, under the following conditions: the original author must be given credit for any reuse or distribution; it must be made clear to others what the licence terms of this work are.

A joint Creative Commons Nederland/SURFdirect report recommended the use of the CCPL Attribution 3.0 License above all other licences or other combinations of CCPL licences, for this licence is the most in line with the principles of Open Access, while putting no obstacles in the way of the further reuse of research results, and still requiring that proper attribution be given to the author and that derivative works be identified as such ${ }^{376}$. The application of a Non-Commercial and a Share Alike clause could hinder the reuse of scientific publications and would generate potential incompatibilities between scientific projects, especially those which are partly commercial.

The use of CC licences in relation to scientific databases and their contents can lead to some issues. The main reason lies in the Creative Commons organisation's firm belief that "scientific data should be freely available to everyone", as a result of which the application of the core six CC licences to databases is, from a European perspective, far from optimal ${ }^{377}$.

CC licences are translated and adapted to the laws of many jurisdictions in the world (to date in more than 50 jurisdictions worldwide). National jurisdictions are able to "port" the CC licences to their local legal system based on "unported" licences, which are in principle jurisdiction-agnostic: they do not mention any particular jurisdiction's laws or contain any sort of choice-of-law provision. While versions 1.0 and 2.0 of the "unported" licence (previously known as the "generic" licence) were based on the provisions of the US Copyright Act, version 3.0 of the "unported" licence is instead based on the provisions of the Conventions of

\footnotetext{
372 See: http://www.oapen.org/home (last accessed 06/2013).

373 See: http://www.hindawi.com (last accessed 06/2013).

374 See: http://www.plos.org (last accessed 06/2013).

375 See: http://www.biomedcentral.com (last accessed 06/2013).

376 P. Keller and W. Mossink, "Hergebruik van materiaal in onderwijs - en onderzoekomgevingen", Utrecht/Amsterdam: Creative Commons Nederland and SURFdirect, March 2009, p. 31 available at http:/ / www.creativecommons.nl/downloads/090323SURFCC_Hergebruik_van_materia al.pdf (last accessed 06/2013).

377 See: http:/ / creativecommons.org/science (last accessed 06/2013).
} 
Berne and Rome ${ }^{378}$. Since the database right is a purely European phenomenon with few exceptions - it is not surprising to note that databases are only indirectly covered by the unported Creative Commons License version 3.0. The definition of "Work" under the licence includes the "literary and/or artistic work offered under the terms of this License including without limitation any ... compilation of data to the extent it is protected as a copyrightable work". No explicit reference is made to the European database right.

When porting the CC licences to their national law, several European jurisdictions took it upon themselves, for the sake of completeness, to include databases as a subject matter of the licences. This is the case in the Netherlands, Germany, France and Belgium where version 2.0 also added "extraction and re-utilisation" of substantial parts of a database in the version 2.0 rights grant, as the equivalent to the right of reproduction, performance and distribution for works covered by copyright and neighbouring rights. This European initiative was not seen favourably by the founders of the Creative Commons licences: first, because the licences are said to protect the fruits of creative effort and not merely investment; secondly, because since the database right is purely European, its inclusion in the licences could lead to legal uncertainty for database makers residing outside of Europe; and thirdly, because there was a fear that some licensors would try to contractually claim protection on databases, thus "importing" the database right, in jurisdictions that do not recognise it ${ }^{379}$.

Consequently, a compromise was reached before version 3.0 was to be ported anywhere in Europe: the SGDR was to be waived in all European licences. For example, the Dutch definition of "work" still covers

the copyrightable work of authorship put at disposal under the terms of this Licence. For the purposes of this Licence a Work should also be taken to mean the phonogram, the first recording of a film and the (broadcasting) programme in the sense of the Neighbouring Rights Act and the database in the sense of the Database Act, insofar as such phonogram, first recording of a film, (broadcasting) programme and database is protected under the applicable law within the User's jurisdiction.

However, the licence elements requirements (Attribution, Non-Commercial, NoDerivatives, and Share Alike) are no longer applied to database rights. This follows from Article 4 subparagraph (e) of the European transposition of the licence, which reads:

"For the avoidance of doubt, it must be noted that the aforementioned restrictions (paragraph 4(a), paragraph 4(b), paragraph 4(c) and paragraph 4(d) do not apply to those parts of the Work that are deemed to fall under the definition of the "work" as stated in

\footnotetext{
${ }^{378}$ C. Maracke, 'Creative Commons International', JIPITEC: Journal of Intellectual Property, Information Technology and E-Commerce Law (2010) 1(1), pp. 4-18.

${ }^{379}$ Ibid., p. 10.
} 


\section{this License solely on account of compliance with the criteria of the sui generis database} law under national law implementing the European Database Directive."

Under version 3.0, database rights have been effectively removed from the scope of the licences. As a result, the optional licence elements lose their effect and cannot be applied to databases, in so far as they are protected under the sui generis regime 380 . Thus, the licensor of a database licensed under an Attribution Share Alike Netherlands 2.0 license will expect derivatives to carry the Share Alike element and stay in the Commons. However, the Share Alike interoperability clause allows that any derivative of the database may be relicensed under a licence which may state that the licensing restrictions, including Share Alike, cannot be applied to a database. Therefore, the second derivative will not be shared with the Share Alike element, and the original licensor's expectation will be disappointed as far as Attribution, No-Derivative, Non-Commercial and Share Alike are concerned: these restrictions will not be applied.

In principle, all six possible combinations of the CCPL licence meet the Open Access principles of free accessibility, further distribution, and proper archiving. All CCPL combinations also guarantee proper attribution of the author, in application of the mandatory "Attribution" licence element; and the No-Derivative licence element allows the author to permit only verbatim redistributions of the work. However, the CC-No-Derivative licence does not meet the Open Access criterion of the freedom to make changes to the licensed work as is discussed above in Chapter 4.1.

At this time, the core Creative Commons licensing suite is not the appropriate instrument to license scientific databases and their content, even for those who wish to use the most liberal licence (CC-Attribution License). The fact that the SGDR is waived takes away all usefulness of the licences for the purpose of disseminating scientific research results under specific conditions. Scientific research institutions that wish to allow the reuse of a substantial part of their database on the condition that they receive attribution for the use of their data are frustrated in their intention, for version 3.0 explicitly disallows this possibility. The same holds true for the wish of the database maker to limit third parties from making a commercial use of or a derivative product from a substantial part of the database.

Since the porting of version 3.0 in Europe, Creative Commons' treatment of the SGDR has been criticised on two counts: first, because if someone applies an international licence to a database from a country that recognises sui generis database protection, there is a possibility they are not granting licensees any rights to use the database in a way that implies the SGDR. Licensees may not realise that they could need extra permissions to use a substantial portion of the licensed database in the EU and a few other jurisdictions. Secondly, it appears that in prac-

${ }^{380}$ L. Guibault, 'Creative Commons Licenses: What to Do with the Database Right?', Computers and Law (2011) 21(6), p. 3. 
tice, a number of European institutions have refrained from using CC licences because they do not want to waive the SGDR. Therefore the mandatory waiver of the SGDR described above can to some extent be seen as an obstacle to the widespread use of the CC licensing system in Europe.

In view of the problems with the waiver of the SGDR, Creative Commons decided to address, among other issues, the specific question of the database right leading to a new version 4.0 of the licensing suite. Stepping back from its previous position, Creative Commons declared its intention to license database rights from now on, under the same terms and conditions as copyright. The organisation feels that "this is the best way to ensure that database rights are not a barrier to wouldbe licensors seeking to exercise those rights, or to those using CC-licensed works, who might otherwise need to ask for separate permission to use the work as intended" 381 . An effort is being made to clarify the fact that database rights (like all licensed rights) are only within the scope of the licence if they are held by the licensor and apply to use of the licensed work by the licensee. One of the goals of version 4.0 is to craft a licence suite that allows use of the work consistent with the expectations of both licensors and licensees (and rights closely related to copyright may impede that). The permissions granted by the licences may need to account for other laws that grant copyright-like rights in a particular subset of jurisdictions (such as SGDR). Copyright-like rights are those rights that overlap with the exclusive rights of copyright and are exclusively held by the same person as the copyright. The drafting process of version 4.0 started in September 2011 and a final text of version 4.0 is expected to be officially launched in the course of 2013. The proposed changes regarding the SGDR should make the CC licence suite suitable to license not only scientific publications but also the related research data, all with one single instrument.

Until version 4.0 of the core CC licensing suite is up and running, rights owners in works and other types of information, such as scientific research data, have the possibility to relinquish their rights through another legal tool: the Creative Commons Zero Universal Dedication 1.0 (CC0 $)^{382}$. CC0 is a legal tool that operates as a waiver of copyright and related or neighbouring rights (including the sui generis right and moral rights) to the fullest extent permitted by law. Applying CCO to a work or any other type of protected subject matter:

"overtly, fully, permanently, irrevocably and unconditionally waives, abandons, and surrenders all of Affirmer's Copyright and Related Rights [including database rights] and associated claims and causes of action, whether now known or unknown (including existing as well as future claims and causes of action), in the Work (i) in all territories worldwide, (ii) for the maximum duration provided by applicable law or treaty (including

381 See: http://wiki.creativecommons.org/4.0/License_subject_matter (last accessed 06/2013).

382 See http:// creativecommons.org/about/cc0 (last accessed 06/2013). 
future time extensions), (iii) in any current or future medium and for any number of copies, and (iv) for any purpose whatsoever, including without limitation commercial, advertising or promotional purposes (the "waiver")383."

Consequently, anyone can use the information released under a CCO Dedication in any way and for any purpose - including commercial use. If the waiver is not effective or legally valid for any reason, $\mathrm{CCO}$ acts as a licence from the affirmer granting everyone an unconditional, irrevocable, non-exclusive, royaltyfree licence to use the work for whatever purpose. Especially in cases where the determination of the rights status of a database is difficult, CCO can be a useful tool for clarifying to the general public that the affirmer is committed to relinquishing protection to the broadest extent possible.

The strong position adopted in the past by Creative Commons towards the SGDR has left the field open for the elaboration of "competing" licences that specifically address the database right and its peculiarities, and also allowing for restrictions.

\subsubsection{Open Data Commons}

A more recent project in the realm of Open Access is the Open Data Commons (ODC) ${ }^{384}$ led by the Open Knowledge Foundation ${ }^{385}$. A set of three licences was launched between 2008 and 2010: the Public Domain Dedication and License (PDDL) ${ }^{386}$, the Attribution License (ODC-By), and the Open Database License (ODC-ODbL). Strongly inspired by the CC licences in their structure and wording, the ODC licences are designed to specifically provide for the licensing of databases and their contents, which are protected under copyright and the European sui generis database right. The licences are meant to cover all types of databases, whether produced by commercial entities, public sector institutions or anyone else. They are therefore not explicitly crafted to apply to scientific research results. The ODC licences are much less known or used than the CC licences. The

\footnotetext{
383 Article 2 of CC0 1.0 Universal further states that 'Affirmer makes the Waiver for the benefit of each member of the public at large and to the detriment of Affirmer's heirs and successors, fully intending that such Waiver shall not be subject to revocation, rescission, cancellation, termination, or any other legal or equitable action to disrupt the quiet enjoyment of the Work by the public as contemplated by Affirmer's express Statement of Purpose'.

384 See http://opendatacommons.org (last accessed 06/2013).

385 See http://okfn.org (last accessed 06/2013). The Open Knowledge Foundation is a non-profit organisation founded in 2004 and acts as one of the main international leaders in the promotion of open knowledge in many different forms.

386 Open Data Commons was created in December 2007 as a platform for the drafting of the first 'open' database licence, the Public Domain Dedication and License, which was written by Jordan Hatcher and Dr Charlotte Waelde. In January 2009 the Open Data Commons project was transferred to the Open Knowledge Foundation. The Foundation is in charge of the daily administration of the project, whilst its Advisory Council is responsible for the drafting and management of the licences. See http://opendatacommons.org/about (last accessed 06/2013).
} 
best-known "major adopter" is the OpenStreetMap project, which switched from a CC-By-SA to the ODbL due to the waiver of the database right under the CC licences 387 . In addition, the ODC licences are not provided in a "machinereadable" format, which makes it much more difficult to estimate their level of use. Be that as it may, and although not devoid of imperfections, all three ODC licences meet the Open Access principles of free accessibility, further distribution and proper archiving. The two later licences also guarantee proper attribution of the author or database maker.

The PDDL ${ }^{388}$ most closely resembles the CCO Dedication. The document is aimed at placing the database and its contents in or as close as possible to the public domain and is intended to apply to databases or their contents, either together or separately. It is intended to allow users to freely share (copy, distribute and use), create (produce derivative works from the database) and adapt (modify, transform and build upon) the work - meaning either or both the database (covered by copyright or the sui generis right) and its contents (defined as the "data" and including "information, independent works or other material collected into the database") - for any purpose and without any kind of restrictions, permanently and irrevocably. In fact, users can use the databases or their contents commercially and apply technical protection measures and they are required neither to attribute the creator of the data or database nor to provide further users with a copy of the licence. Should the relinquishment or waiver of rights not be valid in a particular jurisdiction, the PDDL document contains a fall-back licence, comparable to that of the CCO.

With respect to moral rights, the licence distinguishes between jurisdictions allowing such a waiver to the fullest extent possible and jurisdictions where such a waiver is not possible. That is the licensor "agrees not to assert any moral rights over the work and waives all claims in moral rights to the fullest extent possible by the law of the relevant jurisdiction". Remarkably, this licence, as well as the two others drawn up by Open Data Commons, makes no difference when dealing with moral rights between databases protected by copyright and by the sui generis right. Indeed, the traditional attributes of moral rights - including the right to object to derogatory treatment affecting the author's honour or reputation - are deemed to accrue exclusively with reference to copyright-protected databases, and commentators normally exclude moral rights from attaching to a database protected exclusively by virtue of a sui generis right ${ }^{389}$.

\footnotetext{
387 See: http://www.openstreetmap.org/copyright (last accessed 06/2013).

388 The full text of the PDDL document is available at: http://opendatacommons.org/licenses/pddl /1.0 (last accessed 06/2013).

389 See E. Derclaye, The Legal Protection of Databases. A Comparative Analysis, Cheltenham, Edward Elgar Publishing, 2008, p. 53; and the same commentator, 'Intellectual Property Rights and Human Rights: Coinciding and Cooperating', in P. Torremans (ed.), Intellectual Property and Human Rights, The Hague, Kluwer Law International, Information Law Series, 2008, p. 143.
} 
The second licence offered is the Open Data Commons Attribution License (ODC-By). As its name indicates, it closely resembles the CC-By License and is intended to allow users to share, modify and use the database freely, subject only to the attribution requirement. The preamble of the licence specifies that:

"Databases can contain a wide variety of types of content (images, audiovisual material, and sounds all in the same database, for example), and so this license only governs the rights over the Database, and not the contents of the Database individually. Licensors may therefore wish to use this licence together with another license for the contents."

Through the ODC-By the licensor grants a worldwide, royalty-free, non-exclusive licence to use the database for the duration of any applicable copyright and database rights, and explicitly allowing commercial exploitation. Among the rights granted, the following are mentioned: (a) extraction and re-utilisation of the whole or a substantial part of the contents; (b) creation of derivative databases ${ }^{390}$; (c) creation of collective databases ${ }^{391}$; (d) creation of temporary or permanent reproductions by any means and in any form, in whole or in part, including of any derivative databases or as part of collective databases; and (e) distribution, communication, display, lending, making available, or performance to the public by any means and in any form, in whole or in part, including of any derivative database or as part of collective databases.

Although the licence only governs the rights over the database, and not the contents of the database individually, its stated legal effect is to operate a licence of applicable copyright and neighbouring rights; a licence of the database right; and a contractual agreement between the user and the licensor. It is unclear, however, what role neighbouring rights could play in this context, given that the neighbouring rights that are part of the acquis communautaire concern the rights of performing artists, phonogram producers, film producers and broadcasting organisations. The grant of a licence on neighbouring rights is all the more odd as Article 2.4 of the licence specifies that:

"The individual items of the Contents contained in this Database may be covered by other rights, including copyright, patent, data protection, privacy, or personality rights, and this License does not cover any rights (other than Database Rights or in contract) in individual Contents contained in the Database. For example, if used on a Database of

\footnotetext{
${ }^{390}$ Section 1 containing the definitions specifies that 'derivative database' is intended as 'a database based upon the database, and includes any translation, adaptation, arrangement, modification, or any other alteration of the database or of substantial parts of the contents. This includes, but is not limited to, extracting and re-utilising the whole or a substantial part of the contents in a new database.'.

391 A 'collective database' corresponds to the licensed database in unmodified form as part of a collection of independent databases that together are assembled into a collective whole. The ODC-By License further specifies that a work which constitutes a collective database is not considered, under the terms of the licence, as a derivative database.
} 
images (the Contents), this License would not apply to copyright over individual images, which could have their own separate licenses, or one single license covering all of the rights over the images."

If a separate licence is necessary to cover the rights over the individual contents of the database, then why license neighbouring rights? Following the same questionable logic, moral rights are waived and extensive wording has been included to deal with (non-) waivable compulsory and/or voluntary licensing schemes. The fact is that nowhere in Europe are there any collective rights management schemes, mandatory or even voluntary, concerning rights in databases. This language can therefore only relate to the individual contents, which are not covered by the licence. Nevertheless, the ODC-By License contains a useful indication on how to give proper attribution. It also stresses that the licence is without prejudice to the exercise of any exception or limitation provided for in the law.

The third and last licence is the Open Database License (ODbL) ${ }^{392}$ Attribution and Share Alike for Data/Databases License. Like the ODC-By, the scope of application of the ODbL is somewhat unclear. The preamble states that:

"Licensors should use the ODbL together with another license for the contents, if the contents have a single set of rights that uniformly covers all of the contents. If the contents have multiple sets of different rights, Licensors should describe what rights govern what contents together in the individual record or in some other way that clarifies what rights apply."

The ODbL grants users (like the ODC-By) of the database a worldwide, royaltyfree, non-exclusive licence to use the database for the duration of any applicable copyright and database rights, and explicitly allowing commercial exploitation. The ODbL contains identical language to that of the ODC-By regarding neighbouring rights, moral rights and mandatory or voluntary licensing schemes.

Compared to the ODC-By, the ODbL contains an important additional condition of use, namely that licensees that make public use of any derivative database of the original database are required to do so (i) only under the terms of the ODbL, or, alternatively, (ii) according to a later version of the same licence equivalent to the spirit of the original one - or (iii) according to a (not-furtherspecified) compatible licence. If the original database or a derivative database is incorporated into a collective database, the licensee is not required to apply the ODbL to license the collective database; indeed, as defined in the ODbL, a collective database is not considered as a derivative database. Nevertheless, the licence still applies to the original database or to a derivative one as part of the collection.

\footnotetext{
392 The text of the human-readable summary and of the full text of the OdbL can be found, respecti vely, at the following links: http://opendatacommons.org/licenses/odbl/summary and http:// opendatacommons.org/licenses/odbl/1.0 (both last accessed 06/2013).
} 
Additionally, regarding the use of a derivative database or a work produced from a derivative database, the user is required to offer recipients of the derivative database or produced work a machine-readable copy of (i) the entire derivative database, or (ii) a file with all the modifications applied to the database or the methods for carrying out such alterations, including any additional contents between the original database and the derivative database.

Another notable difference from the ODC-By License is the presence of a specific provision on technological measures and additional terms, which are - in principle - forbidden and can only be imposed on the database, on the derivative database or on the whole or a substantial part of the contents (defined as a "restricted database") in the manner specified in the licence. This latter provision which admits a scheme resembling one of "dual-licensing" adopted for certain models of free software - states that such restrictions are applicable only if a copy of the original or derivative database is made available to the recipient (i) without additional fee, (ii) in a medium (defined as an "unrestricted database") that does not alter the terms of the licence or limit the possibility of any person to enjoy such rights and (iii) subject to the fact that the unrestricted database is at least as accessible to the recipient as the restricted database.

It can be argued that the structure of the ODbL and of its legal requirements together with the considerable length of the document itself - appears too complex for non-lawyers to understand and interpret without the advice of an expert, thus resulting in increased transaction costs. Since the ODbL incorporates a Share Alike element - providing that derivative works must be distributed under the terms of the same ODbL - problems can arise for users who want to combine data and works from different sources.

While in theory the ODC licences would seem perfectly adapted to license rights over research data and the database containing them, several aspects of the licences make their use less attractive. The main reason is that the licences only cover the database itself and not its contents. Therefore there is no possibility to license the whole by means of one instrument. For example, OpenStreetMap has licensed its database under the ODbL, but was forced to license its copyrightprotected maps under a CC By-SA license ${ }^{393}$. Should a research institution, an institutional repository or a publisher wish to license scientific publications together with the datasets upon which the publications are based, then it would need to use two distinct licences, one for the database and one for its content. This duality of instruments is at best unpractical, but at worse liable to lead to confusion and incompatibilities.

\footnotetext{
393 See: http://www.openstreetmap.org/copyright (last accessed 06/2013).
} 


\subsubsection{Digital Peer Publishing Licence (DPPL)}

Contrary to the CC and the ODC licences, the Digital Peer Publishing Licence (DPPL) was crafted specifically with scientific publications in mind ${ }^{394}$. The licences were developed between 2004 and 2008 on commission of the Ministry of Innovation, Science, Research and Technology of the state of North-Rhine Westphalia in Germany by two German scholars Prof. A. Metzger and Dr T. Jaeger of the Institut für Rechtsfragen der Freien und Open Source Software (IfrOSS) (Institute for Legal Issues on Free and Open Source Software) ${ }^{395}$. The DPPL is designed for scholarly content because it covers aspects of authenticity, citation, bibliographic data and metadata, permanent access and open formats. The DPPL is not very well known outside Germany, but nevertheless will be discussed as an example of a more exotic licence to be used. Through the DiPP project sponsored by the state of North-Rhine Westphalia just under 20 electronic journals are published under the terms of the DPPL. There might be other users who are less easily traceable.

The DPPL is offered in three modules: the DPPL (akin to the CC-By-ND License), the free DPPL (akin to the CC-By License) and the modular DPPL. The modular DPPL allows the rights holder to restrict the possibility of the user to make unauthorised modifications only to those parts of the publication that are indicated as such by the rights holder. In so far as all three licences specifically refer to the Berlin Declaration in their preamble, all meet the Open Access principles of free accessibility, further distribution and proper archiving. All licences also guarantee proper attribution of the author and one iteration allows the full control of the integrity of the original work.

The basic module allows all documents to be read and distributed unchanged by everybody or accessed for downloading. There is no distinction made between scientific or commercial use. Because document can be delivered only in electronic format under this licence, no rights concerning a printed version or a version on storage media are covered. Thus electronic distribution is promoted. On the other hand, the bearer of the rights still has the option to contract with a publisher in respect of other versions of his work for commercial distribution, if desired:

"This license agreement shall, unrestricted by time and place, allow You to reproduce the Work in electronic form and to pass the Work on to third parties by electronic means, e.g. by e-mail communication, and - particularly by making it available for downloadto make it publicly accessible. The license shall comprise all types of use of the work that encompass non-physical reproduction or conveyance of the Work, whether already known

\footnotetext{
394 See: http://www.dipp.nrw.de/lizenzen/dppl/mdppl/m-DPPL_v3_en_11-2008.html (last accessed 06/2013).

395 See: http://www.ifross.org (last accessed 06/2013).
} 
or unknown at the time of conclusion of this license agreement. Use in physical form, particularly the distribution of printed Works, and the Use of Altered Versions of the Work shall not be permitted."

The extended modules of the licence are designed for sharing and reuse of published material. The "modular DPPL" and the "free DPPL" allow users to change published material and explain how to cite properly if changes are made. In the modular DPPL, changes may only be performed for some parts of the content. This makes it possible, for example, to fix the text while images may be changed. In the free DPPL, anything in the publication may be changed pursuant to the terms of the licence. As the explanatory document to the licences states:

"Scientific researchers are regularly interested in making their findings widely available at a high level of quality. The Modular DPPL Licence therefore permits the passing on of copyrighted material. It furthermore grants permission to modify those parts of a work, marked as alterable by the authors and allows the dissemination of altered versions. While this rule intends to facilitate collaboration between scientists, it leaves the decision up the author, to open only certain parts of his work for interactive scientific collaboration. The aim of this Modular DPPL Licence is to ensure that this process takes place in a fair, transparent and secure way for all those involved."

All three iterations of the DPPL are well crafted and balanced. Therefore, they would in principle suit the licensing needs of scientific institutions very well, were it not for the fact that none of the licences seem to cover anything other than copyright-protected publications. In so far as "Work" under all three licences is defined as "The work protected by copyright, to which the rights to Use are granted by this licence agreement", it is highly unlikely that the licences can be interpreted to apply to databases and datasets as well. 


\section{Conclusions and Recommendations}

In the following, we will briefly describe the conclusions of our study on the European legal framework and thereafter give some recommendations on how the rights situation as to research data can be improved. The focus will be on the interests of the scientific community as well as on the aspect of legal security. Some recommendations will be given to the European legislator on how to improve the European regulations. In addition, specific recommendations on how to enable the use and reuse of research data between repositories/data providers and e-infrastructure providers on a contractual basis will be given.

\subsection{Conclusions on the legal framework}

Taking into account the legal framework referred to above, whether on the level of Acts and directives or on the contractual level of licences, some major pitfalls are obvious which can be structured along the lines of the intended mutual recognition and use of research data and databases. Before analysing these pitfalls and giving some recommendations we highlight briefly the results of the legal analysis:

a) Research data itself is not protected by copyright law and seldom by other legal norms. Only databases and their structures are protected (if sufficient investments have been undertaken for establishing the database).

b) (Massive) extraction of data for the purpose of analysis is not being covered by specific limitations and exceptions of the Database Directive such as the limitations for temporary copies enshrined in Article 5(1) Info Directive.

c) Scientific use of databases is just an optional limitation (Article 9 Database Directive) and is not fully harmonised. Hence, the scope of this limitation is quite opaque across the different Member States.

d) Scientific use does not cover the electronic infrastructure as such. Hence, the entire reproduction of a database cannot be justified by scientific use. The envisaged reproduction of other databases in OpenAIREplus and vice versa is thus not being covered by the limitations.

e) Specifically, only direct scientific use is being covered by the limitations of the Database Directive. Hence, indirect scientific use, such as scientific databases using another database, cannot benefit from the limitations. 
f) Moreover, linking to research data and/or publications is not clearly regulated either in the Info Directive or in the Database Directive. Obviously, some Member States have the tendency to qualify linking as another way of making works publicly available, thus burdening the link setter with the obligation of obtaining specific licences/agreements of the author. However, an ECJ decision could clarify these issues in the near future.

On the level of licences some deficits have also appeared:

a) As demonstrated, the Creative Commons License version 3.0 explicitly does not cover database rights as they are reserved in the case of the unported version and waived in the case of the EU ported versions.

b) Other licences such as the ODC Licences suffer from a lack of interoperability with machines and do not cover specific scientific purposes or they do not refer to copyrights as well as to database rights so that different licences have to be used.

c) Even carefully crafted licences such as the German DPPL do not deal with database rights explicitly. Moreover, these national licences are scarcely known outside the relevant Member State, here Germany.

Given these deficits a set of actions may be considered that could be structured roughly according to the different roles/levels of actors: be it legislation or be it contractual.

\subsection{Recommendations to the European legislator}

Legislative actions should be considered only on the European level due to the fact that the relevant legal acts are harmonised by European directives. Thus, there is scarcely any leeway for national legislators to introduce new limitations; however, new protection rights may be created, such as the recent new right for press publishers in Germany ${ }^{396}$.

This fact points to the first question to be answered, namely whether there is a need for protecting research data, e.g. by introducing a new sui generis right. Starting with the idea that research data should be freely (re-)usable by the scientific community, such a new right would be highly counter-productive to the envisaged goal as it allows other (scientific) users to be blocked from analysing and using the data. Such a protection right to data would encompass any kind of data that could be created, such as meteorological data, health data, traffic data etc. A definition

\footnotetext{
${ }^{396}$ BGBl. 2013 I Nr. 23, S. 1161; cf. Also M. Stieper, 'Das Leistungsschutzrecht für Presseverleger nach dem Regierungsentwurf zum 7. UrhRÄndG', ZUM 2013, 10; J. Ensthaler and H. Blanz, 'Leistungsschutzrecht für Presseverleger', GRUR 2012, 1104.
} 
of research data is hard to find ${ }^{397}$. Thus, the sensitive balance between freedom of access to ideas and to data etc. on one side and protection for works on the other side would be heavily affected. Hence, any kind of protection of data should be restricted to privacy law and contractual provisions (such as know-how protections), if any.

More relevant to the OpenAIREplus concept would be the introduction of new limitations for scientific use of databases: starting with the limitation for scientific purposes enshrined in Article 9(a) Database Directive, the scope of privileged uses should be enlarged, explicitly encompassing the analysis, the re-utilisation and the whole reproduction of a database. However, only use for scientific purposes as well as intermediary scientific purposes such as noncommercial scientific databases should be privileged. By enlarging the scope of privileged users to infrastructure operators such as non-commercial scientific databases, the barriers to exchange data and also metadata could be overcome. Moreover, the right to make the data (and database) available to the public on a non-commercial-use basis should be integrated as well, as it is not actually subject to the limitations for scientific purposes.

At least the limitations of Article 9(a) of the Database Directive should be made mandatory and be crafted in such a way that the limitation is a full harmonisation.

\subsection{Recommendations to data- and e-infrastructure providers}

However, these legal options may come too late to enhance research in the EU as it has proved to be very difficult from a political angle to reform EU directives in IP rights. Hence, in order to foster the OpenAIREplus e-infrastructure it is highly recommended that a contractually based framework for open exchange of data and databases be established. As these networks encompass potentially vast number of participants it could be based only upon the type of Open Source/Open Access/Creative Commons licences, which require the user to use the same type of licences in order to benefit from the rights transferred, thus ensuring the spreading of the licence and the boosting of exchange on the same grounds ${ }^{398}$.

From this starting point the choice is easily made: given the pitfalls of the licences described, such as ODC etc., and taking into account the recent reforms of the Creative Commons Licence it is clear that the new CC License version 4.0 is the most suited to the purposes of the OpenAIREplus project. As the new CC Licence now encompasses database rights as well as copyrights it guarantees the

\footnotetext{
${ }^{397}$ Cf. Chapter 1 above.

398 Thus, it is no wonder that some legal scholars even qualified Open Source Systems as a sort of partnership, constituted by a subsequent agreement to the same licence.
} 
free exchange of research data, albeit on condition that users follow the same approach. Thus, it is ensured that a commercial exploitation of non-commercial databases is excluded and a free flow of information is guaranteed.

During the development of the OpenAIREplus project, thanks to the collaboration between the different teams involved, and especially the scientific teams collaborating on Working Package 3 and the legal team, a list of databases has been gathered that will be used for the OpenAIREplus project ${ }^{399}$. The list is not complete and never will be, given the ambition of scalability of OpenAIREplus.

However, it proves to be a very useful element for an exercise of analysis and understanding of how to implement legal research at the level of the databases used by OpenAIREplus.

Of the 19 listed databases, none currently fulfils the conditions of Open Access $^{400}$. A structural absence of legal expertise in the specific field of regulation of the copyright and related rights aspects deriving from the use of the databases of the participating partners can generally be observed. The lack of expertise and of specific legal competences is particularly serious, especially in light of the fact that in a few cases a sensibility towards Open Access goals is clearly present and can be identified in the terms of use with expressions such as: "the data are freely available", "the system is operated in the sense of the Berlin Declaration on Open Access", or even references to a Creative Commons licence, unfortunately without an indication of the correct licence, for the reference is to the 3.0 unported version, which is, as we have seen above, a version that does not license the sui generis right on databases.

The consequences of this lack of clear Open Access conditions are serious. A lack of Open Access in this context means that no reuse, mining or other forms of analysis of contents of databases are in accordance with the terms of use of the databases used. Therefore, the OpenAIREplus infrastructure is not effectively authorised to use the partners' databases as intended.

The fact that often at least a general indication of the "Open Access ideals" behind the database is given does not help much. To state that a database is available in "the sense of the Open Access" movement offers an idea of what the purpose of the developers is; it could give guidance to a court in the case of litigation, but not the legal certainty necessary in these cases to avoid possible liability. The use of specific references, such as to a Creative Commons License, is once again not sufficient. On the contrary, as we have seen, the reference is often made to the wrong licence, in a way that will offer no possibility of different interpretation. The databases are often made available under a licence that reserves the SGDR to its maker; therefore any unauthorised use - such as acts of data mining - is in violation of the terms of use and will give rise to liability. The common-sense

\footnotetext{
399 Thanks to Jochen Schirrwagen, Maarten Hoogerwerf and Johanna Mcentyre for facilitating such list.

${ }^{400}$ For more details about Open Access see above Chapter 4.1.
} 
argument that, within the OpenAIREplus project, the owner of the database will never pursue such a course is a weak one, since it is precisely when rights are allocated with uncertainty, when the owners of such rights change, or when the project's dimensions or initial conditions are subject to significant changes, that the importance of having drafted the proper contractual agreement and allocated property rights with precision becomes fundamental.

The situation is serious but not irremediable. It is advisable to urgently change the terms of use of the databases of OpenAIREplus and its partners to include a reference to the correct licences. We have analysed some of the best examples of Open Access licences and we have also stated our preference, for the reasons explained above, for the upcoming version 4.0 of the Creative Commons licences. Until the final version 4.0 is available, version 3.0 ported to EU legislation dealing with the SGDR is an acceptable solution. In such latter case, however, one has to bear in mind that the SGDR is waived, therefore no conditions, attribution, Share Alike, or any other condition will be applicable to the reuse of the database. Such reuse will, nonetheless, be legitimate.

Additionally, it is fundamental that the databases used by OpenAIREplus are made available under such licences in their entirety, therefore not only the data but the databases themselves. Only in these circumstances will activities such as data mining of the entire databases and reproduction of their contents be in accordance with the licences employed.

One of the objectives of OpenAIREplus is to become a reference model and infrastructure for the European scientific community and for European society in general, and in view of this, OpenAIREplus cannot be limited to a predetermined number of repositories. However, the inclusion of any new repository will have to be undertaken following the instructions given above, and we would strongly recommend that dedicated personnel with specific legal expertise in the field of copyright and related rights and in Open Access models be employed for this purpose. Only a case-by-case analysis of the newly added repositories can guarantee the avoidance of legal risks in including the wrong repositories. With the backup of this study, this is, however, a task that would be both feasible and gratifying. 
This study addresses the most important legal issues when implementing an open access e-infrastructure for research data. It examines the legal requirements for different kinds of usage of research data in an open access infrastructure, such as OpenAIREplus, which links them to publications. The existing legal framework regarding potentially relevant intellectual property (IP) rights is analysed from the general European perspective as well as from that of selected EU Member States. Various examples and usage scenarios are used to explain the scope of protection of the potentially relevant IP rights. In addition different licence models are analysed in order to identify the licence that is best suited to the aim of open access, especially in the context of the infrastructure of OpenAIREplus. Based on the outcomes of these analyses, some recommendations to the European legislator as well as data- and e-infrastructure providers are given on improving the rights situation in relation to research data. 